ALESSANDRA MARIANE KNOPIK BELTRAME

\title{
MAPEAMENTO DA COBERTURA DO SOLO AO LONGO DA FAIXA DE DOMÍNIO DE TREM METROPOLITANO: LINHA F EM SÃO PAULO
}

\author{
Dissertação de Mestrado \\ apresentado à Escola Politécnica \\ da Universidade de São Paulo \\ para obtenção do título de Mestre \\ em Engenharia de Transportes.
}


ALESSANDRA MARIANE KNOPIK BELTRAME

\title{
MAPEAMENTO DA COBERTURA DO SOLO AO LONGO DA FAIXA DE DOMÍNIO DE TREM METROPOLITANO: LINHA F EM SÃO PAULO
}

\author{
Dissertação de Mestrado \\ apresentado à Escola Politécnica da \\ Universidade de São Paulo para \\ obtenção do título de Mestre em \\ Engenharia.
}

Área de Concentração: Engenharia de Transportes Sub-área: Informações Espaciais

Orientador:

Professor Livre Docente José Alberto Quintanilha 
Este exemplar foi revisado e alterado em relação à versão original, sob responsabilidade única do autor e com a anuência de seu orientador.

São Paulo, 12 de setembro de 2008.

Assinatura do autor

Assinatura do orientador

FICHA CATALOGRÁFICA

Beltrame, Alessandra Mariane Knopik

Mapeamento da cobertura do solo ao longo da faixa de domínio de trem metropolitano : linha F em São Paulo / A.M.K.

Beltrame. - ed. rev. São Paulo, 2008.

$104 \mathrm{p}$.

Dissertação (Mestrado) - Escola Politécnica da Universidade de São Paulo. Departamento de Engenharia de Transportes.

1.Sensoriamento remoto 2.Geoprocessamento 3.Uso do solo 4.Transporte ferroviário I.Universidade de São Paulo. Escola Politécnica. Departamento de Engenharia de Transportes II.t. 
Ao meu filho Stefano, não sei se o mundo é bom, mas ele ficou melhor desde que você chegou" 


\section{AGRADECIMENTOS}

O desenvolvimento deste trabalho contou com a preciosa colaboração de pessoas e entidades, às quais expresso os mais sinceros agradecimentos.

Ao Conselho Nacional de Desenvolvimento Cientifico e Tecnológico - CNPq, pelo apoio oferecido.

Ao Prof. Dr. José Alberto Quintanilha - orientador deste trabalho - pela confiança em mim depositada e pelas oportunidades de crescimento profissional oferecidas ao longo destes últimos anos. Agradeço ainda por suas críticas sugestões e direcionamentos imprescindíveis à realização desta dissertação.

Aos professores do Marcos Rodrigues, Denizar Blitskow, Nicola Paciléo e Homero Fonseca Filho, tão importantes na aquisição de novos conhecimentos para a condução deste trabalho.

À EPUSP pelo apoio institucional no desenvolvimento acadêmico-científico.

Ao PEA (Departamento de Engenharia de Energia e Automação Elétricas), em especial Maurício Jardini, pela oportunidade de trabalharmos juntos no projeto que deu origem a este.

À Diana Sarita Hamburger, pelo incentivo, confiança e permanente disposição em ajudar e discutir soluções.

Á Rosangela Leal e Jun Shinohara, pela constante ajuda e companheirismo. A amizade e apoio de vocês foram, e são, imprescindíveis.

Aos amigos do Labgeo, pelo companheirismo que juntos desenvolvemos, o que tornou esse caminho muito mais prazeroso, em especial a Mari, Rodrigo, Joana, Pati, Leonardo, Arlete, Alfredo, Olga, Cláudia e Ronaldo.

Aos amigos Emerson Mafra, Márcia Zubko e Erica Prado, verdadeiros companheiros de uma vida.

Aos meus pais, que me ensinaram deste cedo a valorizar o estudo, e em especial à minha mãe: quando eu crescer quero ser igual a você.

Ao Fabio e Stefano Beltrame, os homens da minha vida. 
Lá vai o trem com o menino Lá vai a vida a rodar Lá vai ciranda e destino Cidade e noite a girar

Lá vai o trem sem destino Pro dia novo encontrar Correndo vai pela terra Vai pela serra, vai pelo mar

Cantando pela serra do luar Correndo entre as estrelas a voar No ar... no ar...

(Trenzinho Caipira, Ferreira Gullar) 


\section{RESUMO}

O transporte ferroviário de passageiros ganha importância estratégica na melhoria do trânsito e qualidade de vida dos grandes centros urbanos, mas no Brasil enfrenta sérios problemas operacionais, como obsolescência da infra-estrutura e invasão da faixa de domínio, comprometendo sua segurança e operacionalidade. $O$ objetivo central deste trabalho é o mapeamento da cobertura do solo ao longo da faixa de domínio de uma linha de trem metropolitano. A área de estudo concentra-se nas adjacências da Linha F de trem metropolitano de São Paulo, operada pela CPTM Companhia Paulista de Trens Metropolitanos, com 38,8 km de extensão, cruzando as zonas central e leste da capital paulista, estendendo-se até outros municípios da Grande São Paulo. A metodologia adotada compreende 0 uso de imagem de satélite de alta resolução espacial IKONOS II, e técnica de classificação baseada em regiões. Os classificadores por regiões utilizam, além de informação espectral de cada pixel, a informação espacial que envolve a relação entre os pixels e seus vizinhos. Através da interpretação visual, foram identificadas doze classes de coberturas do solo, cujas feições nortearam os parâmetros da segmentação. A imagem segmentada foi então classificada usando o algoritmo de Bhattacharyya e pós-classificada utilizando regras e critérios definidos para cada classe, de acordo com seus atributos e contextualização. O desempenho da classificação final foi avaliado com base no coeficiente Kappa tendo atingido nível aceitável de correspondência. O mapa de cobertura do solo gerado a partir da classificação, demonstra que o entorno da linha é composto, predominantemente, por materiais impermeáveis - como asfalto e concreto - mas possui presença significativa de elementos naturais - como vegetação e água. Desta forma, comprova-se a aplicabilidade de imagem de satélite de alta resolução e técnicas de processamento de imagem como suportes ao planejamento e gerenciamento do entorno da ferrovia. 


\section{ABSTRACT}

The rail transport of passengers has strategic importance in the traffic and quality of life improvement in the downtowns, but in Brazil it faces serious operational problems such as obsolete infrastructure and invasion of the right of way, compromising its safety and operability. The principal aim of this paper is the mapping of land cover area of metropolitan railway right of way. The study focuses on the outskirts of the Line $F$ metropolitan train in Sao Paulo, operated by CPTM - Companhia Paulista de Trens Metropolitanos, with $38,8 \mathrm{~km}$ long, crossing the central and eastern areas of São Paulo, extending to other cities in the Metropolitan Region of Sao Paulo. The methodology includes the use of the high spatial resolution satellite image IKONOS II, and regions-based classification. The regions-based classifiers use, besides spectral information of each pixel, the spatial information that involves the relationship between the pixels and its neighbours. Through visual interpretation, were identified twelve classes of land covers, which features guided the segmentation parameters. The segmented image was classified using Bhattacharyya distance and post-classified using rules and criteria established for each class, according to their attributes and contextualization. The performance of the final classification was evaluated based on Kappa coefficient, resulting acceptable level of correspondence. The mapping of land cover generated from the classification, shows that the outskirts of the metropolitan railway`s right way is predominantly composed by impermeable materials - such as asphalt and concrete - but has significant presence of natural elements - such as vegetation and water. Thus, is evident the applicability of high spatial resolution satellite image added to classification methods for remotely sensed data for planning and management of the railway right of way. 
SUMÁRIO

\section{AGRADECIMENTOS \\ RESUMO \\ ABSTRACT}

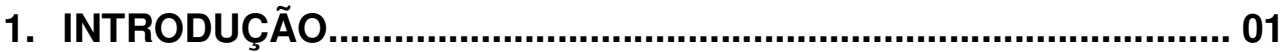

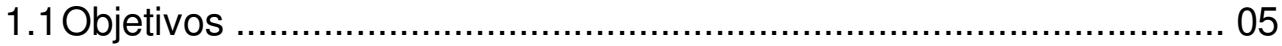

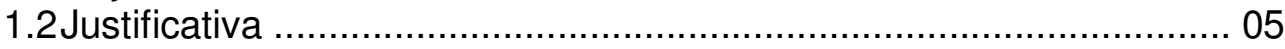

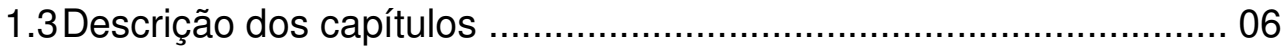

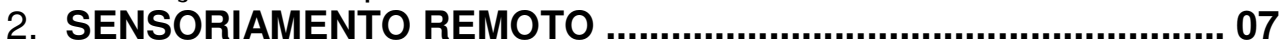

2.1 Comportamento espectral ..................................................... 08

2.1.1 Comportamento espectral das superfícies construídas ................ 11

2.1.2 Comportamento espectral da vegetação ................................... 12

2.1.3 Comportamento espectral do solo ........................................ 15

2.1.4 Comportamento espectral da água......................................... 16

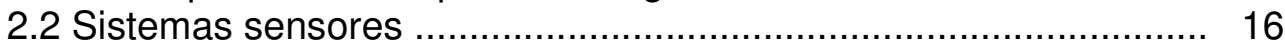

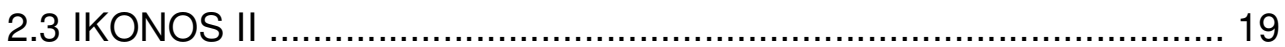

2.4 Identificação do uso e cobertura do solo ........................................ 20

2.5 Aplicações na área de transporte ............................................... 25

2.5.1 Análise ambiental .......................................................... 26

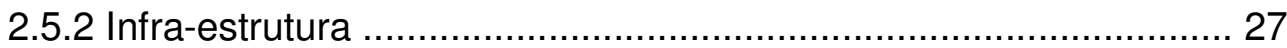

3. PROCESSAMENTO DIGITAL DE IMAGENS …........................... 29

3.1 Sistema de interpretação de imagem ............................................... 29

3.2 Processamento digital de imagens ……………........................... 35

3.2.1 Classificadores tradicionais .................................................... 36

3.2.2 Classificação supervisionada …………………...................... 36

3.2.3 Classificação não-supervisionada ........................................... 40

3.2.4 Limitações dos classificadores tradicionais ………….......... 41

3.2.5 Classificação por regiões ...................................................... 42

3.2.6 Segmentação .................................................................. 43

3.4 União de dados de Sistema de Informação Geográfica - SIG e sensoriamento remoto ................................................................. 45

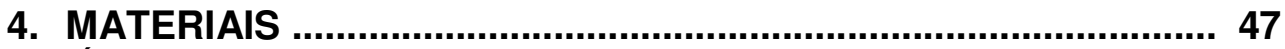

4.1 Área de abrangência total da pesquisa ..................................... 47

4.2 Linha F ........................................................................ 49

4.3 Imagem de satélite ............................................................ 50

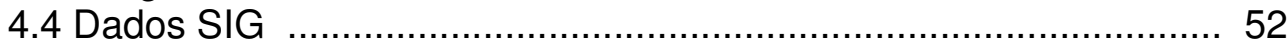

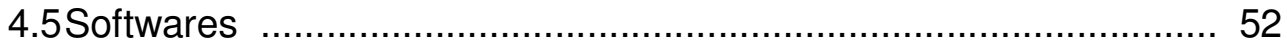

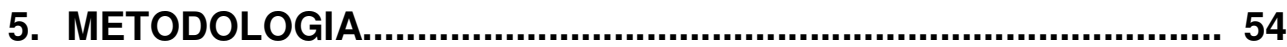

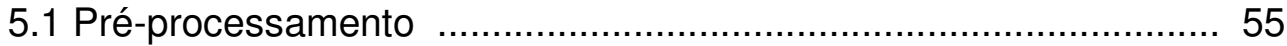

5.2 Definição da área de estudo ………………………………..... 57

5.3 Processamento digital ........................................................... 59

5.3.1 Definição das classes de objeto ............................................. 59

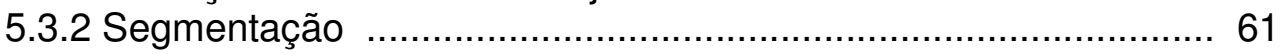

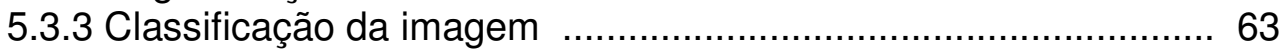

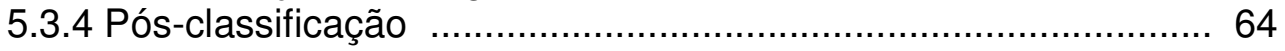

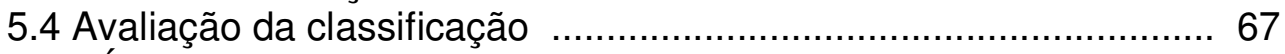

5.4.1 Índices de avaliação ……........................................................ 69 


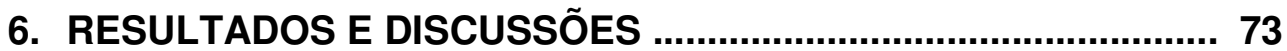

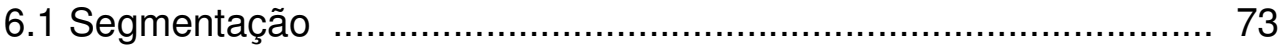

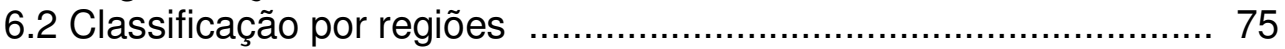

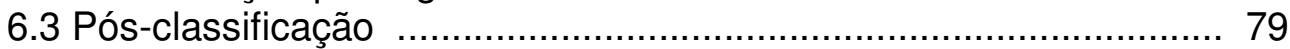

6.3.1 Análise dos resultados preliminares ………………................ 81

6.3.2 Critérios de reclassificação ……………………..................... 81

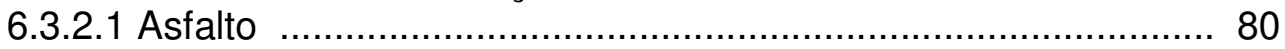

6.3.2.2 Solo exposto médio e telha cerâmica ……………………….... 83

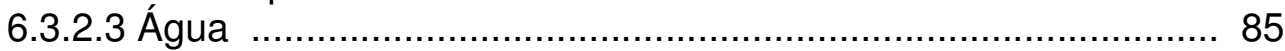

6.3.2.4 Vegetação densa .......................................................... 87

6.3.2.5 Cobertura metálica ………………………………........ 88

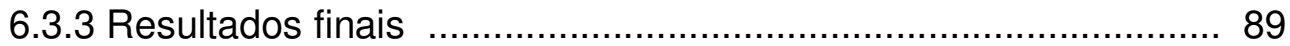

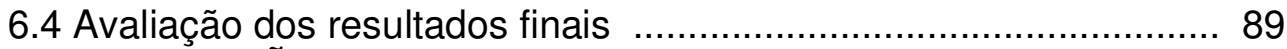

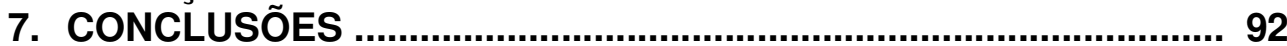

7.1 Recomendações para trabalhos futuros ……………………........ 93

REFERÊNCIAS BIBLIOGRÁFICAS ............................................. 95 


\section{LISTA DE FIGURAS}

Figura 01. Faixas do espectro eletromagnético ……................................ 08

Figura 02. Curva de reflectância espectral de alguns materiais ................... 10

Figura 03. Comportamento espectral de áreas não vegetadas .................... 11

Figura 04. Comportamento espectral de alvos urbanos ............................ 12

Figura 05. Sensoriamento remoto no contexto de demanda de informação na área de transporte .......................................................................... 25

Figura 06. Exemplo de distribuição de DN de um determinado pixel em quatro bandas espectrais.................................................................. 29

Figura 07. Exemplo de imagem do satélite WorldView-1........................... 31

Figura 08. Imagem IKONOS II da região agrícola de Campinas ............... 31

Figura 09. Imagem do satélite Resourcesat-1 da região de Foz do Iguaçu

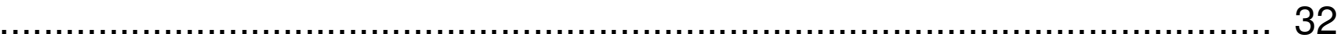

Figura 10. Imagem IKONOS II da zona residencial de Brasília .................. 33

Figura 11. Imagem de área agrícola caracterizando a presença de pivôs de irrigação ...................................................................................... 34

Figura 12. Classes no espaço de atributos ............................................. 35

Figura 13. Esquema básico da classificação supervisionada ..................... 37

Figura 14. Esquematização da classificação pelo método do paralelepípedo

Figura 15. Esquematização da classificação pela mínima distância ......... 39

Figura 16. Esquematização da classificação pela máxima verossimilhança

Figura 17. Exemplos de relaccões topológicas entre áreas

Figura 18. Esquematização das linhas de transporte metroferroviário em São

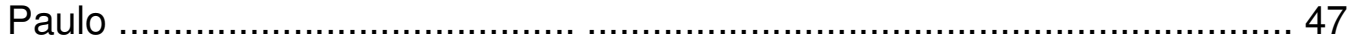

Figura 19. Localização da área de estudo, no detalhe a linha F.................. 48

Figura 20. Área de estudo com informações sobre a Lei de Zoneamento e características demográficas ................................................................... 49

Figura 21. Cobertura das imagens Íkonos II sobre a RMSP ...................... 51

Figura 22. Sobreposição das bases digitais de Quadra (vermelho) e Logradouro (azul) na imagem IKONOS num pedaço da área de estudo

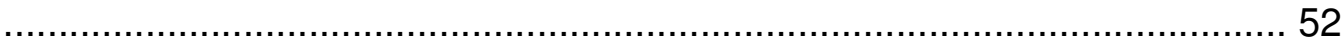

Figura 23. Esquema da metodologia proposta ....................................... 54

Figura 24. Estrutura das folhas da coleção de imagens e as respectivas informações de órbita e data de captura da imagem IKONOS II

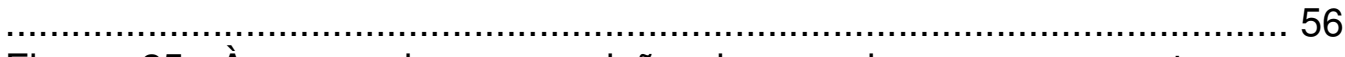

Figura 25. À esquerda, composição do mosaico com as quatro cenas necessárias para cobertura parcial da Linha F; à direita cenas já mosaicadas e balanceadas ........................................................................... 57

Figura 26. Composição RGB das quatro cenas selecionadas com a sobreposição de um trecho da Linha F ................................................ 58

Figura 27. Delimitação da área de teste, compreendendo $750 \mathrm{~m}$ ao redor da linha de trem ............................................................................... 59

Figura 28. Acima, imagem detalhada de um pedaço da área. Abaixo, a mesma imagem com a segmentação das feições ......................................... 63 
Figura 29. Sobreposição dos vetores de quadras (vermelho) e logradouros (azul) em relação à imagem antes do ajustes ..........................................6 65

Figura 30. Sobreposição dos vetores de quadras (vermelho) e logradouros (azul) em relação à imagem após o ajuste

Figura 31. Acima exemplificação do NDVI gerado e abaixo a mesma área com a imagem original

Figura 32. Área teste inserida no contexto da área do projeto e abaixo a área teste em detalhe com vetor de segmentação sobreposto

Figura 33. Típica matriz de confusão 70

Figura 34. Acima, extensa área de vegetação e elevado número de segmentos; abaixo, área de construção irregular e de baixa dimensão, mas bem delimitada 74

Figura 35. Resultado da classificação por regiões na área de estudo ......... 76 Figura 36. Exemplificação da confusão verificada entre algumas classes... 77 Figura 37. Resultado da classificação por regiões, destacando a presença de determinadas feições, como eixo de ruas, telhados e áreas verdes

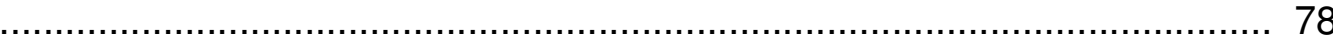

Figura 38. Classificação final ............................................................. 89

Figura 39. Duas cenas com maior nível de detalhamento, onde 1a e 2a correspondem à primeira classificação e $1 b$ e $2 b$ correspondem à classificação final 


\section{LISTA DE QUADROS}

Quadro 01. Principais regiões ou intervalos espectrais usados em sensoriamento remoto

Quadro 02. Fórmula dos índices de vegetação do vermelho e infravermelho

próximo

Quadro 03. Principais características do sensor IKONOS II .................... 19

Quadro 04. Adaptação do Sistema USGS de classificação do uso e cobertura do solo

Quadro 05. Sistema CORINE para classificação da cobertura do solo

Quadro 06. Discriminação das cenas utilizadas no projeto

56

Quadro 07. Classes identificadas na imagem com algumas de suas

características 


\section{LISTA DE TABELAS}

Tabela 01. Matriz de confusão da classificação por regiões.......................... 79

Tabela 02. Matriz de erro após aplicação de ajuste para classe asfalto $\ldots 82$

Tabela 03. Matriz de erro após aplicação de ajuste para classe asfalto e solo exposto médio

Tabela 04. Matriz de erro após aplicação de ajuste para classe asfalto,solo exposto médio e telha cerâmica 85

Tabela 05. Matriz de erro após aplicação de ajuste para classe asfalto,solo exposto médio, telha cerâmica e água 86

Tabela 06. Matriz de erro após aplicação de ajuste para classe asfalto, solo exposto médio, telha cerâmica, água e vegetação densa 88

Tabela 07. Matriz de erro sobre a qual foi calculado o coeficiente Kappa tradicional 


\section{INTRODUÇÃO}

O uso de trens intermunicipais para transporte de passageiros intensificou-se em diversos países, nas últimas três décadas, motivado por fatores como segurança, rapidez, economia e redução de impactos negativos ao meio ambiente. Contrariamente no Brasil, o transporte ferroviário de passageiro sofreu forte declínio, estando muito próximo da extinção, ao ser substituído por frotas de ônibus.

Passados mais de 150 anos da inauguração da primeira estrada de ferro no país, o transporte ferroviário retorna à pauta de discussões como alternativa de eficiência e redução de custos para o transporte de cargas e de passageiros, impulsionando o crescimento econômico do país.

O transporte ferroviário no Brasil teve seu início com inauguração da Estrada de Ferro Mauá - localizada no estado do Rio de Janeiro, entre o Porto de Estrela, ao fundo da Baía da Guanabara e a localidade de Raiz da Serra, em direção à cidade de Petrópolis, em 1854, (DNIT, 2008) pela qual circulou também o primeiro trem de passageiros. Conforme Silva (2005), a implantação das ferrovias nas últimas décadas do século XIX visava o transporte de cargas e passageiros em grandes escalas por trajetos de média e longa distância. No Brasil, entretanto, as ferrovias foram implantadas com o objetivo principal de escoar a produção nacional, em especial a de café - até por isso foram construídas predominantemente em áreas rurais. Todavia, a instalação de estradas de ferro acabou promovendo também o transporte de passageiros.

Conforme Luz (2006), dezenas de grandes e médias cidades paulistas nasceram nos nós da rede ferroviária que corta o estado. Nelas o sistema viário tinha apenas serventia local, sendo a ferrovia o elemento de articulação da cidade e, às suas margens e nas proximidades de suas estações, é que o comércio apareceu, os serviços se instalaram e a cidade se ampliou.

O elevado fluxo de imigrantes estrangeiros para o interior de São Paulo, bem como viagens diárias de homens de negócio a Santos e à região 
portuária, ocasionaram o povoamento e a ocupação do espaço, atraindo para as margens das ferrovias o estabelecimento de atividades comerciais. As viagens diárias justificavam-se, no entender de seus viajantes, pelo fato de Santos ser um excelente centro econômico-comercial, mas uma região insalubre para se viver (CARVALHO, 1980).

Ainda segundo Carvalho (1980), quando o transporte rodoviário apresentou suas tentativas iniciais de concorrência, a preferência dos usuários permaneceu junto às ferrovias. De forma a garantir sua participação no mercado, a São Paulo Railway passou a substituir seus trens a vapor, popularmente conhecidos como "maria-fumaça", por composições dieselelétricas, denominadas "cometa", "planeta" e "estrela", reduzindo o tempo de viagem de 160 para 100 minutos no trajeto São Paulo - Santos. Destaca-se o depoimento de ferroviários que viveram essa fase: "Se a ferrovia tivesse conservado o mesmo padrão de serviço dos trens "cometa", o passageiro nunca trocaria a ferrovia pelo transporte rodoviário."

Contudo, além da concorrência cada vez mais forte do transporte rodoviário, as próprias companhias de trem foram, paulatinamente, focando seus interesses no transporte de cargas, em detrimento do de passageiros. Para tanto, alegavam que os trens de passageiros eram deficitários, com horários e trajetos certos a serem cumpridos, independente do percentual de ocupação, além de exigirem uma estrutura de atendimento que os tornariam pouco atraentes. Da mesma forma, um vagão de carga não possui horário certo para sair ou chegar, podendo ficar ocasionalmente detido numa estação ou desvio, sem maiores conseqüências.

Nas décadas subseqüentes a 1930, quando o país contava com $32.478 \mathrm{~km}$ de malha ferroviária, por motivos políticos e econômicos, o Brasil optou pela priorização do modelo rodoviário, em detrimento do ferroviário, impulsionando o crescimento econômico e alterando a dinâmica de deslocamento das pessoas. Em 1957 a Lei 3.115 criou a RFFSA - Rede Ferroviária Federal Sociedade Anônima, estabelecendo, com a devida delegação da União, o saneamento das perdas financeiras acumuladas pelas ferrovias administradas pelo poder público. 
Conforme Castro (2002), a desestatização do sistema ferroviário teve início na década de 80, marcada pelo Decreto-lei 2.178, de 1984, que, entre outras coisas, lançou as bases para a criação da CBTU - Companhia Brasileira de Trens Urbanos, que passou a se responsabilizar pelo transporte ferroviário de passageiro de subúrbio, atribuição até então conferida à RFFSA. Em 1992, a RFFSA foi incluída no Programa Nacional de Desestatização, marcando a separação do transporte de carga e de passageiros, a absorção por parte da União do ônus de serviços antieconômicos e a liberdade tarifária. A privatização do setor ferroviário baseou-se na crença de um potencial de expansão desse modal na matriz de transporte brasileira, somada aos incentivos fiscais de curto prazo oferecidos pelo governo.

Privatizado em 1996, o sistema ferroviário brasileiro é composto por cerca de 29 mil kilômetros de ferrovias, desempenhando papel significativo para o superávit da balança comercial com o transporte de produtos minerais, industriais e agropecuários destinados à exportação (SEMINÁRIO, 2004).

O volume de investimentos realizado pelas concessionárias de ferrovias no setor cresceram 215\% entre 2003 e 2005, chegando a marca de $\mathrm{R} \$ 3,37$ bilhões no ano de 2005 (DNITa, 2008). Apesar dos investimentos, a recuperação da malha ferroviária atual encontra-se entre os principais desafios, destacando-se a precariedade e obsolescência de sua infraestrutura e material rodante.

Segundo o procurador da República Luiz Cláudio Pereira Leivas - que investiga o paradeiro dos bens físicos da extinta RFFSA, incluindo pátios, prédios, depósitos, oficinas, além de trechos inteiros, dispersos pelo território nacional - a opção por transportes de cargas aposentou o transporte de passageiros, sucateando cerca de $4 \mathrm{mil} \mathrm{km}$, dos quais 1.300 apenas no estado de São Paulo. Em dezessete estados, 434 leitos ferroviários foram tomados por ocupações irregulares, como favelas, hotéis, clubes, marinas e loteamentos de luxo, como o verificado na EF-479, interligando Mangaratiba a Angra dos Reis, no litoral fluminense (CORRÊA, 2007). 
Ocupações irregulares ocorrem também ao longo do eixo de linhas férreas ativas, caracterizadas por crescentes invasões das faixas de domínio. Embora não haja legislação específica sobre o assunto - há minuta, mas ainda sem aprovação - adota-se, como regra geral, faixa de domínio como sendo a área livre não edificante de $15 \mathrm{~m}$, a partir do eixo central. Esta distância foi determinada pela Lei 10.932, de 2004, sobre parcelamento do uso do solo urbano, em seu artigo 4º, inciso III.

Conforme dados de 2005 (PEREIRA, 2005), mais de 200 mil famílias habitavam em moradias construídas dentro das faixas de domínio. A proximidade populacional junto às linhas férreas ocasiona limitações no sistema, desde atraso nas viagens, em virtude da redução de velocidade de $70 \mathrm{~km} / \mathrm{h}$ para $10 \mathrm{~km} / \mathrm{h}$ em média, como também acidentes fatais. Acidentes freqüentes são registrados e noticiados (REDE GLOBO, 2007; REDE GLOBO 2008) nas linha $F$ e $A$ da Companhia Paulista de Trens Metropolitanos - CPTM, na capital paulista, provocados por moradores da região que cruzam a linha de forma indevida.

A manutenção constante da infra-estrutura férrea, incluindo o uso correto das faixas de servidão, é imprescindível para que essa modalidade de transporte possa ter suas vantagens exploradas na sua totalidade.

Conforme Ferreira e Murray (1997), a manutenção da infra-estrutura ferroviária tem sido tradicionalmente abordada pelos engenheiros considerando-se apenas os aspectos técnicos envolvidos. Entretanto, alertam para a necessidade da substituição deste enfoque por outro que busque a otimização dos recursos técnicos e financeiros, de forma a garantir vantagem ao usuário final.

Angel et. al. (2001) alegam que os métodos tradicionais de obtenção de dados relativos à operação e manutenção da malha ferroviária utilizam técnicas cuja relação custo e benefício é pouco atrativa. Como alternativa, sugerem o emprego de sensores remotos aerotransportados e orbitais para aquisição de dados com resoluções espacial e temporal de qualidade.

Diante deste cenário, o presente trabalho assume como hipótese que dados provenientes de imagens de satélite de alta resolução, podem 
fornecer informações sobre a cobertura do solo ao longo de eixos de ferrovias, auxiliando o planejamento e gerenciamento de sua infra-estrutura.

\subsection{Objetivo}

O principal objetivo deste trabalho é o mapeamento da cobertura do solo ao longo da faixa de domínio de trem metropolitano e suas adjacências, usando imagem de satélite de alta resolução e técnica de classificação baseada em objetos. Pretende ainda os seguintes objetivos específicos:

- Identificação de atributos inerentes às classes de objetos para distinção de classes de comportamento espectral semelhantes

- Comparação entre os resultados obtidos da classificação automática e a classificação baseada em objetos.

- Validação do uso de imagens de alta resolução espacial para monitoramento da infra-estrutura ferroviária.

\subsection{Justificativa}

Os governos federal e estadual vêm empregando esforços na revitalização do transporte ferroviário de passageiros, objetivando a melhoria da qualidade das grandes metrópoles brasileiras.

Visando garantir maior operacionalidade e segurança ao sistema, a delimitação e uso da faixa de domínio têm sido alvo de estudos e discussões de técnicos e especialistas do setor, motivados tanto pelo elevado número de invasões nestas áreas, como pela ausência de regulamentação específica.

A gestão da faixa de domínio é significativamente onerosa devido à considerável extensão da malha ferroviária brasileira - 29 mil kilômetros aliada à diversidade geográfica. Neste aspecto, o sensoriamento remoto apresenta-se como uma ferramenta eficiente no monitoramento de 
corredores de transporte, e suas respectivas áreas circunvizinhas, gerando dados de alta resolução, passíveis de atualização em curto espaço de tempo a custos reduzidos.

A alta resolução espacial oferecida atualmente pelos satélites comerciais suporta aplicações em gerenciamento de avaliação de riscos e geração de mapas com ênfase nas áreas urbanas, não apenas com caráter ilustrativo, mas principalmente para extração de dados, possibilitada pelo uso de novas técnicas de classificação de imagem.

Técnicas de classificação de imagem baseadas em segmentos ou objetos, não mais em pixels, apresentam melhores resultados por conseguirem agregar dados e funcionalidades de um Sistema de Informação Geográfica - SIG à classificação, tais como relações topológicas entre os elementos identificados na imagem.

\subsection{Descrição dos Capítulos}

Os capítulos 2 e 3 deste trabalho dedicam-se à revisão bibliográfica dos temas sensoriamento remoto e processamento digital de imagens, respectivamente.

O capítulo 4 refere-se aos materiais utilizados na pesquisa, incluindo a caracterização da área de estudo, um descritivo dos dados usados e suas fontes, programas e aplicativos.

No capítulo 5 descreve-se a metodologia pormenorizada e seu desenvolvimento.

Os resultados obtidos são apresentados e comentados no capítulo 6.

O capítulo 7 contém as conclusões e sugestões para futuros trabalhos. 


\section{SENSORIAMENTO REMOTO}

Lillesand et al., (2004) descrevem sensoriamento remoto como a ciência e a arte de se obter informações sobre um objeto, área ou fenômeno através da análise de dados obtidos por instrumentos que não se encontram em contato direto com o alvo objeto de observação. Assim sendo, a aquisição remota de dados pode se dar de diferentes formas, como variações na força gravitacional, distribuição de ondas acústicas e distribuição da energia eletromagnética.

Esta definição, contudo, possui caráter abrangente, considerando a variedade de instrumentos e tipo de energia utilizados. Desta forma, este trabalho adota a definição de Novo (1992), segundo a qual Sensoriamento Remoto compreende a utilização conjunta de modernos sensores, equipamentos para processamentos e transmissão de dados, aeronaves e espaçonaves, para estudo do ambiente terrestre através do registro e análise das interações entre a radiação eletromagnética e as substâncias que compõe o planeta em suas diversas manifestações.

O uso da energia eletromagnética pelo sensoriamento remoto compreende a aquisição de dados - e sua posterior análise - oriundos de processos como propagação da energia na atmosfera, interação entre a energia e materiais localizados sobre a superfície terrestre e a energia refletida por tais materiais, sendo esta última registrada pelo sensor.

O espectro eletromagnético, por sua vez, pode ser dividido em faixas ou bandas espectrais, consistindo no conjunto de freqüências, ou comprimentos de onda, nas quais um determinado sensor opera, conforme pode ser visto na Figura 1. 


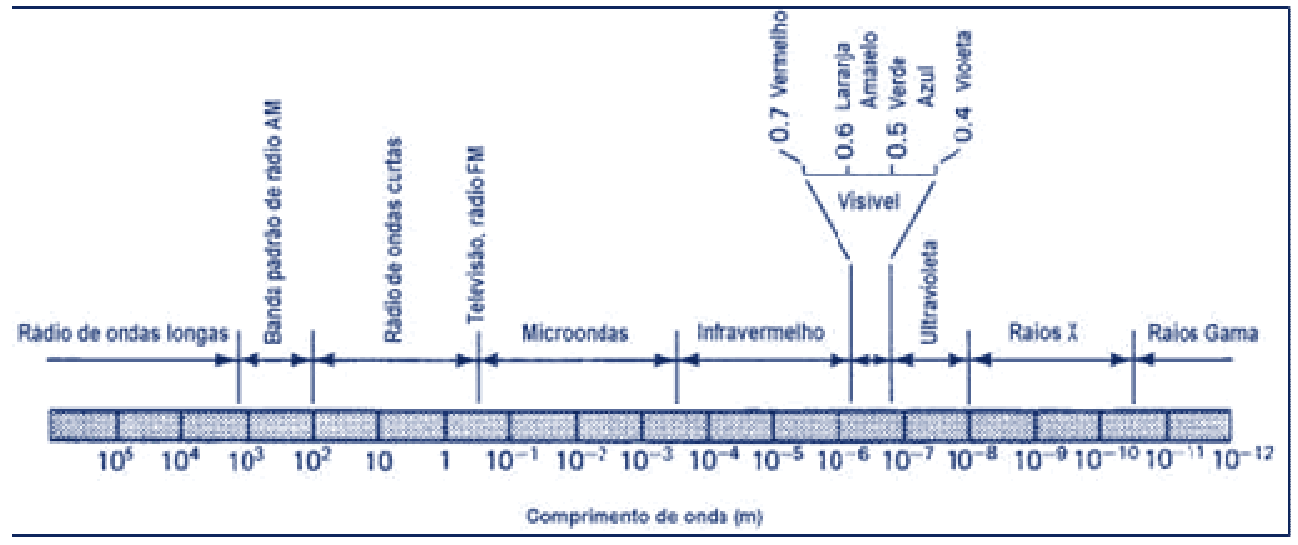

Figura 1. Faixas do espectro eletromagnético.

Fonte: Instituto de Astronomia, Geofísica e Ciências Atmosféricas da

Universidade de São Paulo, disponível em

http://www.astro.iag.usp.br/ mario/aga291/aulas/luz.html.

A região do espectro eletromagnético que desperta maior interesse por parte do sensoriamento remoto é a que se estende da faixa do visível até a da do infra-vermelho (IR). Na região do visível, cores são atributos de determinadas faixas de comprimento de onda, como azul $-0.4 \mu \mathrm{m}$ a $0.5 \mu \mathrm{m}$-, verde $-0.5 \mu \mathrm{m}$ a $0.6 \mu \mathrm{m}$ e vermelha - entre $0.6 \mu \mathrm{m}$ e $0.7 \mu \mathrm{m}$, aproximadamente. Já a região do infra-vermelho divide-se em infra-vermelho próximo - de $0.7 \mu \mathrm{m}$ a $1.3 \mu \mathrm{m}$-, infravermelho médio - $1.3 \mu \mathrm{m}$ a $3 \mu \mathrm{m}$ - e infravermelho termal $-3 \mu \mathrm{m}$ a $14 \mu \mathrm{m}$. Esta última fração é também a única diretamente relacionada a sensação de calor (LILLESAND et al., 2004).

\subsection{Comportamento espectral}

O sensoriamento remoto não pode intervir na emissão de energia dos materiais analisados, tão pouco no meio em que a energia é transportada, mas pode aprender a extrair o máximo de informação contida num sinal (LANDGREBE, 2007). 
A radiometria espectral é uma das áreas fundamentais de estudo no sensoriamento remoto, pois é a intensidade de radiação eletromagnética refletida de cada material, nos diferentes comprimentos de onda do espectro, que explica a forma como cada objeto encontra-se nas imagens (MADEIRA NETTO e MENESES, 2001).

A intensidade da radiação é captada pelos sensores, que são equipamentos capazes tanto da captação da intensidade de radiação refletida pelos materiais, como também pela sua conversão em sinal passível de registro e interpretação. Os sensores são desenvolvidos para operar em uma ou mais bandas, sendo estas definidas de acordo com as características dos alvos que se desejam imagear. Cada banda espectral é responsável pela geração da imagem numa determinada faixa do espectro eletromagnético (TSO e MATHER, 2001).

Quadro 1 - Principais regiões ou intervalos espectrais usados em sensoriamento remoto.

\begin{tabular}{|c|c|c|c|}
\hline Região & $\begin{array}{l}\text { Intervalo espectral } \\
\text { (micrômetro - } \mu \mathrm{m} \text { ) }\end{array}$ & Fonte de radiação & Propriedade medida \\
\hline Visível & $0,4-0,7$ & Sol & Reflectância \\
\hline $\begin{array}{l}\text { Infravermelho } \\
\text { próximo }\end{array}$ & $0,7-1,1$ & Sol & Reflectância \\
\hline $\begin{array}{l}\text { Infravermelho de } \\
\text { ondas curtas }\end{array}$ & $\begin{array}{l}1,1-1,35 \\
1,4-1,8 \\
2,0-2,5\end{array}$ & Sol & Reflectância \\
\hline $\begin{array}{l}\text { Infravermelho } \\
\text { médio }\end{array}$ & $\begin{array}{l}3,0-4,0 \\
4,5-5,0\end{array}$ & $\begin{array}{c}\text { Sol } \\
\text { Corpos terretres com } \\
\text { altas temperaturas }\end{array}$ & $\begin{array}{l}\text { Reflectância } \\
\text { Temperatura }\end{array}$ \\
\hline $\begin{array}{l}\text { Infravermelho } \\
\text { termal }\end{array}$ & $\begin{array}{c}8,0-9,5 \\
10-14\end{array}$ & Terra & Temperatura \\
\hline Microondas, radar & $1 \mathrm{~mm}-1 \mathrm{~m}$ & $\begin{array}{l}\text { Terra (passivo) } \\
\text { Artificial (ativo) }\end{array}$ & $\begin{array}{c}\text { Temperatura (passivo) } \\
\text { Rugosidade de alvos (ativo) }\end{array}$ \\
\hline
\end{tabular}

Fonte: Madeira e Meneses, 2001. 
A Figura 2 representa a curva de reflectância espectral característica de certos elementos naturais e artificiais mais encontrados na superfície terrestre.

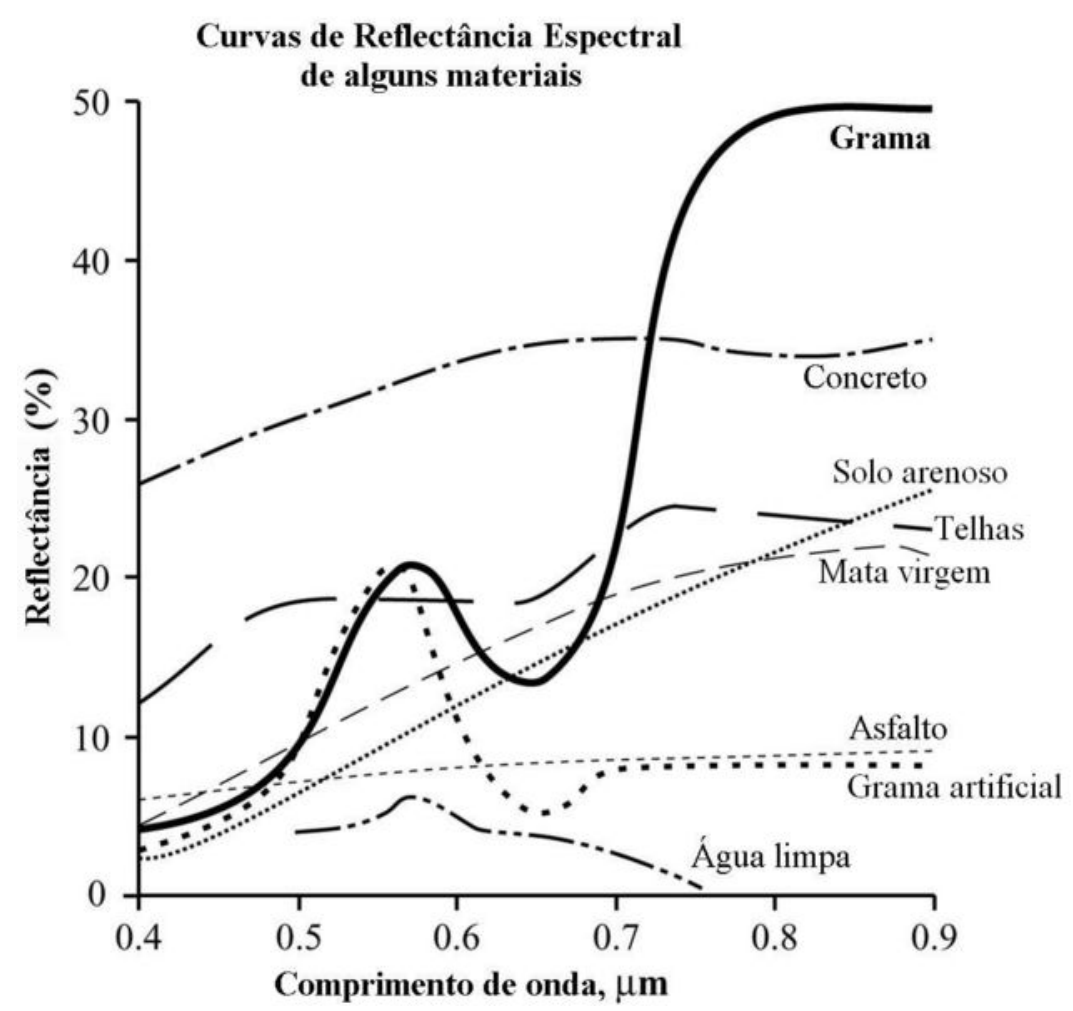

Figura 2 - Curvas de reflectância espectral de alguns materiais.

Fonte: Adaptado de Jensen, 2000

Através do sensoriamento remoto pode-se medir a resposta espectral de diversos materiais e feições, possibilitando a análise dos tipos e condições de tais materiais, o que se convencionou chamar de "assinatura espectral”. Todavia, alguns autores (LILLESAND, 2004), preferem utilizar o termo "padrão de resposta", uma vez que o termo assinatura espectral pode levar a falsa interpretação de que determinados elementos tenham uma resposta espectral única e absoluta.

\subsubsection{Comportamento espectral de superfícies construídas ou urbanizadas}


O espaço urbano das metrópoles é marcado pela grande heterogeneidade do material que o compõem, como asfalto, concreto, solo exposto, vegetação, corpos d'água, telhados de zinco, amianto e cerâmica. Além da diferença entre os componentes químicos de tais elementos, ressalta-se ainda a grande variedade textural e geométrica dos mesmos.

A Figura 3 representa o comportamento espectral de alguns materiais freqüentemente encontrados no ambiente urbano. Dela conclui-se que tais materiais apresentam um padrão de resposta semelhante, principalmente 0 asfalto e o concreto, crescendo juntamente com o comprimento de onda, apresentando maior pico na região do vermelho.

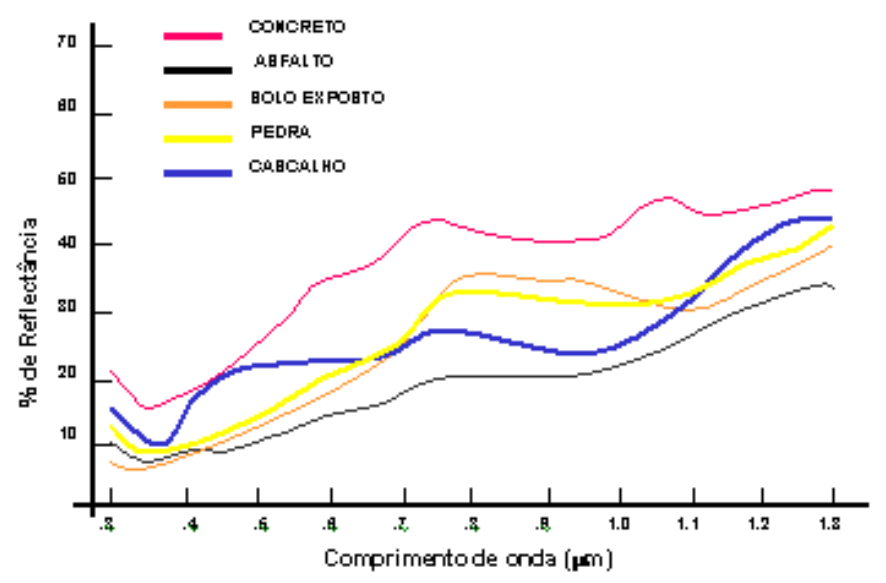

Figura 3 - Comportamento espectral de áreas não vegetadas.

Fonte: Adaptado Logsdon (2003), apud Ohata (2004).

De forma complementar, estudo realizado por Sousa e Kux (2005), ilustrado pela Figura 4, representa o comportamento espectral de outros materiais também encontrados em áreas urbanizadas, relacionado às bandas do satélite CBERS-II. O amianto e o asfalto apresentam um padrão de resposta distinto dos demais materiais, crescendo continuamente ao longo do espectro, aumentando sua reflectância em função do comprimento de onda. 
A telha de barro, não presente na Figura 3, apresenta considerável absorção nas faixas azul e verde do visível, mas sua reflectância eleva-se bruscamente a partir da região do vermelho e atinge seu ápice no infravermelho próximo. Tal comportamento pode ser justificado pela sua coloração avermelhada e seus componentes estruturais.

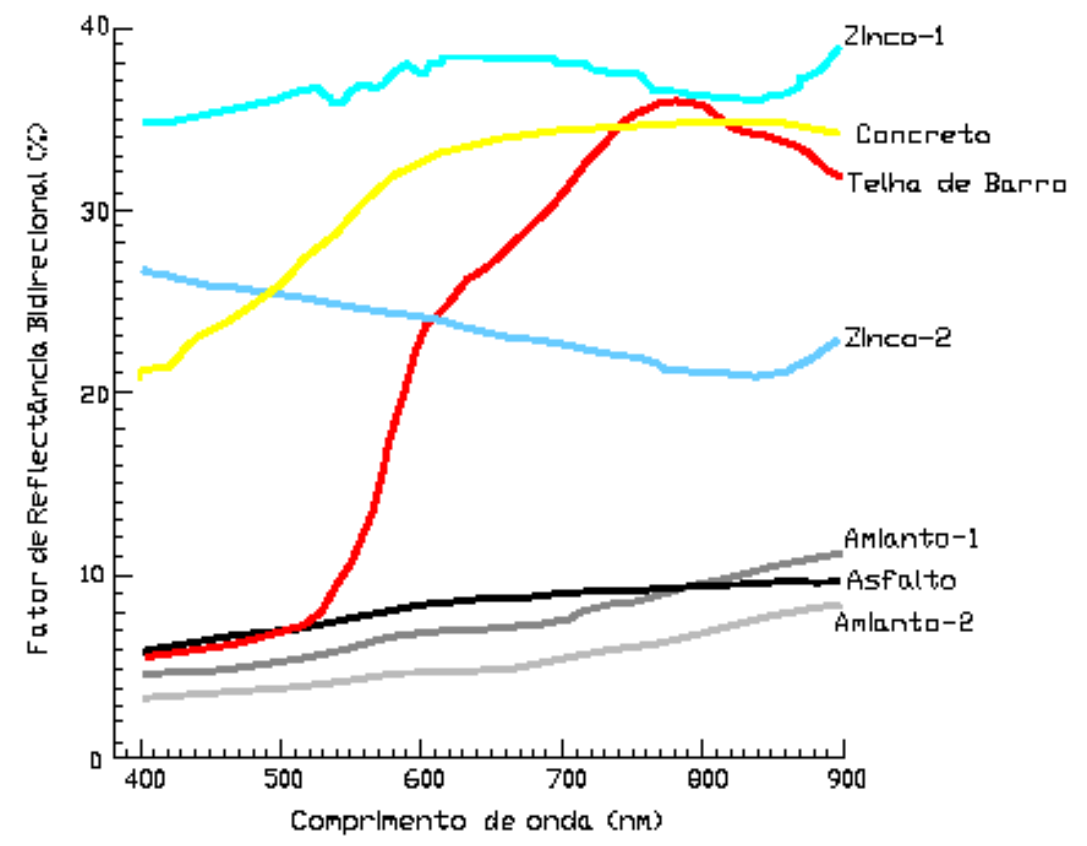

Figura 4 - Comportamento espectral de alvos urbanos.

Fonte: Sousa e Kux (2005).

Além da diversidade de material utilizado nas construções, o ambiente urbano também pode apresentar heterogeneidade em seus elementos naturais, como vegetação, solo e água. A água, quando inserida em contexto urbano, requer maior acuidade em sua análise em função da variedade de substâncias que encontram-se depositadas nos corpos d’água.

\subsubsection{Comportamento espectral da vegetação}

Conforme Ponzoni (2001), os estudos de vegetação através do uso de sensoriamento remoto envolvem, na maioria das vezes, a reflectância 
como o fenômeno mais analisado. Neste contexto, o termo Comportamento Espectral da Vegetação refere-se, freqüentemente, às características de reflectância, transmitância e absortância da energia eletromagnética pelas folhas, plantas individuais e conjunto de plantas. Estes três componentes encontram-se intimamente relacionados, pois somente uma parte da energia incidente na folha é refletida, sendo o restante absorvido e transmitido (KNIPLING, 1970; JENSEN, 2000).

Conforme Knipling (1970), na parte visível do espectro $(0,4 \mu \mathrm{m}$ a 0,7 $\mu \mathrm{m})$, a reflectância da folha é significativamente baixa, cerca de $10 \%$, atingindo seu pico em $0,55 \mu \mathrm{m}$ na região do verde. Este pico é razão pela qual o olho humano enxerga o verde como a cor da vegetação. A reflectância tem seu maior crescimento, cerca de 50\%, na região do infravermelho, entre $0,7 \mu \mathrm{m}$ e 1,3 $\mu \mathrm{m}$, a partir da daí apresenta um decréscimo gradual, chegando ao seu menor valor em 2,7 $\mu \mathrm{m}$. Este pico na região do infravermelho deve-se à presença de água, enquanto na região do visível à presença de pigmentos, principalmente da clorofila. $O$ autor esclarece ainda que a alta reflectância verificada na região do infravermelho é decorrente da estrutura celular interna da folha. Nesta mesma faixa, cerca de $40 \%$ a $60 \%$ da energia é espalhada para cima através da superfície incidente, sendo considerada como refletida. O restante da energia é espalhado para baixo, constituindo a energia transmitida. Este mecanismo interno de espalhamento de energia explica a forma similar da energia refletida e transmitida ao longo do espectro.

Conforme Ponzoni (2001), os dosséis apresentam-se em tonalidades escuras na região do visível em virtude da ação de pigmentos fotossintetizantes, que por sua vez provocam baixa reflectância. Já na região do infravermelho próximo, estes mesmos dosséis surgirão em tonalidades mais claras.

Estes autores consideram um dossel como um conjunto de subdosséis, arranjados no solo de forma regular ou não. Para um dossel, considera-se que a densidade dos elementos da vegetação é homogêneo, definido pelo índice de massa foliar (IAF): razão entre a área do elemento e 
a área do terreno em que o mesmo se encontra. Este é um dos principais parâmetros da vegetação, sendo bastante aplicado em modelos de crescimento vegetal, evapotranspiração e biomassa.

Ao longo das últimas décadas, pesquisadores vêm se utilizando de medidas espectrais como forma de obter informações sobre os aspectos quantitativos e qualitativos da vegetação, relacionados, principalmente, à identificação de áreas vegetadas e suas características biofísicas.

Para tanto, diversos índices de vegetação foram desenvolvidos, consistindo em operações matemáticas envolvendo duas ou mais bandas espectrais, vermelho (visível) e infravermelho próximo em sua maioria, cujo resultado corresponde à quantidade e qualidade da vegetação presente na imagem (REES, 1999 e MATHER, 2005). Os índices originados destas duas bandas partem de uma propriedade física simples: plantas refletem menos luz vermelha, mas muito mais radiação infravermelha se comparadas a elementos não vegetativos. O Quadro 3 apresenta os índices de vegetação mais utilizados.

Quadro 2 - Fórmula dos índices de vegetação do vermelho e infravermelho próximo.

\begin{tabular}{|c|c|c|c|}
\hline Sigla & Denominação & Fórmula & Proponente \\
\hline RVI & $\begin{array}{l}\text { Índice de Razão de } \\
\text { Vegetação }\end{array}$ & $\mathrm{RVI}=\mathrm{IVP} / \mathrm{V}$ & Jordan (1969) \\
\hline NDVI & $\begin{array}{l}\text { Índice de Vegetação de } \\
\text { Diferença Normalizada }\end{array}$ & $\mathrm{NDVI}=(\mathrm{IVP}-\mathrm{V}) /(\mathrm{IVP}+\mathrm{V})$ & $\begin{array}{l}\text { Rouse et al. } \\
(1973)\end{array}$ \\
\hline SAVI & $\begin{array}{l}\text { Índice de Vegetação } \\
\text { Ajustado ao Solo }\end{array}$ & $\mathrm{SAVI}=((\mathrm{IVP}-\mathrm{V}) /(\mathrm{IVP}+\mathrm{V}))(1+\mathrm{L})$ & Houte (1988) \\
\hline ARVI & $\begin{array}{l}\text { Índice de Vegetação com } \\
\text { Resistência Atmosférica }\end{array}$ & $\begin{array}{l}A R V I=(I V P-(2 \mathrm{~V}-\mathrm{A})) / \\
(I V P+(2 \mathrm{~V}-\mathrm{A}))\end{array}$ & $\begin{array}{ll}\text { Kaufman } & \mathrm{e} \\
\text { Tanre (1996) } & \end{array}$ \\
\hline EVI & $\begin{array}{l}\text { Índice de Realce da } \\
\text { Vegetação }\end{array}$ & $\begin{array}{l}E V I=G((I V P-V) / \\
\left.\left(I V P+C_{1}{ }^{*} V-C_{2}{ }^{*} A+L\right)\right)\end{array}$ & $\begin{array}{l}\text { Houte et al.; } \\
(2002)\end{array}$ \\
\hline
\end{tabular}

Fonte: Adaptado de Soudani et al., 2006.

O NDVI ainda é o mais amplamente utilizado para identificação das características biofísicas da vegetação (LEEUWEN e ORR, 2006; 
POCEWICZ et al., 2007), muito embora suas variações - SAVI e ARVI tenham apresentado melhores resultados para casos específicos (CARREIRAS et al., 2006, GONZÁLEZ-DUGO e MATEOS, 2006; BELTRAME et al., 2007; SANTER et al., 2007). Apesar de terem sido desenvolvidos para aplicação em bandas de sensores de menor resolução espacial, os mesmos têm apresentado bons resultados quando aplicados em imagens geradas por sensores de maior resolução espacial, como IKONOS II e QuickBird (SOUDANI et al., 2006; BELTRAME et al., 2007).

\subsubsection{Comportamento espectral do solo}

A curva de reflectância do solo apresenta uma homogeneidade maior, comparativamente à da vegetação, apresentando pouca variação entre os comprimentos de onda. Conforme Curran (1985), cinco características do solo interferem de forma determinante na resposta espectral do mesmo, estando todas inter-relacionadas: a) umidade, b) matéria orgânica, c) textura, d) estrutura e, e) presença de óxido de ferro.

Quanto maior a umidade encontrada no solo, menor será a reflectância deste, uma vez que a presença de água provoca maior absorção da energia incidente. Contudo, solos de uma mesma classe podem ainda apresentar reflectâncias diferentes devido à concentração e tamanho das partículas que os compõem. A textura e a estrutura, exemplificando o interrelacionamento mencionado acima, são responsáveis pela quantidade e tamanho dos espaços porosos, que são ocupados pela a água e o ar (MOREIRA, 2005).

A matéria orgânica, por sua vez, é inversamente proporcional à reflectância do solo no intervalo de comprimento de onda. Quanto maior a ocorrência de material orgânico, maior é a absorção de energia incidente e, conseqüentemente, menor é a sua reflectância.

O óxido de ferro é o que confere ao solo sua coloração vermelho ferrugem e, em geral, apresentam maior absorção na região do infravermelho e maior reflectância na faixa do vermelho. 


\subsubsection{Comportamento espectral da água}

A resposta espectral da água é bastante distinta em relação aos seus estados, enquanto no estado gasoso e sólido a reflectância pode atingir cerca de $70 \%$, no estado líquido esse mesmo índice encontra-se abaixo de 5\% (MOREIRA, 2005). Segundo Curran (1985), ao contrário do que ocorre com a vegetação e o solo, a energia incidente sobre a água quase não é refletida, sendo sim, absorvida ou transmitida. A água em estado líquido absorve na região do infra-vermelho próximo e, principalmente, no médio, resultando no contraste entre um corpo d água e as margens de terra.

Ainda segundo o autor, à semelhança do que ocorre com o solo, a reflectância da água sofre influências ambientais decisivas, como a profundidade do corpo d’água, o grau de rugosidade deste corpo e possíveis materiais em suspensão, como clorofila, minerais e materiais orgânicos em decomposição.

\subsection{Sistemas sensores}

A estrutura básica de um satélite é composta por duas partes distintas: a) o sistema sensor, que compreende o sistema de aquisição de dados e, b) sistema satélite, que controla diversos sub-sistemas, como o de controle de altitude, controle térmico, energia e comunicação. O sistema sensor consiste nos equipamentos - como câmeras e lentes - utilizados para aquisição de dados, podendo haver mais de um tipo de sensor a bordo.

Um sistema sensor é composto por quatro elementos: a) o coletor, responsável pela recepção da energia, geralmente através de lentes, espelhos e antenas; b) o detetor, responsável pela captação da energia dentro de uma determinada faixa do espectro; c) o processador, que processa o sinal captado e o transforma em produto e; d) o produto, que é a informação final disponível ao usuário (INPE, 2008). 
Os sensores podem ser classificados de acordo com a fonte de energia utilizada e com o produto gerado. No primeiro caso, os sensores podem ser ativos, quando possuem fonte própria de radiação de energia, ou passivos, quando não possuem fonte própria, mas medem a radiação solar refletida ou emitida pelos alvos. Quanto ao produto gerado, eles podem ser não-imageadores, quando seu produto não é uma imagem da superfície sensoriada, ou imageadores, quando o resultado obtido do sensoriamento é uma imagem, da qual pode-se extrair informações sobre a variação espacial da resposta espectral da superfície observada (INPE, 2008).

Os sistemas sensores imageadores podem ainda ser classificados de acordo com seu princípio de funcionamento. Os sensores são considerados de varredura (scanning systems) quando a imagem formada é resultado de uma coleta seqüencial de pixels, ou podem ainda ser sensores de nãovarredura (non scanning systems) quando registram a radiação refletida de uma determinada superfície num determinado momento.

Os sistemas sensores imageadores podem ser caracterizados de acordo sua resolução em quatro parâmetros distintos:

- Resolução espacial: refere-se à capacidade do sensor em identificar objetos na superfície da terrestre, correspondendo ao tamanho de área coberta por um único pixel. Quanto menor for a área contida num pixel, ou ainda, quanto menor for um objeto visualmente identificável na cena, maior será a resolução espacial.

- Resolução espectral: corresponde ao número de bandas espectrais do sistema sensor e a largura do intervalo de comprimento de onda coberto por cada banda, quanto maior o número de bandas, maior a resolução espectral. Em termos práticos, quanto maior o número de bandas espectrais disponíveis, maior será a possibilidade de obter uma rigorosa discriminação entre os diversos materiais encontrados numa cena, com base nas suas respostas espectrais.

- Resolução radiométrica: corresponde ao número de níveis digitais, ou níveis de cinza, usados para expressar dados coletados pelo sensor, quanto maior o número de níveis, maior é a resolução radiométrica 
(CRÓSTA, 1999). Juntamente com o número de bandas, o número de valores discretos possíveis de serem encontrados numa banda estão diretamente relacionados com o nível de detalhe que se pode atingir para separar as diferentes classes de materiais numa cena (LANDGREBE, 2007).

- Resolução temporal: corresponde ao intervalo de vezes que o sensor observa uma mesma área do terreno em um determinado período. Quanto menor for este intervalo, maior será a resolução temporal.

Esses parâmetros estão intrinsicamente relacionados, considerandose que a capacidade de um material emitir intensidade de radiação dentro de um campo eletromagnético é limitada. Desta forma, é preciso buscar a melhor combinação entre tamanho de pixel, largura de cada banda e a precisão da medição radiométrica para cada pixel e banda (Landgrebe, 2007).

Ao longo dos anos, o avanço da tecnologia tem permitido o desenvolvimento de satélites com resoluções cada vez maiores, principalmente a espacial. A série de satélites LANDSAT, primeira a ser lançada pela NASA, na década de 70, largamente utilizada para análises ambientais, possui resolução espacial de $30 \mathrm{~m} \times 30 \mathrm{~m}$. A série SPOT, desenvolvida por iniciativa do governo francês em 1978, com a participação da Suécia e Bélgica, é gerenciada pelo Centro Nacional de Estudos Espaciais - CNES, que é o responsável pelo desenvolvimento do programa e operação dos satélites. A resolução espacial desta série, inicialmente na faixa de $10 \mathrm{~m}$ a $20 \mathrm{~m}$ com o lançamento do SPOT1, em 1986. Atualmente, encontram-se em órbita SPOT4 e 5, sendo que a resolução espacial deste último varia de $10 \mathrm{~m}$ a $5 \mathrm{~m}$, dependendo do sensor, podendo chegar a $2,5 \mathrm{~m}$ na pancromática. Ambas as séries são classificadas como sensores de resolução intermediária.

Todavia, a demanda crescente por imagens de maior resolução, muito próximas da apresentadas por fotografias aéreas (cerca de $1 \mathrm{~m} \times 1 \mathrm{~m}$ ), fez com que novos sensores fossem desenvolvidos e, no final da década de 90 , surgiu o primeiro satélite comercial com imagens de alta resolução espacial, 
- IKONOS I. Atualmente, entre os satélites comerciais de alta resolução, destacam-se o IKONOS II e o QuickBird, cuja resolução espacial chega a $1 \mathrm{~m}$ e $0,6 \mathrm{~m}$, respectivamente.

\subsection{IKONOS II}

Este satélite foi lançado no dia 24 de setembro de 1999, entrando em operação desde o início de janeiro de 2000 (ARONOFF, 2005). As imagens de alta resolução, até então utilizadas apenas para fins militares, tornaramse comercialmente disponíveis para qualquer área do globo. Esta tecnologia para aplicações civis é conseqüência direta da liberação tecnológica iniciada em 1994 pelo governo americano.

A alta resolução do IKONOS II provocou uma mudança no uso das imagens de satélite, pois se anteriormente um pixel continha vários objetos, a partir daí, um objeto passou a ser composto de vários pixels. As principais características do sensor IKONOS II são apresentadas no Quadro 2.

Quadro 3 - Principais características do sensor IKONOS II.

\begin{tabular}{|c|c|}
\hline Característica & IKONOS II \\
\hline Altitude & $680 \mathrm{~km}$ \\
\hline Inclinação & $98,1^{\circ}$ \\
\hline Velocidade & $9 \mathrm{~km} /$ segundo \\
\hline Duração da órbita & Sol-síncrona \\
\hline Tipo de órbita & Pancromática: $1 \mathrm{~m} /$ \\
\hline Resolução espacial & Multiespectral: $4 \mathrm{~m}$ \\
\hline Resolução espectral & Pan $0.45-0.90 \mu \mathrm{m}$ \\
& Azul $0.45-0.52 \mu \mathrm{m}$ \\
& Verde $0.52-0.60 \mu \mathrm{m}$ \\
& Vermelho $0.63-0.69 \mu \mathrm{m}$ \\
& Infra vermelho próximo $0.76-$ \\
& $0.90 \mu \mathrm{m}$ \\
\hline Imageamento & $13 \mathrm{~km} \times 13 \mathrm{~km}$ \\
& \\
\hline
\end{tabular}




\begin{tabular}{|c|c|}
\hline Característica & IKONOS II \\
\hline Freqüência de revisita & 2.9 dias a $1 \mathrm{~m}$ de resolução \\
& Esses valores valem para \\
& latitude $d e+/-40^{\circ}$. \\
\hline
\end{tabular}

Fonte: Adaptado de GeoEye (http://www.geoeye.com/).

As imagens geradas em todas as suas bandas possuem 11 bits de resolução radiométrica, equivalendo a 2048 níveis de cinza. Seus sensores capturam imagens com $4 \mathrm{~m}$ de resolução espacial nas bandas do visível (azul, verde e vermelho) e infravermelho próximo, e $1 \mathrm{~m}$ na pancromática. Combinando-se as bandas multiespectrais com a pancromática pode-se obter imagem com $1 \mathrm{~m}$ de resolução espacial (ARONOFF, 2005).

\subsection{Identificação do uso e cobertura do solo}

As mudanças verificadas no uso e cobertura do solo de áreas urbanas, ocorrem com tamanha rapidez e abrangência que seu controle passa a ser quase que inexeqüível. As conseqüências desse crescimento ocorrido nos grandes centros urbanos, tornaram-se alvo de preocupações de seus gestores, visando salvaguardar a qualidade de vida de sua população.

Autores como Novo (1989) e Jensen (2000) atentam para distinção entre os termos "uso" e "cobertura" da terra. Segundo os autores, o uso compreende o modo como a terra é utilizada, enquanto cobertura refere-se aos materiais biofísicos encontrados na superfície.

O uso do sensoriamento remoto, aliado a dados sócio-econômicos georreferenciados, constitui poderosa ferramenta na identificação das mudanças ocorridas na paisagem urbana, além de subsidiar estratégias no sentido de minimizar os efeitos do desenvolvimento urbano no meio ambiente (ALBERTI et al., 2003). Diversas pesquisas realizadas ao longo da última década (HEROLD et al., 2001; XIUWAN, 2002; ABBATE et al., 2003; SCHENEIDER et al., 2005; ZHU e TATEISHI, 2006; KUX et al., 2007) demonstram haver consenso de que as imagens de alta resolução são uma 
alternativa viável para análise de mudanças ocorridas no uso e cobertura do solo, além de apontar tendências de expansão da mancha urbana.

Embora a grande maioria dos trabalhos desenvolvidos relacionados à classificação do uso e cobertura do solo tenha sido realizada com base no conhecimento prévio da área por parte do analista, a literatura dispõe de sistemas de classificação desenvolvidos para esta finalidade.

Um dos sistemas classificatórios comumente utilizados (BRANDÃO E PARADELLA, 2003; TEOTIA et al., 2003; OHATA, 2004; GAMBA e LUCHIARI, 2005; MONTEBELO et al., 2005) desenvolvido por Anderson et al. (1979), caracteriza-se por níveis hierárquicos. Os níveis hierárquicos são definidos seguindo critérios como o tipo do sensor utilizado - considerandose altura e resolução espacial - e a escala do mapeamento a ser realizado. Todavia, Anderson et al. (1979) estabeleceram classes apenas para os dois primeiros níveis, deixando os demais livres para serem devidamente adaptados de acordo com as características da região estudada, bem como dos recursos do sensor utilizado.

Este sistema foi adotado pela United State Geological Survey USGS, tendo sido utilizado inicialmente para comparar o mapeamento da cobertura do solo com o mapeamento do uso do solo, cuja classificação adotava outros sistemas. Na seqüência, a instituição adaptou o sistema detalhando classes para os níveis III e IV (JENSEN, 2000). A título de exemplificação do sistema, o Quadro 3 apresenta os níveis três primeiros níveis de classificação para a classe "terra urbana ou edificada", por ser a categoria de maior interesse para o projeto. O nível IV não foi apresentado em virtude de seu alto nível de detalhamento, além de retratar a realidade do território americano, não se aplicando, necessariamente, a realidade do territoório brasileiro.

Quadro 4 - Adaptação do Sistema USGS de classificação do uso e cobertura do solo, 1992.

\begin{tabular}{|l|c|l|l|}
\hline Classes Nível I & Classes Nível II & \multicolumn{2}{|c|}{ Nível III } \\
\cline { 3 - 4 } & & Classe & Descrição \\
\hline
\end{tabular}




\begin{tabular}{|c|c|c|c|}
\hline \multirow[t]{2}{*}{ Classes Nível I } & \multirow[t]{2}{*}{ Classes Nível II } & \multicolumn{2}{|c|}{ Nível III } \\
\hline & & Classe & Descrição \\
\hline \multirow[t]{14}{*}{$\begin{array}{l}\text { 1. Terra urbana ou } \\
\text { edificada }\end{array}$} & \multirow[t]{2}{*}{ 1.1 Residencial } & $\begin{array}{l}1.1 .1 \text { Residência } \\
\text { unifamiliar }\end{array}$ & $\begin{array}{l}\text { Diferencia-se de outras } \\
\text { estruturas residenciais } \\
\text { por ser atendida por via } \\
\text { simples, calçada, jardim } \\
\text { e quintal. }\end{array}$ \\
\hline & & $\begin{array}{l}1.1 .2 \text { Residência } \\
\text { multifamiliar }\end{array}$ & $\begin{array}{ll}\text { Possui mais de uma } \\
\text { calçada, } & \text { grande } \\
\text { estacionamento, } & \text { jardim } \\
\text { comum à várias } \\
\text { unidades. }\end{array}$ \\
\hline & \multirow[t]{2}{*}{$\begin{array}{l}1.2 \text { Comércio e } \\
\text { serviços }\end{array}$} & 1.2.1 Comercial & $\begin{array}{l}\text { Setor automotivo, } \\
\text { barcos, lojas de } \\
\text { departamento, finanças } \\
\text { e } \quad \text { construção, } \\
\text { alimentação, etc. }\end{array}$ \\
\hline & & $\begin{array}{l}1.2 .2 \quad \text { Serviços } \\
\text { públicos e privados }\end{array}$ & $\begin{array}{l}\text { Administração pública, } \\
\text { educação, corpo de } \\
\text { bombeiros, postos de } \\
\text { saúde, etc. }\end{array}$ \\
\hline & \multirow[t]{3}{*}{1.3 Indústria } & 1.3.1 Extração & Minas, pedreiras. \\
\hline & & 1.3.2 Processamento & $\begin{array}{l}\text { Mecânica, química, } \\
\text { térmica }\end{array}$ \\
\hline & & 1.3.3 Fabricação & Metal, elétrica. \\
\hline & \multirow{3}{*}{$\begin{array}{l}1.4 \quad \text { Transporte, } \\
\text { comunicação } \\
\text { utilidades }\end{array}$} & 1.4.1 Transporte & $\begin{array}{ll}\text { Rodovias, ferrovias, } \\
\text { aeroportos. }\end{array}$ \\
\hline & & 1.4.2 Comunicação & Rádios, tvs \\
\hline & & $\begin{array}{ll}1.4 .3 \text { Rede } & \text { de } \\
\text { utilidades } & \\
\end{array}$ & $\begin{array}{l}\text { Eletricidade, gás, } \\
\text { saneamento, petróleo. }\end{array}$ \\
\hline & \multirow{2}{*}{$\begin{array}{l}1.5 \quad \text { Complexos } \\
\text { industriais } \\
\text { comerciais }\end{array}$} & $\begin{array}{l}1.5 .1 \text { Complexos } \\
\text { industriais }\end{array}$ & Parques industriais \\
\hline & & $\begin{array}{l}1.5 .2 \text { Complexos } \\
\text { comerciais }\end{array}$ & Shopping centers. \\
\hline & \multicolumn{3}{|c|}{ 1.6 Misto de área urbana ou edificada } \\
\hline & \multicolumn{3}{|c|}{1.7 Outras áreas urbanas ou edificadas } \\
\hline \multicolumn{4}{|l|}{ 2. Terra agrícola } \\
\hline \multicolumn{4}{|l|}{ 3. Pastagem } \\
\hline \multicolumn{4}{|l|}{ 4. Terra florestal } \\
\hline \multicolumn{4}{|l|}{ 5. Água } \\
\hline \multicolumn{4}{|l|}{ 6. Terra úmida } \\
\hline \multicolumn{4}{|l|}{ 7. Terra árida } \\
\hline \multicolumn{4}{|l|}{ 8. Tundra } \\
\hline
\end{tabular}

Fonte: Adaptado de Jensen (2000).

Outra proposta de sistema de classificação do uso e cobertura do solo é apresentada pelo CORINE - Coordination of Information of Environment (BOSSARD et al., 2000) programa criado com objetivo de fornecer informações sobre o meio ambiente à União Européia. Da mesma forma que o sistema anterior, a classificação segue uma ordem hierárquica, sendo o 
primeiro nível composto por 5 classes, o segundo por 15 e o terceiro por 44 classes. O Quadro 4 apresenta o nível I, relacionando as sub-classes dos níveis II e III somente para as classes "áreas artificiais" e "corpos d’água, por serem as identificadas na área de estudo.

Quadro 5. Sistema CORINE para classificação da cobertura do solo, 1994.

\begin{tabular}{|c|c|c|c|}
\hline \multirow[b]{2}{*}{ Classes Nível I } & \multirow[b]{2}{*}{ Classes Nível II } & \multicolumn{2}{|c|}{ Nível III } \\
\hline & & Classes & Descrição \\
\hline \multirow[t]{11}{*}{ 1. Áreas artificiais } & \multirow[t]{2}{*}{ 1.1Tecido urbano } & $\begin{array}{l}\text { 1.1.1 Tecido urbano } \\
\text { contínuo }\end{array}$ & $\begin{array}{l}\text { Edifícios, estradas e } \\
\text { superfície artificial } \\
\text { cobrindo mais de } 80 \% \\
\text { da área. Áreas verdes } \\
\text { não lineares e solo } \\
\text { exposto é raro. }\end{array}$ \\
\hline & & $\begin{array}{l}\text { 1.1.2 Tecido urbano } \\
\text { descontínuo }\end{array}$ & $\begin{array}{l}\text { Idem a anterior, todavia } \\
\text { ocupando áreas } \\
\text { descontínuas. }\end{array}$ \\
\hline & \multirow[t]{4}{*}{$\begin{array}{lr}1.2 & \text { Comércio, } \\
\text { indústria } & \mathrm{e} \\
\text { transportes. } & \end{array}$} & $\begin{array}{l}\text { 1.2.1 Unidades } \\
\text { industriais e } \\
\text { comerciais }\end{array}$ & $\begin{array}{l}\text { Superfícies artificiais } \\
\text { como concreto, asfalto, } \\
\text { macadame } \\
\text { laminados. Presença } \\
\text { pouco significativa de } \\
\text { edifícios e vegetação. }\end{array}$ \\
\hline & & $\begin{array}{ll}1.2 .2 & \text { Estradas, } \\
\text { ferrovias e faixas de } \\
\text { servidão. }\end{array}$ & $\begin{array}{l}\text { Rodovias, ferrovias e } \\
\text { instalações } \\
\text { comorsociadas, } \\
\text { plataformas, estações, } \\
\text { Largura mínima } 100 \mathrm{~m} \text {. }\end{array}$ \\
\hline & & $\begin{array}{ll}1.2 .3 & \text { Áreas } \\
\text { portuárias } & \end{array}$ & $\begin{array}{l}\text { Áreas } \quad \text { portuárias } \\
\text { incluindo cais, } \\
\text { estaleiros e marinas. }\end{array}$ \\
\hline & & 1.2.4 Aeroportos & $\begin{array}{l}\text { Aeroportos, incluindo } \\
\text { pista, edifícios } \\
\text { terrenos associados. }\end{array}$ \\
\hline & \multirow[t]{3}{*}{$\begin{array}{l}\text { 1.3 Minas, aterros e } \\
\text { canteiros de obra }\end{array}$} & $\begin{array}{ll}1.3 .1 & \text { Extração } \\
\text { mineral } & \end{array}$ & $\begin{array}{l}\text { Áreas abertas de } \\
\text { extração de material de } \\
\text { construção } \\
\text { areeiro). }\end{array}$ \\
\hline & & 1.3.2 Aterros & Públicos ou industriais \\
\hline & & $\begin{array}{lll}1.3 .3 & \text { Canteiro de } \\
\text { obras } & & \end{array}$ & $\begin{array}{l}\text { Áreas sob construção, } \\
\text { com escavações no } \\
\text { solo ou pedra. }\end{array}$ \\
\hline & \multirow[t]{2}{*}{$\begin{array}{l}1.4 \text { Áreas verdes } \\
\text { artificais }\end{array}$} & $\begin{array}{ll}1.4 .1 & \text { Vegetação } \\
\text { urbana } & \end{array}$ & $\begin{array}{l}\text { Áreas verdes dentro do } \\
\text { tecido urbano, como } \\
\text { parques, cemitérios- } \\
\text { parque e jardins de } \\
\text { mansões. }\end{array}$ \\
\hline & & $\begin{array}{l}1.4 .2 \quad \text { Áreas } \\
\text { esporte e lazer }\end{array}$ & $\begin{array}{lrr}\text { Campos de } & \text { golfe, } \\
\text { acampamento, canchas } \\
\text { e parques } & \text { não } \\
\text { rodeados por área } \\
\text { urbana }\end{array}$ \\
\hline
\end{tabular}




\begin{tabular}{|c|c|c|c|}
\hline \multirow[b]{2}{*}{ Classes Nível I } & \multirow[b]{2}{*}{ Classes Nível II } & \multicolumn{2}{|c|}{ Nível III } \\
\hline & & Classes & Descrição \\
\hline \multicolumn{4}{|l|}{ 2. Áreas agrícolas } \\
\hline \multicolumn{4}{|c|}{ 3. Florestas e áreas naturais } \\
\hline \multicolumn{4}{|c|}{ 4. Terras alagadas } \\
\hline \multirow[t]{5}{*}{ 5. Corpos d`água } & \multirow[t]{2}{*}{ 5.1 Água doce } & 5.1.1 Cursos d’água & $\begin{array}{l}\text { Cursos naturais ou } \\
\text { artificiais, usados como } \\
\text { canais de drenagem. }\end{array}$ \\
\hline & & 5.1.2 Corpos d’água & $\begin{array}{l}\text { Trechos naturais ou } \\
\text { artificiais de água }\end{array}$ \\
\hline & \multirow[t]{3}{*}{ 5.2 Água salgada } & 5.2.1 Lagoa costeira & $\begin{array}{l}\text { Trechos de água } \\
\text { salgada localizados } \\
\text { próximos ao mar, deste } \\
\text { separados por uma } \\
\text { península ou terreno de } \\
\text { topografia similar. }\end{array}$ \\
\hline & & 5.2.2 Estuários & $\begin{array}{l}\text { Foz ou vazante de um } \\
\text { rio, desembocando na } \\
\text { maré. }\end{array}$ \\
\hline & & 5.2.3 Mar e oceano & $\begin{array}{l}\text { Zona em direção ao } \\
\text { mar }\end{array}$ \\
\hline
\end{tabular}

Fonte: Adaptado de Bossard et al. (2000).

Embora tais classes tenham sido criadas com o propósito de categorizar todo o território europeu - tendo sido empregadas com êxito em classificações envolvendo os dois primeiros níveis nesse continente (MUCHER, 2000, TÖRMÄ e HARMÄ, 2004; SIEDENTOP e MEINEL, 2004) - o presente trabalho pretende adotá-las no mapeamento da cobertura do solo por entender que esse sistema é o que melhor se adapta às finalidades do projeto. Comparativamente, os dois primeiros níveis de ambos os sistemas assemelham-se, mas a partir do terceiro nível, o sistema do USGS foca mais no uso das áreas classificadas, como comércio e serviços públicos, enquanto o CORINE procura caracterizar as áreas com base em sua composição e arranjo espacial.

\subsection{Aplicações na área de transporte}

Segundo Goodchild et al (2001), há anos atrás o sensoriamento remoto já oferecia uma grande variedade de dados a serem utilizados para o planejamento e gerenciamento de transporte, mas em formatos que demandavam considerável carga de pré-processamento e alto nível de 
habilidade para seu manuseio, o que, por vezes, o tornava inviável. Todavia, com o surgimento de novos ferramentais tecnológicos, como bibliotecas digitais, mecanismos de pesquisa e Sistema de Informação Geográfica (SIG) - viabilizou a oferta e o desenvolvimento de produtos que, por sua vez, vieram ao encontro às necessidades da área de transportes, como o sensor sub-orbital Light Detecting and Ranging - LIDAR $^{1}$ e o orbital IKONOS II. A relação de demanda e oferta de dados pode ser melhor entendida conforme o fluxo demonstrado na Figura 5.

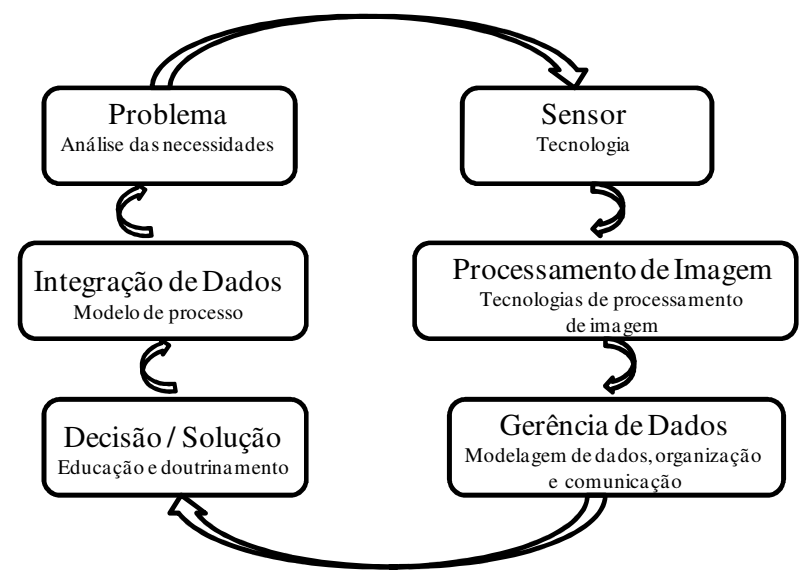

Figura 5. Sensoriamento remoto no contexto de demanda de informação na área de transporte.

Fonte: Adaptado de Goodchild et al. (2001)

Atualmente, o sensoriamento remoto subsidia com dados e informações atividades de planejamento e gerenciamento de transporte, principalmente estudos de análise ambiental e infra-estrutura e logística incluindo transporte de materiais perigosos.

\subsubsection{Análise ambiental}

1 Sensor aerotransportado capaz de adquirir milhares de pontos geo-referenciados por segundo, através da emissão de feixes laser. A distância entre o sensor e o alvo é calculada com base no tempo decorrido entre a emissão do feixe e seu retorno ao sensor após tocar a superfície imageada. A resolução espacial varia em função da velocidade, altura e ângulo de varredura (DALMOLIN e SANTOS, 2005). 
King e O'Hara (2001) destacam oportunidades para exploração das imagens de sensoriamento remoto - com incremento de suas resoluções espaciais, radiométricas e temporais - para analisar o relacionamento entre a expansão urbana e a expansão da rede de transportes e os impactos ambientais por ele provocados. Os impactos ambientais podem ser mensurados e analisados de diferentes formas, sendo as mais comuns a detecção de mudanças no uso e cobertura do solo e a medição, análise e modelagem da qualidade do ar.

Diversos trabalhos foram desenvolvidos abordando a mudança no uso e cobertura do solo após a implantação de corredores de transporte, mas com diferentes abordagens. Muitas pesquisas procuram identificar a evolução das classes de cobertura do solo usando séries temporais de diferentes sensores (MADHAVAN et al., 2001; STEINMEIER e MULLER, 2004; GUINDON et al., 2004; KAYA e CURRAN, 2006; ZHU e TATEISHI, 2006; LAMBIN e LINDERMAN, 2006). Outros partem do uso de imagens de satélite para extração de índices como acessibilidade e proximidade (JHA e KIM, 2006; MACHADO, 2008), sustentabilidade - atividades econômicas e uso de recursos naturais como água e energia (SHORE, 2006; ALMEIDA, 2006).

King e O'Hara (2001) ressaltam o sucesso do emprego de sensoriamento remoto para analisar o impacto do transporte na qualidade do ar, relacionando níveis de contaminação do ar com volume de tráfego de veículos e condições metereológicas. A qualidade de poluentes no ar pode ser identificada através de seu distinto comprimento de onda captado pelo sensor LIDAR.

\subsubsection{Infra-estrutura}

As aplicações relacionadas à infra-estrutura do sistema de transportes ocorrem nos níveis operacional, tático e estratégico, onde os corredores rodoviários, pontes, linhas férreas, pavimentos, estações, portos e 
aeroportos são os principais alvos. As informações mais comumente demandadas do sensoriamento remoto referem-se à localização, extração de redes rodoviárias, estado de conservação de vias e equipamentos, e mudanças ocorridas ao longo do tempo (Goodchild et al., 2001).

Shackelford e Davis (2003), através de imagens de alta resolução multiespectral, delinearam a rede rodoviária bem como classificaram a cobertura do solo na área urbana. A técnica de extração da rede rodoviária identifica iterativamente os segmentos de linha sobre a classificação da cobertura do solo urbano.

Fuller et al. (2003) desenvolveram um estudo utilizando imagem de satélite IKONOS II, juntamente com um MDE - Modelo Digital de Elevação, como insumos para um projeto de definição de rota para transporte de materiais perigosos. A elevada correspondência entre as feições extraídas da rodovia com os dados obtidos na banda pancromática leva-os a concluírem que as imagens IKONOS II possuem significativo potencial para alavancar o processo de mapeamento semi-automático de infra-estrutura de transportes.

Herold e Roberts (2005) utilizaram imagens hiperespectrais para analisar as condições do pavimento na avaliação da infra-estrutura de uma estrada asfaltada, tendo verificado que há correlação entre as medidas espectrais obtidas, tanto na imagem como em campo, com os índices de qualidade do pavimento.

Zhu et al. (2005) e Long e Zhao (2005) propõem metodologias semelhantes para extração automática das principais rodovias em imagens de alta resolução espacial, mais especificamente uma IKONOS II. Num primeiro estágio, ambos utilizam morfologia matemática para detecção das bordas e extração de objetos presentes no ambiente, mas considerados ruídos no delineamento das estradas, como árvores e carros. Todavia, enquanto os primeiros limitam-se à essa técnica, associada à outros conhecimentos das estradas, os segundos utilizam, de forma complementar, o processo de segmentação da imagem para extração das feições pretendidas. 
Na mesma linha, Nóbrega (2007) utiliza imagens do mesmo sensor para detecção da malha viária na periferia da cidade de São Paulo, numa área em que as vias caracterizam-se pela irregularidade geométrica e a diversidade de materiais utilizados na pavimentação. Como metodologia, propõe o uso da morfologia matemática aliada à classificação de imagem orientada a objeto.

A evolução dos trabalhos demonstra que o nível de detalhamento das informações extraídas cresce juntamente com a resolução espacial oferecida pelos diversos sensores utilizados, mas também é resultado de novas técnicas aplicadas na extração dos dados. 


\section{PROCESSAMENTO DIGITAL DE IMAGENS}

As imagens digitais geradas por sensores remotos são armazenadas e manipuladas em formato raster, em que cada mínimo elemento da forma é denominado pixel, sendo que este apresenta um valor quantificado, correspondendo a um valor físico de radiação eletromagnética, medido pelo sensor (TSO e MATHER, 2001). Crósta (1999) ressalta, entretanto, que este valor ou número digital (DN) de um pixel corresponde sempre à média da intensidade da energia refletida ou emitida pelos diferentes materiais presentes nesse pixel. Cada pixel é representado por um vetor padrão consistindo num conjunto de medições, cujo tamanho varia de acordo com a quantidade de bandas, conforme ilustrado na Figura 6 .

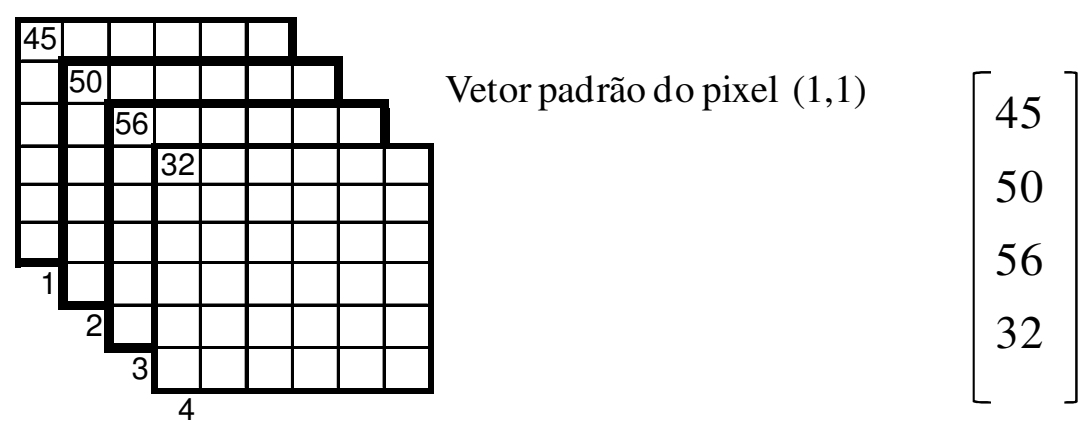

Figura 6 - Exemplo de distribuição de DN de um determinado pixel em 4 bandas espectrais.

\subsection{Sistema de interpretação de imagem}

Segundo Lillesand et al. (2004) é possível identificar objetos, de tamanho e forma variados, numa fotografia aérea ou imagem digital. Alguns objetos são facilmente identificados, enquanto outros só são possíveis dependendo grau de percepção visual e conhecimento do intérprete. A interpretação visual de imagens consiste na identificação de objetos e o repasse desta informação a outros. 
Utilizada há décadas para extração de informações de fotografias aéreas, Campbell (2005) coloca a interpretação visual num novo contexto de aplicabilidade, baseado em três pontos básicos: a) as habilidades aplicadas pelo foto-intérprete num papel fotográfico podem ser igualmente bem aplicadas numa imagem digital visualizada no computador; b) imagens de alta resolução espacial, com alto nível de detalhamento, não são mais produtos exclusivos de fotografias aéreas, mas também de modernos sensores orbitais e sub-orbitais, ampliando as possibilidades de aplicação das mesmas; e c) as técnicas de análise automatizada não são ainda capazes de extrair por completo toda a gama de informações provenientes das imagens de alta resolução espacial. Desta forma, deve-se explorar a sinergia entre as modernas técnicas de análise automática e o conhecimento do foto-intérprete para melhor extração de informações das imagens digitais.

O uso sistemático da interpretação tanto de fotografias aéreas como imagens de satélite requer a análise de características gerais das feições encontradas numa imagem, variando de acordo com a área estudada e a finalidade do trabalho (LILLESAND et al., 2004). Todavia, os critérios mais comumente utilizados são a forma, tamanho, padrão, textura, cor e tonalidade, sombra, posicionamento e associação (LILLESAND et al., 2004; CAMPBELL, 2005):

- Forma: refere-se ao formato geral, configuração ou contorno da feição. Algumas feições possuem contornos distintos caracterizando sua identidade ou função. É importante notar que a forma depende da perspectiva com que foi adquirida. A forma dos objetos vista ao nível do solo difere da extraída por sensores orbitais ou sub-orbitais, que induzem o efeito escala - permitindo a visualização de grandes feições - o que não seria possível numa perspectiva visual normal. A Figura 7 exemplifica essa distinção de contornos. 


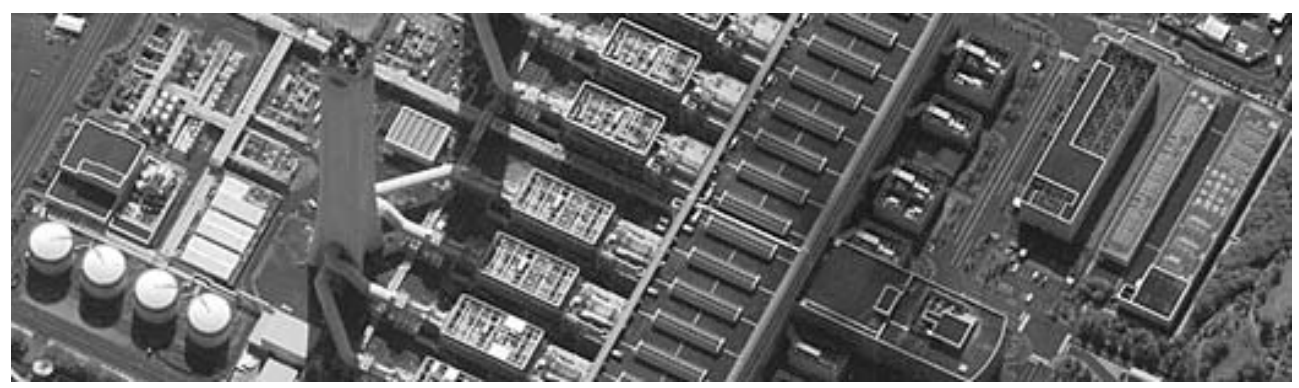

Figura 7. Imagem do satélite WorldView-1 de Yokohama, Japão.

Fonte: Digital Globe, disponível em

http://www.digitalglobe.com/index.php/197/WorldView-1+First+Images

- Tamanho: refere-se às dimensões da feição, seja em termos absolutos ou relativos. Tamanho relativo é obtido comparando-se o objeto com outras feições familiares possíveis de se encontrar nas redondezas e, geralmente, é suficiente para atribuir um objeto a uma determinada classe. Tamanho absoluto compreende o uso da imagem para extrair medições como cálculo de distância, volume e área.

- Tonalidade: corresponde ao brilho médio de uma área ou no caso de uma imagem colorida ou cor-infravermelho - $\mathrm{CIR}^{2}$, a cor dominante numa região. A tonalidade em imagens aéreas depende tanto da natureza do material imageado, do ângulo de observação e da iluminação. A Figura 8 exemplifica uma área agrícola com diferentes tonalidades de verde, relacionadas à diferentes culturas.

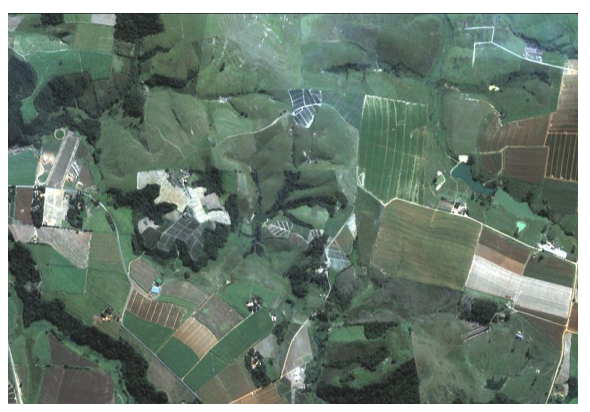

Figura 8. Imagem IKONOS II da região agrícola de Campinas, SP, Brasil.

\footnotetext{
${ }^{2}$ Do original "color infrared" - CIR (CAMPBELL, 2005).
} 
Fonte: Engesat, disponível em

http://www.engesat.com.br/?system=news\&eid=310

- Textura: corresponde à variação de tonalidade sobre a superfície ou à aparente rugosidade ou suavidade de um alvo em uma imagem. A textura em uma imagem é percebida por meio de micro-sombras provenientes de pequenas irregularidades na superfície. A Figura 9 exemplifica uma cena com textura mais rugosa, correspondendo à vegetação (em vermelho), em contraste com uma textura lisa da água (azul).

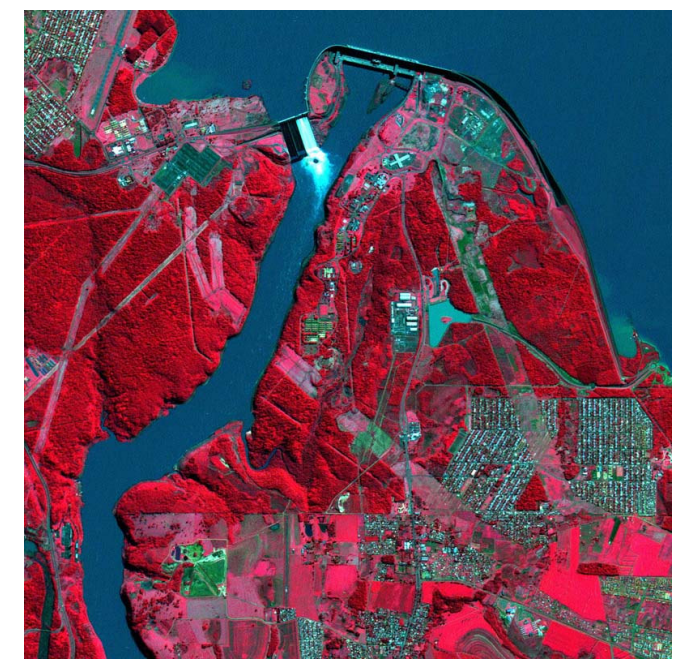

Figura 9. Imagem do satélite Resourcesat-1 da região de Foz do Iguaçu, PR - Brasil.

Fonte: Engesat, disponível em http://www.engesat.com.br/?system=news\&eid=310

- Sombra: refere-se às grandes sombras que revelam os contornos de um alvo projetado sobre uma superfície plana. A natureza da sombra está intrinsecamente ligada à natureza do objeto, ângulo de iluminação, perspectiva e declividade da superfície do terreno.

- Posicionamento: corresponde à localização do objeto com relação à topografia e drenagem. Muitas feições ocupam posições específicas em 
virtude de suas funcionalidades. Exemplificando, a rede telefônica procura pontos topograficamente mais altos para instalação de antenas, como a de microondas e telefonia celular.

- Associação: corresponde aos diferentes inter-relacionamentos espaciais, verificados entre feições, comumente formado pelas conexões funcionais entre os elementos em questão. Um exemplo seria associar a presença de piscina a uma residência, conforme pode ser ilustrado na Figura 10.

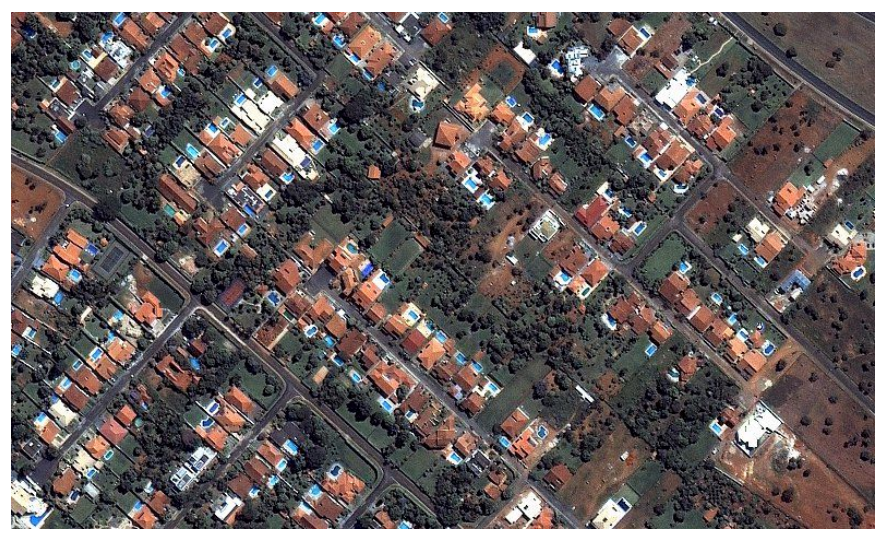

Figura 10. Imagem IKONOS II da zona residencial de Brasília.

Fonte: Engesat, disponível em

http://www.engesat.com.br/?system=news\&eid=310

- Padrão: refere-se aos diferentes arranjos espaciais das feições, indicando que um determinado alvo possui uma organização peculiar que o distingue dos demais. Um exemplo comum são os pivôs de irrigação, conforme ilustra a Figura 11. 


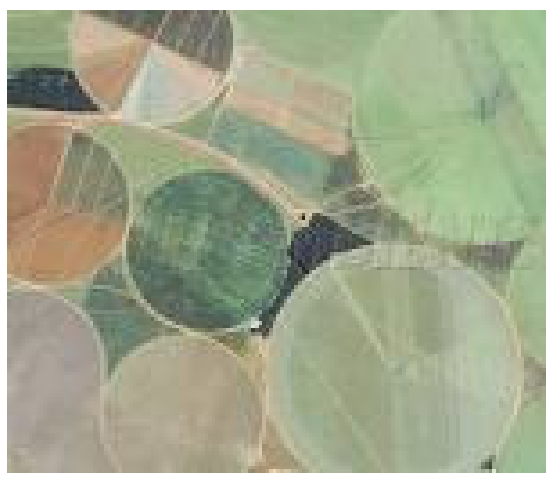

Figura 11. Imagem de área agrícola caracterizando a presença de pivôs de irrigação.

Fonte: Geoambiente, disponível em www.geoambiente.com.br/agronegocios.htm.

A interpretação visual de imagens pode auxiliar de diversas formas a extração de informações de uma imagem. A partir dela é possível extrair: a) medições como largura, comprimento, distância e volume; b) contagem ou listagem de itens visíveis numa cena; c) delineamento de diferentes regiões presentes e d) classificação.

A classificação atribui classes aos objetos, sendo comumente feita em três diferentes níveis de precisão: a) detecção, que é a indicação da presença ou não de uma feição na cena; b) reconhecimento, referindo-se a uma possível dedução feita pelo intérprete com base numa feição, atribuindo-a a uma classe em particular e c) identificação, quando o intérprete aloca a feição numa determinada classe específica (CAMPBELL, 2005).

A interpretação visual pode ser usada em conjunto com modernas técnicas de análise automática de imagens na busca de melhores resultados, como ocorre nos sistemas de interpretação de imagens baseados em conhecimento. Sistemas baseados em conhecimento são aqueles que modelam em um ambiente computacional o conhecimento do foto-intérprete emulando a sua capacidade de combinar dados de diferentes fontes e formatos na análise de imagens de sensores remotos (FEITOSA et al., 2005). 


\subsection{Processamento digital de imagens}

O processo de classificação de imagens digitais consiste na associação de cada pixel da imagem à uma determinada classe, correspondendo esta a um objeto real presente na área imageada. Cada pixel possui uma coordenada espacial x e y e um valor de digital number $\mathrm{DN}$, ou nível de cinza, que corresponde à radiância de um alvo no intervalo de comprimento de onda de uma banda espectral. O objeto identificado pode ser representado por um único pixel ou ainda por um conjunto de pixels adjacentes, formando uma entidade geográfica, como uma mata. Como resultado final, têm se um mapa temático com as diferentes classes que compõem a cobertura do solo.

Conforme Tso e Mather (2001), cada pixel possui um determinado padrão, sendo este constituído pela distribuição dos DNs nas várias bandas espectrais que compõem a imagem. A partir desta distribuição, pode-se representar os valores encontrados nas diferentes bandas num gráfico de " $n$ " dimensões, cujo número de eixos iguala-se à quantidade de bandas da imagem, chamado espaço de atributos. A Figura 12 exemplifica um espaço de atributos, em que $x 1, \times 2$ e $\times 3$ correspondem às três bandas, ou dimensões, de uma imagem e w1, w2 e w3 as classes identificadas.

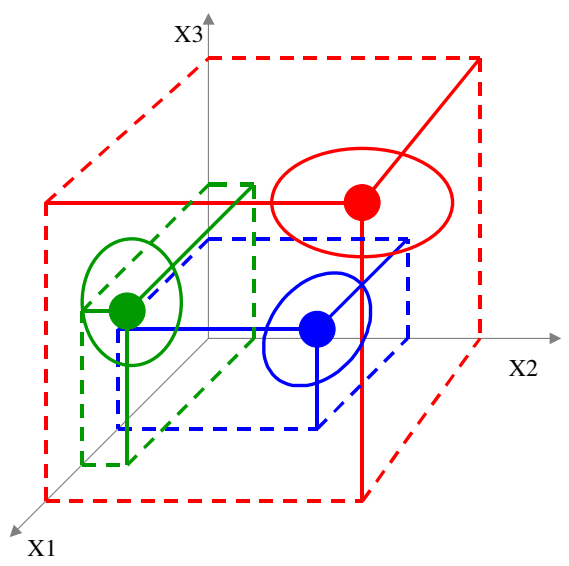

Figura 12 - Classes no espaço de atributos. 
O gráfico resultante é denominado espaço de atributos, ou seja, representação gráfica das freqüências de distribuição de intensidade das bandas de uma imagem multiespectral (CRÓSTA, 1999).

O processo de classificação envolve a divisão deste espaço de atributos em regiões homogêneas, cujas bordas são definidas de acordo com determinados critérios.

\subsubsection{Classificadores tradicionais}

Consideram-se tradicionais as técnicas de classificação cujo critério de decisão, para alocar um pixel numa determinada classe, baseia-se tão somente na distribuição dos níveis de cinza nas diversas bandas espectrais que compõem a imagem. A classificação dos pixels é feita através de métodos matemáticos - estatísticos e determinísticos - e são classificadas em supervisionadas e não-supervisionadas. A diferença básica entre ambas é que a primeira utiliza-se de amostras de treinamento para cada classe que se pretende identificar, enquanto a segunda procura agregar os pixels em classes, de acordo com seus valores de cinza (LILLESAND et al, 2004).

\subsubsection{Classificação supervisionada}

A classificação supervisionada baseia-se na existência de um conhecimento prévio da região e das classes, identificando previamente as diversas classes de materiais que se pretende classificar na imagem. Segundo Lillesand et al. (2004) esta modalidade compreende três procedimentos básicos, esquematizados na Figura 13. O primeiro consiste no treinamento, em que se identificam áreas amostrais representativas, incluindo a descrição numérica dos atributos espectrais, para cada classe. O segundo procedimento é a classificação propriamente dita, em que cada pixel é rotulado pertencente a uma determinada classe de acordo com padrões de similaridade. $O$ terceiro procedimento é o resultado da 
classificação que pode ser utilizado de formas distintas, como mapas temáticos, tabelas estatísticas ou ainda dados digitais, como insumos para um SIG.

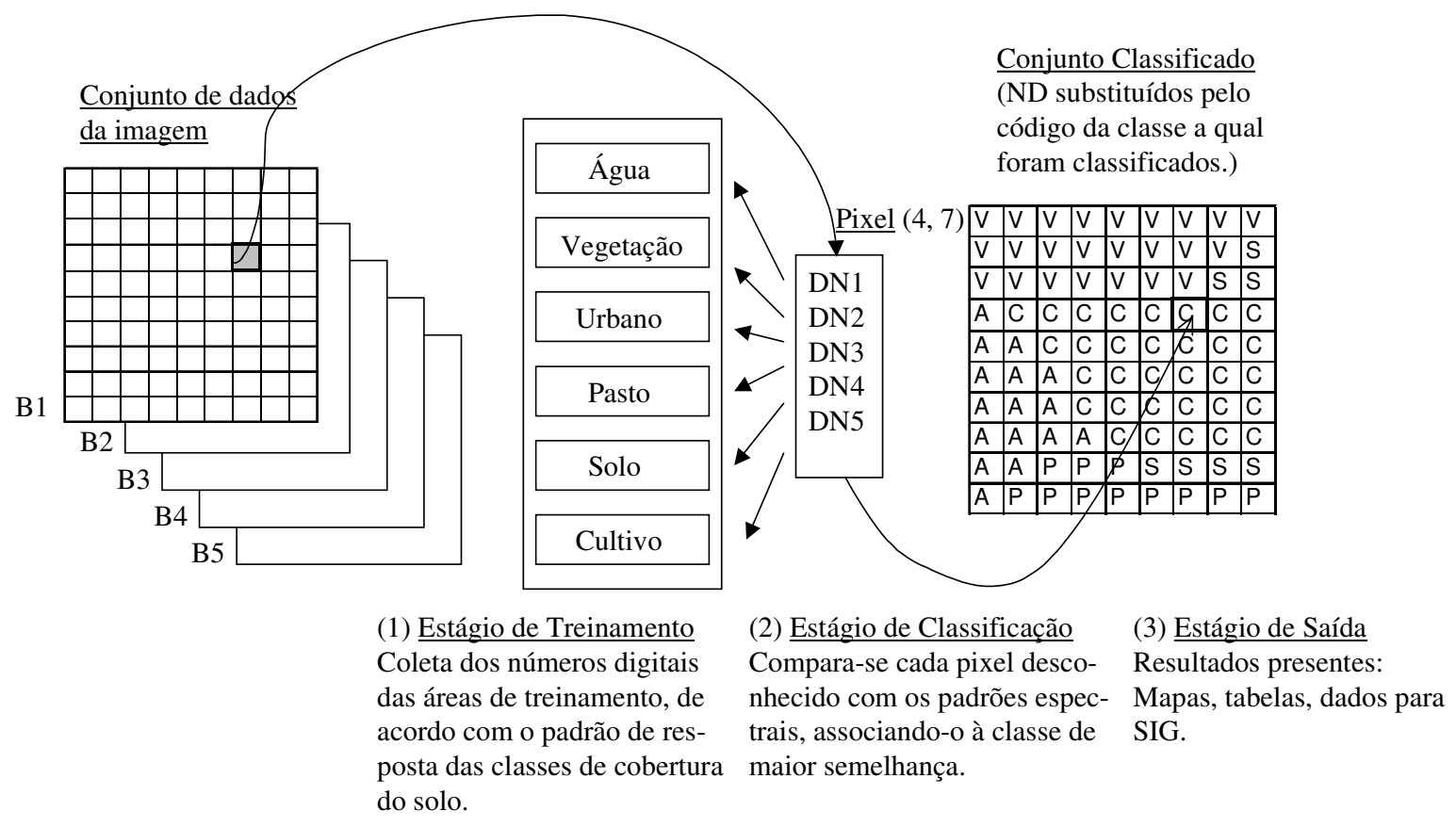

Figura 13 - Esquema básico da classificação supervisionada.

Fonte: Adaptado de Lillesand et al., 2004.

Para Tso e Mather (2001), esta técnica é a mais utilizada por conferir maior precisão na definição das classes e maior acurácia quando comparada à classificação não supervisionada. Entre as ferramentas matemáticas utilizadas, três são mais freqüentemente encontradas: a) método do paralelepípedo, b) método da mínima distância e, c) método da máxima verossimilhança, mais conhecido como MaxVer.

O método do paralelepípedo consiste basicamente na definição de uma área geométrica em forma de paralelepípedo, dentro do espaço de atributos, cujos limites são definidos pelos valores máximos e mínimos dos pixels de uma determinada amostra de treinamento. A regra de decisão é 
relativamente simples, atribui-se uma determinada classe ao pixel se o valor do mesmo encontrar-se dentro dos limites do paralelepípedo daquela. A vantagem deste método está na sua rapidez e facilidade de implementação, mas erros podem acontecer quando um pixel situa-se dentro de mais de um paralelepípedo, ou ainda, na situação inversa, não pertence a nenhuma classe assinalada (TSO e MATHER, 2001). A Figura 14 demonstra o esquema de classificação do método do paralelepípedo.

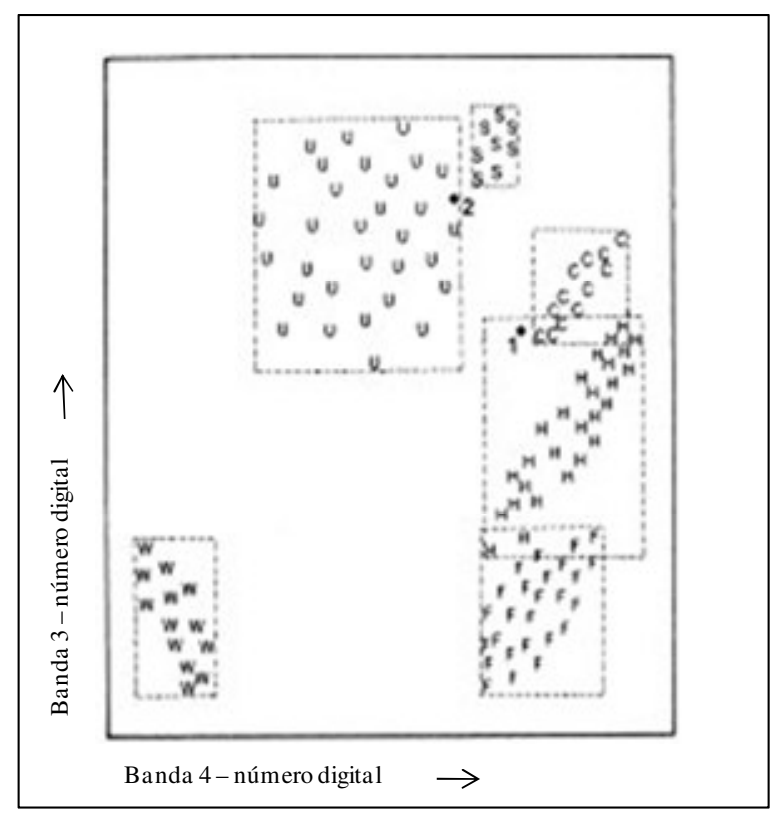

Figura 14 - Esquematização da classificação pelo método do paralelepípedo.

Fonte: Adaptado de Lillesand et al., 2004.

O método da mínima distância considera a média estatística para cada uma das classes, em cada uma das bandas espectrais, classificando cada pixel à classe cuja média for mais próxima a ele (CRÓSTA, 1999), baseando-se em distância Euclidiana ou na distância de Mahalanobis, sendo a primeira no espaço de atributos enquanto a segunda refere-se à distribuição de freqüência. Este classificador é matematicamente simples e computacionalmente eficiente, embora seu embasamento teórico não seja 
tão forte como o de máxima verossimilhança, abordado na seqüência (TSO e MATHER, 2001). A Figura 15 esquematiza a classificação baseada na mínima distância.

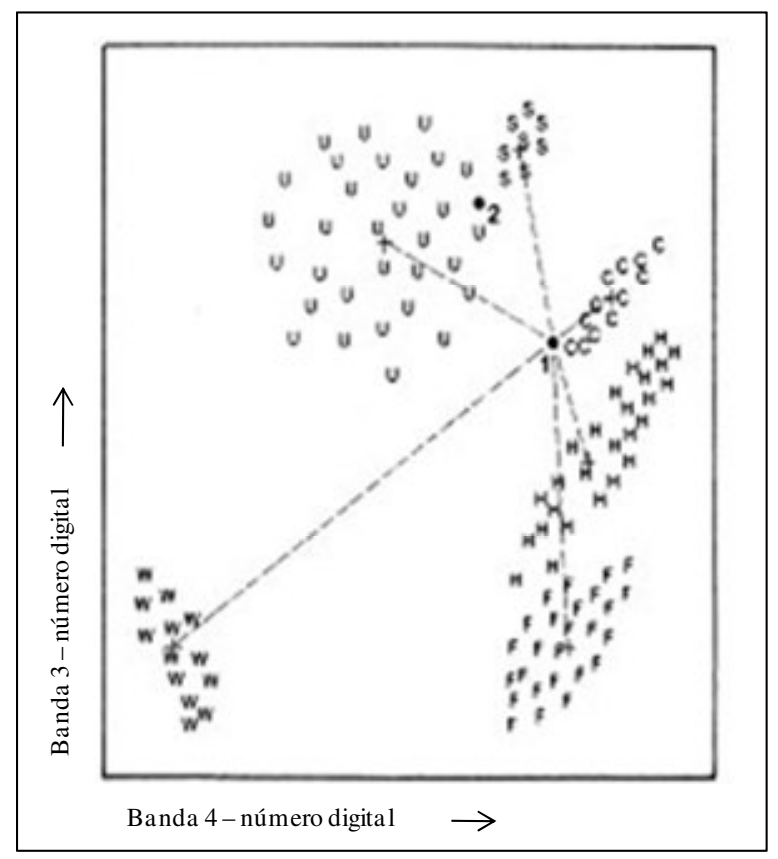

Figura 15 - Esquematização da classificação pela mínima distância.

Fonte: Adaptado de Lillesand et al., 2004.

O método da máxima verossimilhança é o mais utilizado e também o mais complexo dos três apresentados, considerando os valores de variância e covariância do padrão de resposta de cada categoria espectral para classificação de um determinado pixel. Para tanto, supõem-se que os pixels amostrais de cada classe encontram-se em distribuição normal ou Gaussiana, onde a distribuição de cada classe de padrão de resposta pode ser descrita através do vetor média e matriz de covariância. Desta forma, verifica-se a probabilidade de um certo pixel pertencer a cada uma das classes amostradas, sendo então classificado na que obtiver maior probabilidade (LILLESAND et al., 2004). Para duas classes (1 e 2) com distribuição de probabilidade distintas, as distribuições representam a probabilidade de um "pixel" pertencer a uma ou outra classe, dependendo da 
posição do "pixel" em relação a esta distribuição. Ocorre uma região onde as duas curvas sobrepõem-se, indicando que um determinado "pixel" tem igual probabilidade de pertencer às duas classes. Nesta situação se estabelece um critério de decisão a partir da definição de limiares. Lillesand et al. (2004) atentam para principal desvantagem do método que reside na complexidade computacional que o mesmo demanda para classificação de cada pixel, especialmente quando se trabalha com elevado número de bandas e de classes a serem identificadas. A Figura 16 representa a classificação pela máxima verossimilhança.

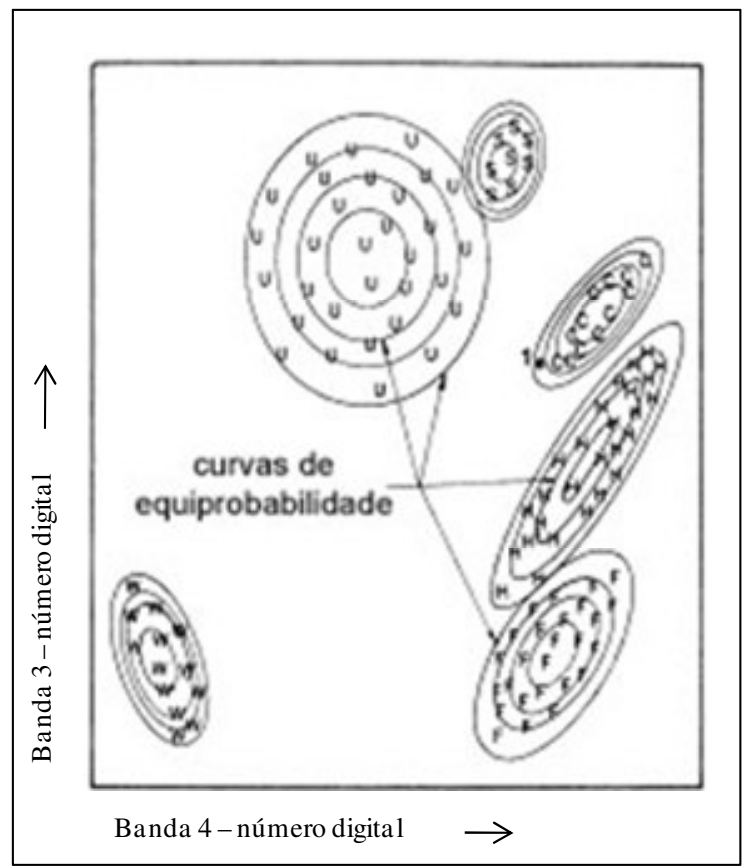

Figura 16 - Esquematização da classificação pela máxima verossimilhança. Fonte: Adaptado de Lillesand et al., 2004.

\subsubsection{Classificação não-supervisionada}

A classificação não-supervisionada pode ser utilizada quando não há conhecimento prévio suficiente, da área analisada, para que o analista possa definir classes e suas respectivas amostras. Desta forma, o próprio software utilizado, valendo-se de determinados algoritmos, é capaz de distinguir os 
agrupamentos de classe no espaço de atributos, cabendo ao analista sinalizar a quantidade de classes a serem identificadas. A definição das classes só se dá após a classificação ter sido concluída (MATHER, 2005).

Há uma série de algoritmos de agrupamento ou "clustering" (termo em inglês) capazes de identificar agrupamentos ou "clusters" espectrais dentro do espaço de atributos, sendo o K-média e o ISODATA Iterative Self-Organizing Data Analysis, dois dos algoritmos largamente utilizados.

O K-média consiste em duas etapas distintas: a) determinação de centróides de cada classe - média da posição das amostras de uma classe - ao redor dos quais se originam os grupos ou "clusters", sendo que o número destes é previamente determinado pelo analista e, b) a associação dos pixels desconhecidos à classe cujo centróide esteja mais próximo. Após todos os pixels terem sido classificados desta forma, recalcula-se a média que servirá de base para nova classificação. Esse processo se repete continuamente até que não haja mais mudanças significativas na posição da média das classes entre as sucessivas iterações do algoritmo, ou ainda, que tenha se atingido o número de iterações fixado pelo analista (LILLESAND et al., 2004).

O ISODATA consiste numa variação do K-média, apresentando operações adicionais como fusão, divisão e exclusão de classes espectrais. Exemplificando, se a distância entre dois pontos médios de duas determinadas classes for menor que uma distância mínima predefinida, estas classes são fusionadas. Da mesma forma, se o desvio padrão de uma determinada classe for superior ao valor máximo predefinido, a classe é dividida em duas (LILLESAND et al., 2004).

\subsubsection{Limitações dos classificadores tradicionais}

Os classificadores tradicionais classificam a imagem pixel a pixel utilizando apenas a resposta espectral dos materiais imageados como 
critério classificatório e a condição de que cada pixel pertence a uma única classe.

O ambiente urbano é formado por uma considerável diversidade de materiais, podendo apresentar padrões de resposta distintos, mas que acabam se fundindo num único pixel - como vegetação e pavimento consistindo no chamado pixel misto. Embora o advento das imagens de alta resolução espacial tenha reduzido esta limitação, os classificadores tradicionais também apresentam limitações para distinguir materiais distintos, mas de resposta espectral semelhante, como é o caso do asfalto e do amianto, mesmo que estes se encontrem em pixels distintos. Conforme Pinho et al. (2005) os classificadores tradicionais tornaram-se limitados em áreas urbanas devido à sobreposição de classes em seu espaço de atributos.

Outros estudos (SHACKELFORD e DAVIS, 2003; LALIBERTE et al., 2004; HE et al., 2005; QUINTANILHA e SILVA, 2005) apontam para o uso de novas técnicas de processamento de imagem, capazes de extrair eficazmente todo o potencial de dados que as imagens de alta resolução espacial apresentam, incluindo variáveis como contexto, forma e textura.

Para Ehlers (2007) os dados de sensoriamento remoto de alta e altíssima resolução demandam novos procedimentos baseados numa regionalização ou segmentação inteligente de dados de imagem e que utilizem procedimentos de base contextual.

\subsubsection{Classificação por regiões}

A classificação por regiões apresenta-se como um método alternativo aos métodos tradicionais de classificação, pois utiliza tanto a informação espectral de cada pixel como também a informação espacial que envolve a relação entre os pixels e sua vizinhança. Estes classificadores procuram simular o comportamento de um foto-intérprete, ao reconhecer áreas homogêneas de imagens, baseados nas propriedades espectrais e espaciais de imagens. (INPE, 2007). 
Um dos algoritmos utilizados na classificação por regiões é o Bhattacharyya, que estima a separabilidade estatística para duas classes espectrais, ou, mais corretamente, mede a probabilidade de uma classificação mais correta (MATHER, 2005). Para cada região é calculada a distância de Bhattacharrya entre duas classes, $\varpi_{1}$ e $\varpi_{2}$, conforme equação 1. A distância é computada para cada par de classe dado um número $m$ de feições. Todas as possíveis combinações são testadas e, ao término do processo, a região avaliada será atribuída à classe que apresentar menor distância em relação à outra classe (MATHER, 2005).

$\mathrm{B}=\frac{1}{8}\left(x_{1}-x_{2}\right)^{\mathrm{T}} \frac{S_{1}+S_{2}}{2}\left(x_{1}+x_{2}\right)+\frac{1}{2} \ln \frac{\left(s_{1}-s_{2}\right) / 2}{\left|S_{1}\right|^{0.5}\left|S_{2}\right|^{0.5}}$

onde:

$x_{1}$ e $x_{2}=$ vetores de média das classes $\varpi_{1}$ e $\omega_{2}$, respectivamente

$S_{1}$ e $S_{2}=$ matrizes de covariância das classes $\varpi_{1}$ e $\omega_{2}$, respectivamente

$\mathrm{T}=$ matriz transposta

In = logaritmo neperiano

Todavia, a classificação por regiões demanda um processamento antecedente pelo qual as regiões são identificadas e devidamente delineadas.

\subsubsection{Segmentação}

A segmentação consiste na da divisão de uma imagem em regiões que melhor representam os objetos de interesse numa cena, sendo que os atributos de cada região, como área, formato, parâmetros estatísticos e texturas podem ser extraídos e adicionados na análise dos dados (BINS et al., 1996). A disponibilidade de imagens de alta resolução espacial e suas características, como alto nível de detalhe e variância espectral, popularizou o uso da segmentação, tornando-a uma variante comum para interpretação 
de dados, superando algumas das limitações da análise pixel-a-pixel, baseada unicamente em atributos espectrais (MEINEL e NEUBERT, 2002).

A divisão da imagem é feita por algorítimos baseados em uma das seguintes propriedades básicas de valores de níveis de cinza dos pixels: descontinuidade e similaridade (GONZALEZ e WOODS, 2000).

Através da descontinuidade procura-se dividir a imagem baseando-se em mudanças bruscas nos níveis de cinza dos pixels. Tais mudanças podem ser detectadas com base em pontos isolados, linhas isoladas e ainda bordas na imagem, sendo esta última a mais utilizada para identificação de descontinuidades significantes nos níveis de cinza.

Uma borda pode ser definida como o limite entre duas regiões com propriedades distintas de nível de cinza (GONZALEZ e WOODS, 2000) e sua extração é possível aplicando-se um algoritmo que, valendo-se dos gradientes de cinza da imagem original, gera uma imagem de intensidade de borda.

Já o critério de segmentação por similaridade de níveis de cinza dos pixels pode ocorrer por limiarização, crescimento de regiões e divisão e fusão de regiões. A limiarização consiste na divisão do histograma em um limiar, podendo este ser único ou múltiplo, a partir do qual a imagem é varrida e cada pixel é rotulado como sendo do fundo da imagem ou de um dos objetos que a compõe.

O crescimento de regiões consiste no agrupamento de pixels ou subregiões em regiões maiores, sendo que estas devem atender às seguintes condições: a) cada pixel deve pertencer a uma região, b) os pixels agrupados numa dada região devem ser conexos, c) as regiões devem ser disjuntas (GONZALES e WOODS, 2000). Este tipo de segmentação parte de um conjunto de pixels iniciais, a partir dos quais crescem as regiões, anexando a cada pixel inicial outros pixels que apresentem propriedades similares, como nível de cinza, textura e cor.

A divisão e fusão de regiões, como o próprio nome sugere, consistem na divisão ou fusão de regiões, identificadas pelo processo anterior, desde que atendidas as mesmas condições. 
A segmentação de imagens é um processo preliminar para reconhecimento de padrões (INPE, 2007). Como os objetos identificados numa imagem podem ser delineados pela segmentação, o número de elementos a serem classificados posteriormente é reduzido significativamente. Desta forma, a qualidade da classificação está relacionada diretamente à qualidade da segmentação (MEINEL e NEUBERT, 2002).

Meinel e Neubert (2002) avaliaram o desempenho da função de segmentação de imagem presente em sete programas disponíveis na época. O desempenho geral do software SPRING - desenvolvido pelo Instituto Nacional de Pesquisas Espaciais (INPE) e usado neste trabalho - foi classificado entre os melhores.

\subsection{União de dados de Sistema de Informação Geográfica - SIG e sensoriamento remoto}

Burrough e McDonnel (1998) definem SIG como um poderoso sistema de ferramentas que permite a aquisição, armazenamento, manipulação, transformação e visualização de dados espaciais do mundo real para um determinado propósito. Dados geográficos, ou espaciais, representam fenômenos do mundo real em termos de: a) seu posicionamento em relação a um sistema de coordenadas conhecido, b) seus atributos relacionados ao posicionamento e c) seu inter relacionamento espacial com demais entes.

A disponibilidade cada vez maior de dados de SIG abre novas e potenciais opções para avaliação de dados de sensoriamento remoto (SCHIEWE e TUFLE, 2006). Conforme Blaschke et al. (2007) as funcionalidades do SIG podem ser integradas diretamente no processo de classificação da imagem, fornecendo informações relevantes sobre os objetos ou regiões identificados na imagem, de forma a garantir que a classificação final tenha um resultado melhor do que se utilizasse apenas informações espectrais. 
Informações sobre os arranjos espaciais podem ser obtidas analisando-se as relações topológicas, tais como: a) conectividade, quando dois objetos estão interligados por um ponto em comum, b) adjacência, quando dois objetos compartilham de um limite comum, c) disjunção, quando não há limites em comum entre os objetos e, d) contingência, quando um ou mais objetos estão contidos em algum outro. A Figura 17 ilustra algumas relações topológicas entre áreas.

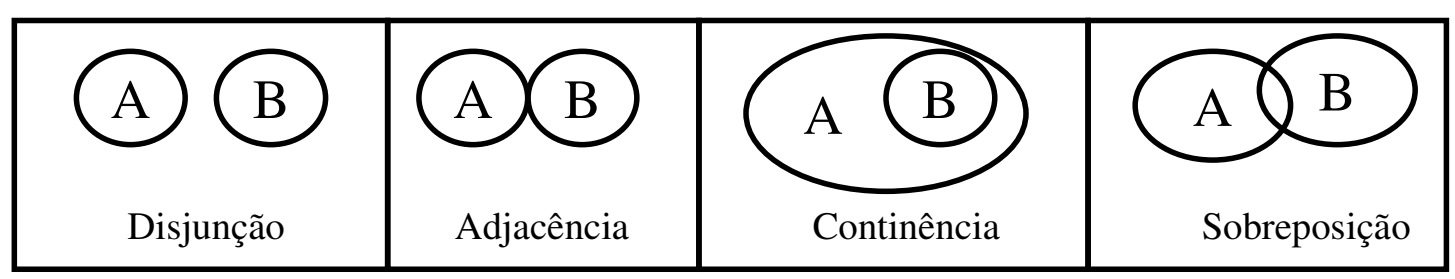

Figura 17. Exemplos de relações topológicas entre áreas.

Informações sobre o contexto podem ser extraídas através de análises de relacionamentos espaciais entre os objetos, exemplificando que uma classe $A$ só existe se for adjacente à classe $C$, ou que $B$ só existe se estiver contida em C (Antunes, 2003).

Schiewe e Tufle (2006) atentam para a importância que dos procedimentos baseados em regiões têm na interpretação integrada de dados SIG e de sensoriamento remoto, mas que ainda demandam desenvolvimento de procedimentos adicionais devido à complexidade da análise das imagens de alta resolução, especialmente por conta da heterogeneidade dos objetos a serem extraídos. 


\section{MATERIAIS}

\section{1 Área de abrangência total da pesquisa}

O projeto desenvolve-se sobre parte da Linha F da CPTM, com 38,8 km de extensão, cruzando as zonas central e leste da capital paulista, estendendo-se até Itaquaquecetuba e Poá. A Figura 18 apresenta a representação da Linha F e sua interligação com outras linhas da CPTM.

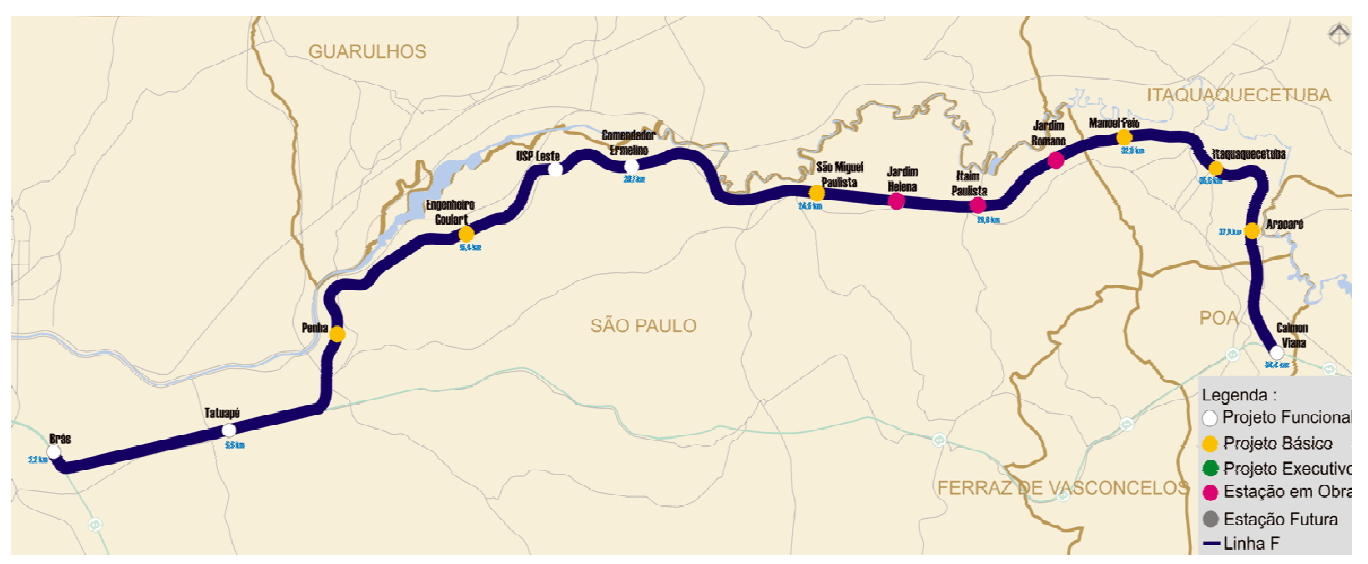

Figura 18 - Esquematização das linhas de transporte metroferroviário em

São Paulo.

Fonte: CPTM (2007).

Em função do volume de dados envolvidos, o projeto concentra-se numa área limitada pelas estações Comendador Ermelino e Itaim Paulista, localizada entre as latitudes 2328'19"S e 2330'35”S e longitudes 46⒉ $04^{\prime \prime} \mathrm{W}$ e 4623 $43^{\prime \prime W}$. Este trecho estende-se por cerca de $8,5 \mathrm{~km}$ e, conforme pode ser visto na Figura 19, é atendido também pela estação São Miguel Paulista, havendo projeto para instalação futura da estação Jardim Helena. 


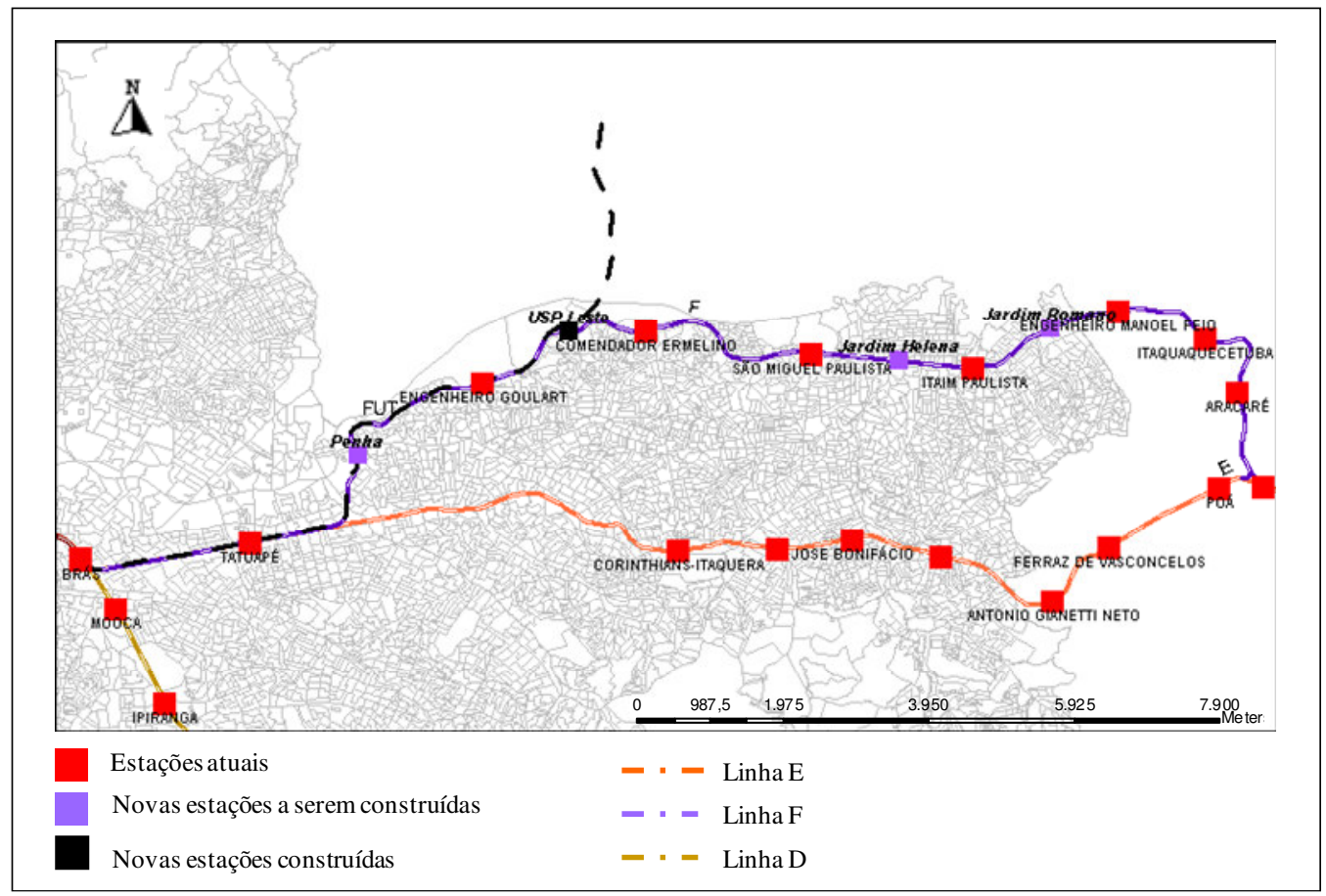

Figura 19 - Localização da área de estudo, no detalhe a Linha F.

Fonte: CPTM (2007).

A região é densamente povoada, inclusive com presença de diversas favelas, algumas juntas à linha férrea, conforme ilustra a Figura 20. De acordo com o Mapa de Exclusão/Inclusão Social da Prefeitura Municipal de São Paulo, a região apresenta índices de $-0,4$ a -0,6, numa escala de 0 a 1 , representando seu grau de exclusão social, calculada de acordo com as dimensões autonomia, qualidade de vida, desenvolvimento humano, eqüidade, cidadania, democracia e felicidade. Conclui-se daí, que a região é predominantemente povoada por uma população carente de infra-estrutura de naturezas diversas, incluindo transporte.

De acordo com a Lei 13.885, de 25 de agosto de 2005, mais conhecida como Lei de Zoneamento, que dispõe sobre o uso e ocupação do solo do município, há predomínio da Zona 2 (zona de uso predominantemente residencial de densidade demográfica baixa). Todavia, próximo ao eixo da linha, mais especificamente em torno das estações São Miguel Paulista e Itaim Paulista, destaca-se a presença das Zonas 3 e 6 (zona de uso predominantemente residencial, de densidade demográfica 
média e zona industrial, respectivamente). Diferentemente, a estação Comendador Ermelindo destaca em seu entorno a presença de Zona 8 (usos especiais), referindo-se ao Parque Ecológico do Tietê e Zona 4 (Zona de uso misto, de densidade demográfica média - alta), conforme pode ser visto na Figura 20.

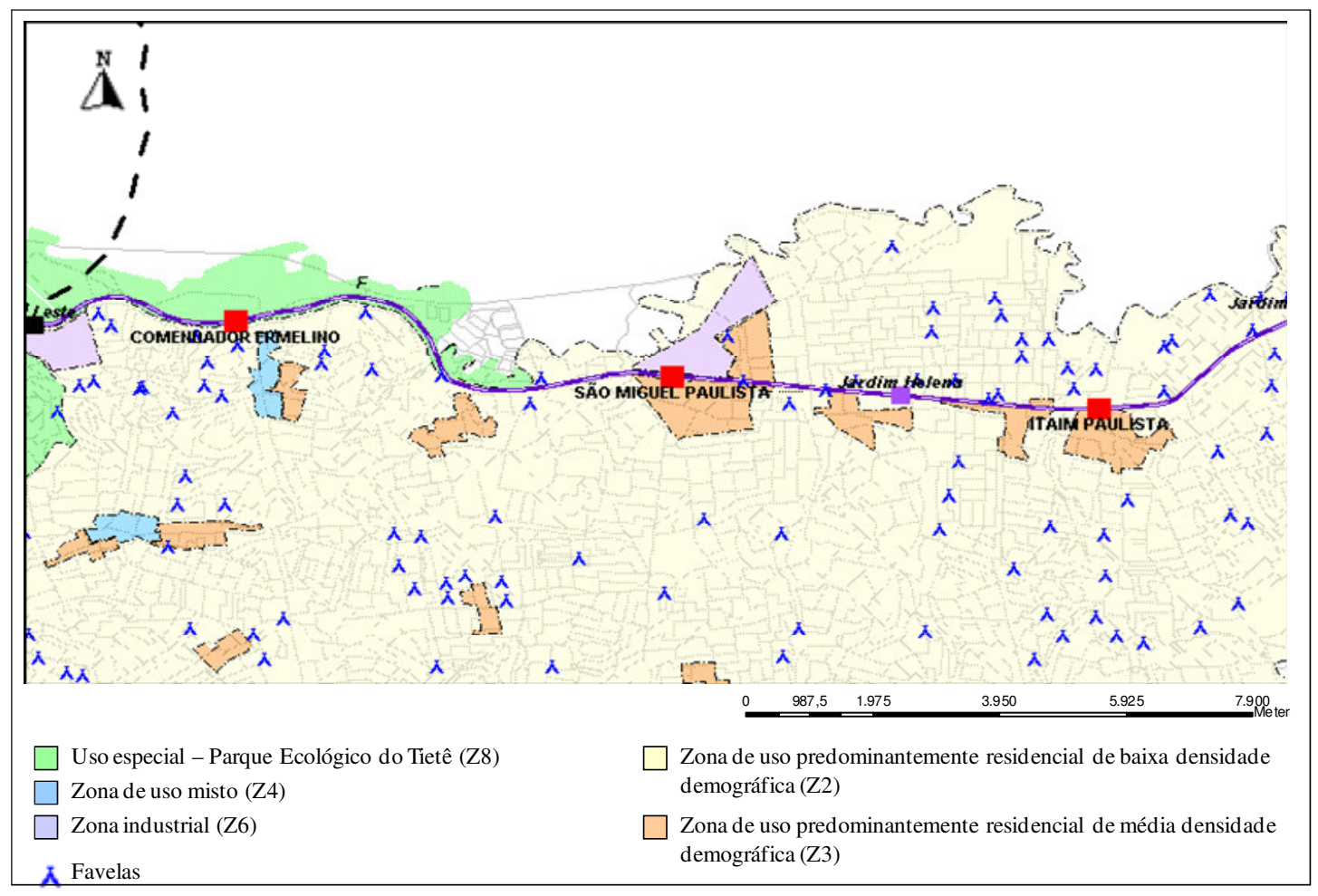

Figura 20 - Área de estudo com informações sobre a Lei de Zoneamento e características demográficas.

\subsection{Linha F}

A linha F foi construída em 1920, mas inaugurada apenas em 1934, oferecendo serviços suburbanos para bairros então considerados "rurais", ao sul do Rio Tietê. Com o tempo, as regiões de Ermelino Matarazzo, São Miguel Paulista e Itaim Paulista, além da cidade de Itaquaquecetuba, se tornaram localidades densamente habitadas, especialmente por uma população de renda mais baixa. 
A linha $\mathrm{F}$ enquadra-se nos chamados serviços de trens de subúrbio, denominação dada às linhas férreas, inicialmente utilizadas para transporte de cargas, mas que a partir da década de 30 passaram a assumir também o transporte da população instalada ao longo de seu eixo, dita suburbana. Caracteriza-se, entre outras coisas, por estações espaçadas de quatro a oito quilômetros, em média (SILVA, 2005).

Tendo seu ponto de partida na estação Brás, a linha percorre cerca de $38 \mathrm{~km}$, sendo atendida atualmente por 10 estações, cujo espaçamento médio é de $4 \mathrm{~km}$, velocidade média de $44 \mathrm{~km} / \mathrm{h}$, transportando cerca de 135 mil passageiros/dia, cortando os municípios de São Paulo, Itaqüaquecetuba e Poá.

Em 13 de março de 2007, a CPTM anunciou a captação de recursos para investimento em infra-estrutura por meio de um Fundo de Investimento em Direitos Creditórios - Não Padronizado (FIDC-NP). O aporte será empregado nas linhas $\mathrm{C}$ e $\mathrm{F}$, visando o aumento de capacidade de forma a atender uma demanda reprimida, redução do intervalo entre os trens e melhoria das condições de conforto e segurança dos passageiros (CPTM, 2007). Entre as melhorias, destaca-se a construção de novas estações, como Penha, Jardim Paulista, Jardim Helena e Jardim Romano na linha F.

\subsection{Imagem de satélite}

As imagens utilizada nessa pesquisa são produtos CARTERRA Ortho Precision, obtidos a partir de um preciso modelo digital de elevação (MDE). Essas imagens são derivadas das imagens IKONOS II originais, as quais sofreram uma série de processamentos como a fusão entre bandas e a ortorretificação, correspondendo ao mais alto padrão de imagens oferecido pela empresa norte-americana Space Imaging LLC, responsável pelo lançamento do satélite IKONOS II, e pela aquisição e comercialização de suas imagens. A ortorretificação permite 0 uso das imagens como fonte direta de informação métrica, possibilitando o rearranjo dos elementos presentes na imagem em sua verdadeira posição e permitindo a execução de medições. 
Os produtos CARTERRA são elaborados a partir da fusão da banda pancromática e de combinações coloridas das bandas NIR, Red, Green e Blue (infravermelho próximo, vermelho, verde e azul, respectivamente), para a composição da cena multiespectral com resolução espacial de 1 metro. Posteriormente, a imagem multiespectral passa pelo processo de ortorretificação, preferencialmente tomando como base um modelo digital de elevação preciso (NÓBREGA, 2007).

As imagens foram adquiridas pelo Instituto Geológico da Secretaria do Meio Ambiente do Estado de São Paulo, sendo que o imageamento original data de outubro de 2002 e a abrangência dessa coleção de imagens inclui os 39 municípios da Região Metropolitana de São Paulo, conforme demonstrado na Figura 21.

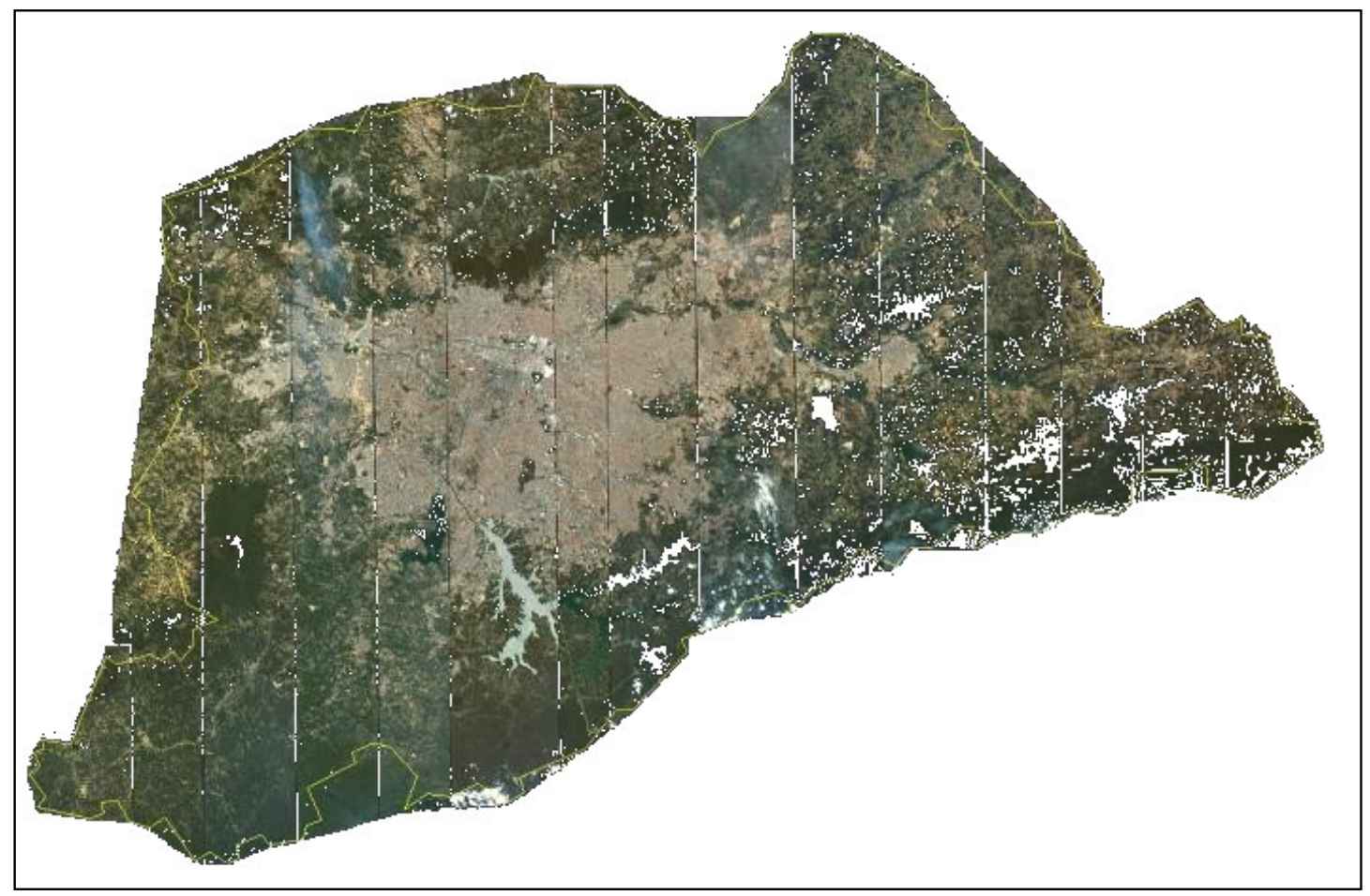

Figura 21 - Cobertura de imagens IKONOS II sobre a RMSP.

Fonte: FUNCATE, 2004.

Nóbrega (2007) ressalta ainda que as imagens CARTERRA do Instituto Geológico da Secretaria do Meio Ambiente do Estado de São Paulo foram compiladas utilizando um modelo digital de elevação extraído de 
cartas com escala 1:10.000 da EMPLASA (Empresa Paulista de Planejamento Metropolitano S.A.) e empregado pela Space Imaging $L L C$ no processamento das imagens finais.

\subsection{Dados SIG}

Foram utilizadas as bases de dados digitais de Quadras e Logradouros do município de São Paulo, integrantes do programa São Paulo Protege

(http://portal.prefeitura.sp.gov.br/secretarias/assistencia_social/menu_secret aria/sp_protege), fornecidas ao Laboratório de Geoprocessamento. As duas bases estão em escala 1:2.000 e sistema de projeção Latitude / Longitude. A Fig 22 ilustra a sobreposição das bases numa pequena área do projeto.

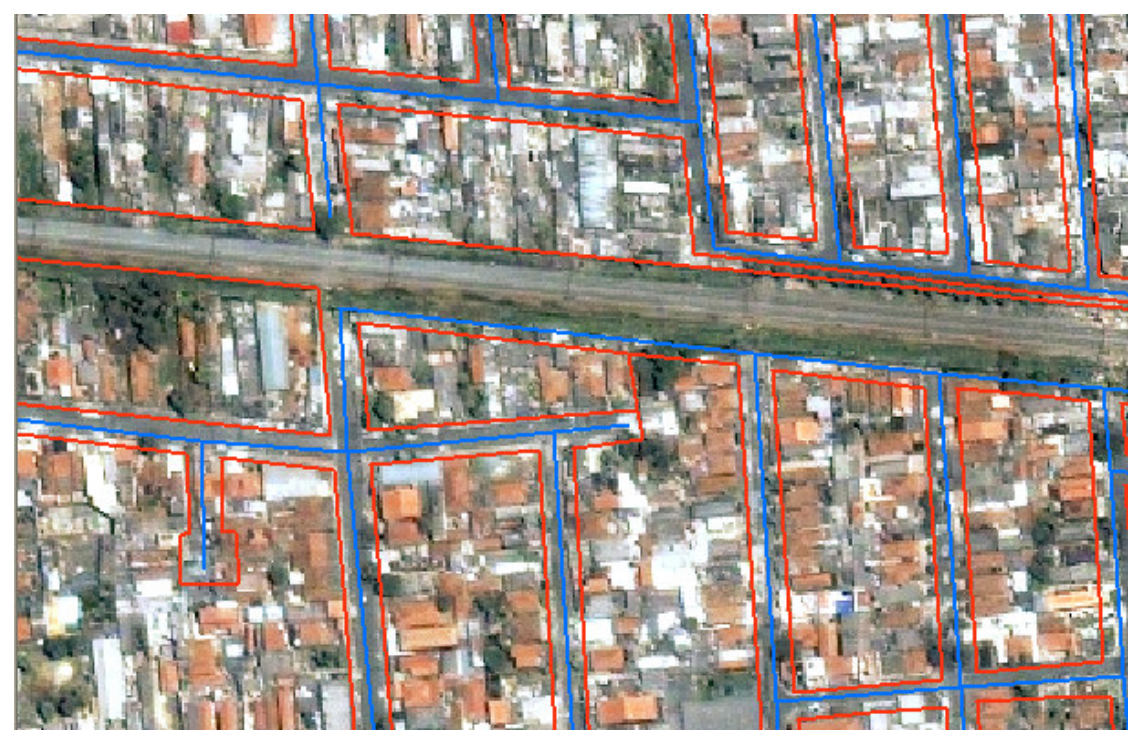

Figura 22 - Sobreposição das bases digitais de Quadra (vermelho) e Logradouro (azul) na imagem IKONOS II em parte da área de estudo.

\subsection{Softwares}

Diversos softwares foram empregados ao longo dos processos de preparação, classificação e análise de resultado, de forma a explorar o 
potencial das ferramentas disponíveis. Desta forma, abaixo encontram-se relacionados os programas e funções utilizadas:

- ENVI 4.2: Utilizado para preparação dos dados (pré-classificação), correspondendo às funções de mosaicagem e balanceamento das imagens;

- Spring 4.2: Utilizado para recorte da área de estudo, a segmentação e classificação por regiões;

- ArcGIS 9.1: Utilizado para integração dos dados SIG com a classificação por regiões. Por meio dele foi possível aplicar as regras para aprimoramento da classificação inicial da imagem. 


\section{METODOLOGIA}

A Figura 23 ilustra os processos seguidos para obtenção do mapeamento da cobertura do solo em torno da linha férrea. A metodologia proposta baseou-se em quatro processos macros: a) pré-processamento, compreendendo atividades de preparação das imagens; b) delimitação da área de estudo, visando a otimização do processamento da imagem; c) processamento, compreendendo a identificação visual dos materiais contidos na cena, segmentação, classificação por regiões e pósclassificação e; d) avaliação da classificação obtida.

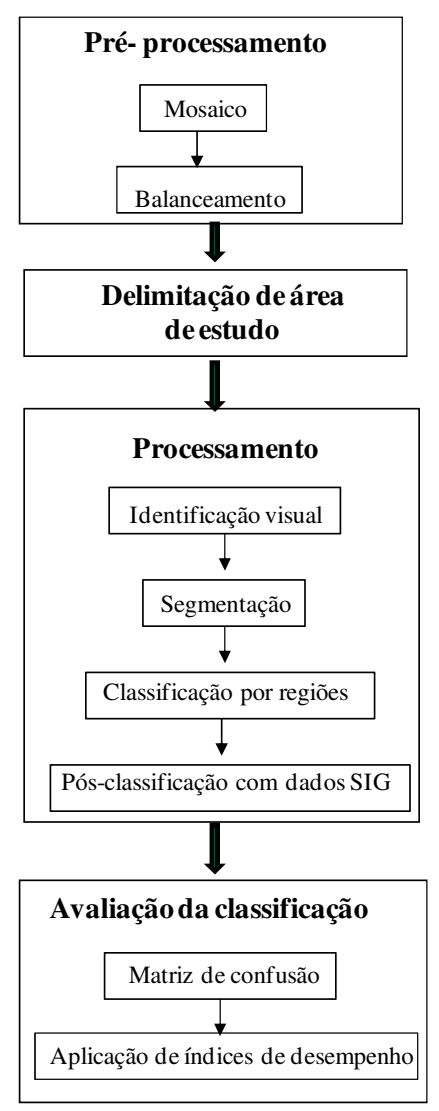

Figura 23 - Esquema da metodologia proposta.

\subsection{Pré-processamento}


Nesta fase procurou-se adaptar as imagens disponíveis para viabilizar seu uso e aplicação para o objetivo proposto, valendo-se de recursos como mosaico e balanceamento. Estas operações se fizeram necessárias em virtude de se contar inicialmente com seis cenas IKONOS II necessárias à cobertura da linha $\mathrm{F}$ em toda sua extensão, representando uma carga de dados incompatível com a capacidade de processamento disponível.

A coleção de imagens do Instituto Geológico da Secretaria do Meio Ambiente do Estado de São Paulo, utilizada nesse projeto, recobrindo toda a Região Metropolitana de São Paulo, encontra-se estruturada de tal forma, que as áreas cobertas foram dividas em folhas, sendo estas compostas por quatro imagens independentes, correspondendo a cada uma das quatro bandas do sensor. A disposição destas folhas pode ser observada na Figura 24. Uma vez tendo-se decidido trabalhar em um trecho limitado da linha $F$, da estação Comendador Ermelino à Itaim Paulista, as seis cenas inicialmente necessárias reduziram-se à quatro, discriminadas no Quadro 6. 
FOTO-ÍNDICE

MOSAICO DE ORTO-IMAGENS DA REGIÃO METROPOLITANA DE SÃO PAULO

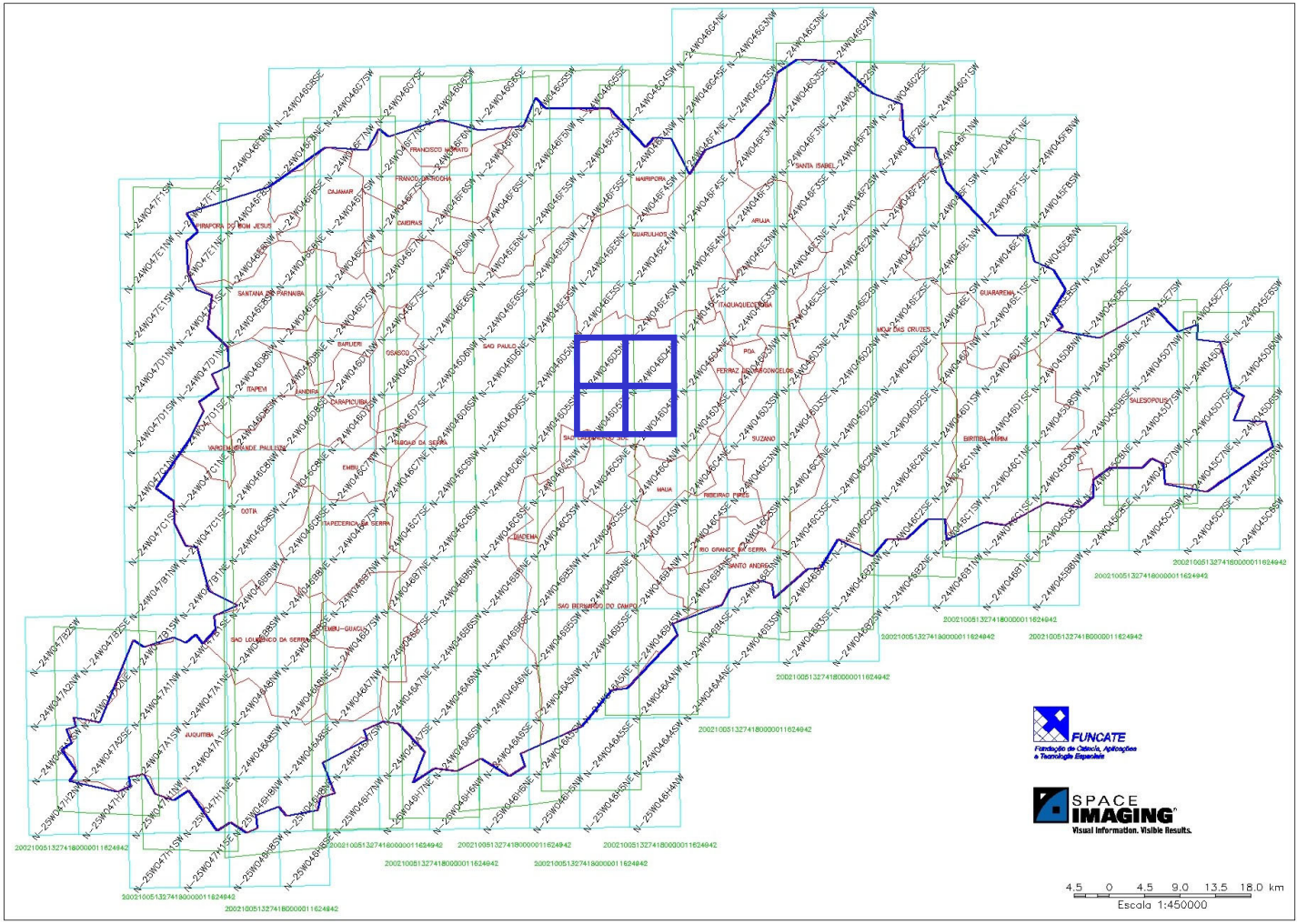

Figura 24 - Estrutura das folhas da coleção de imagens e as respectivas informações de órbita e data de captura das imagens IKONOS II. Em destaque, as folhas cujas imagens foram utilizadas nesse projeto.

Fonte: FUNCATE (2004).

Quadro 6 - Discriminação das cenas utilizadas no projeto.

\begin{tabular}{|l|l|}
\hline N24W046D4SW.blu & N24W046E4SE.blu \\
N24W046D4SW.grn & N24W046E4SE.grn \\
N24W046D4SW.red & N24W046E4SE.red \\
N24W046D4SW.nir & N24W046E4SE.nir \\
\hline N24W046D4NW.blu & N24W046D4NE.blu \\
N24W046D4NW.grn & N24W046D4NE.grn \\
N24W046D4NW.red & N24W046D4NE.red \\
N24W046D4NW.nir & N24W046D4NE.nir \\
\hline
\end{tabular}


Para obtenção de uma única imagem que cobrisse a área de interesse, as quatro cenas foram então importadas para o software ENVI 4.2, cada qual com suas quatro bandas. Com base no geo-referenciamento das cenas, as mesmas foram justapostas formando-se uma única cena. $\mathrm{Na}$ seqüência, as quatro cenas foram balanceadas, tendo como referência a cena N24W046D4SW. Esta foi escolhida por conter maior variedade de elementos. Ambos os procedimentos podem ser visualizados na Figura 25.

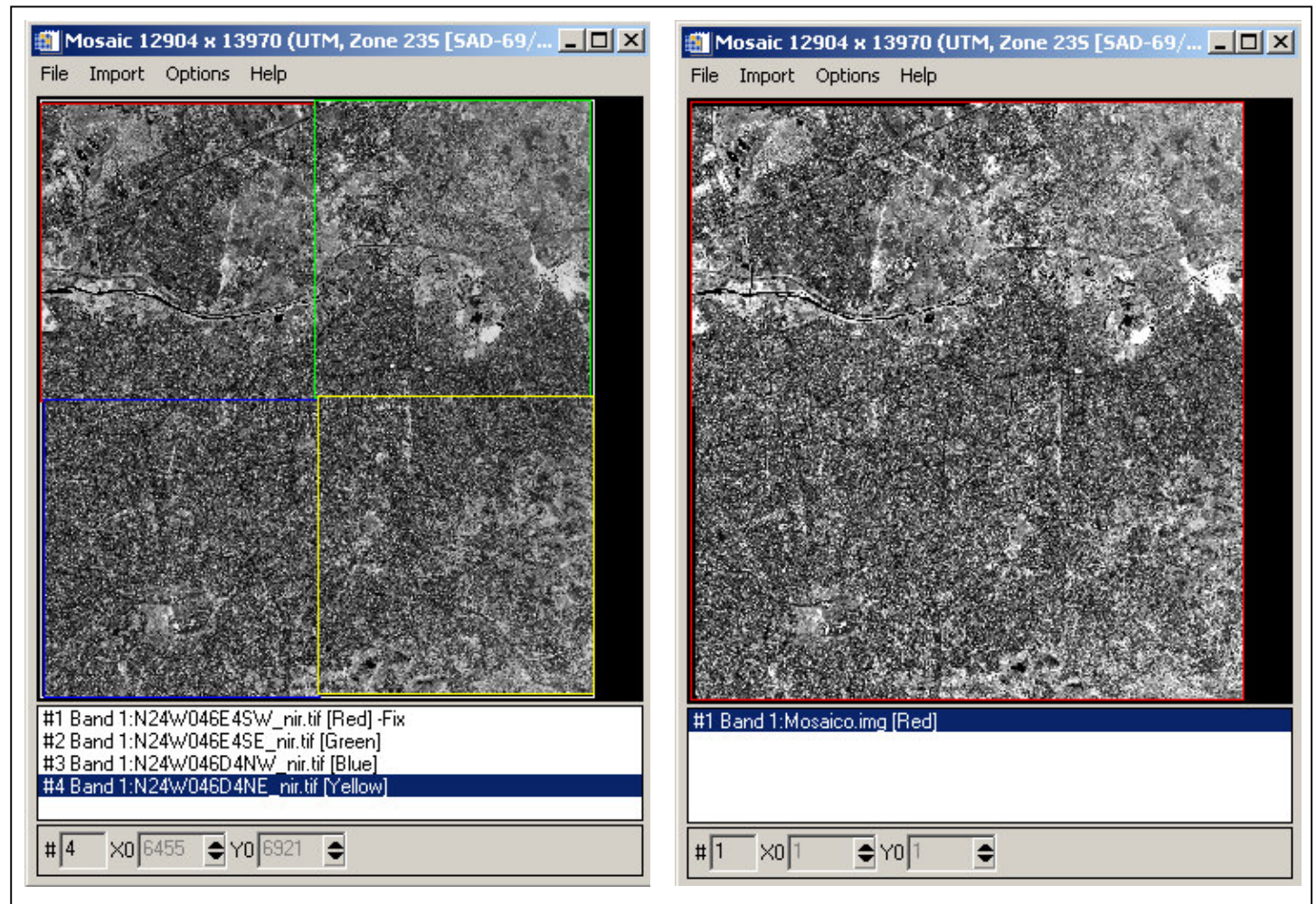

Figura 25 - À esquerda composição do mosaico com as quatro cenas necessárias para cobertura parcial da Linha F, à direita as cenas já mosaicadas e balanceadas.

\subsection{Definição de área de estudo}

Embora as cenas mosaicadas tenham sido necessárias para compor toda a área de interesse, a imagem final obtida apresentou tamanho consideravelmente grande, tornando seu processamento digital inviável. Partindo-se do objetivo de identificar a cobertura do solo no entorno da linha, 
não houve necessidade de se manter a imagem na íntegra, como pode ser visto na Figura 26.

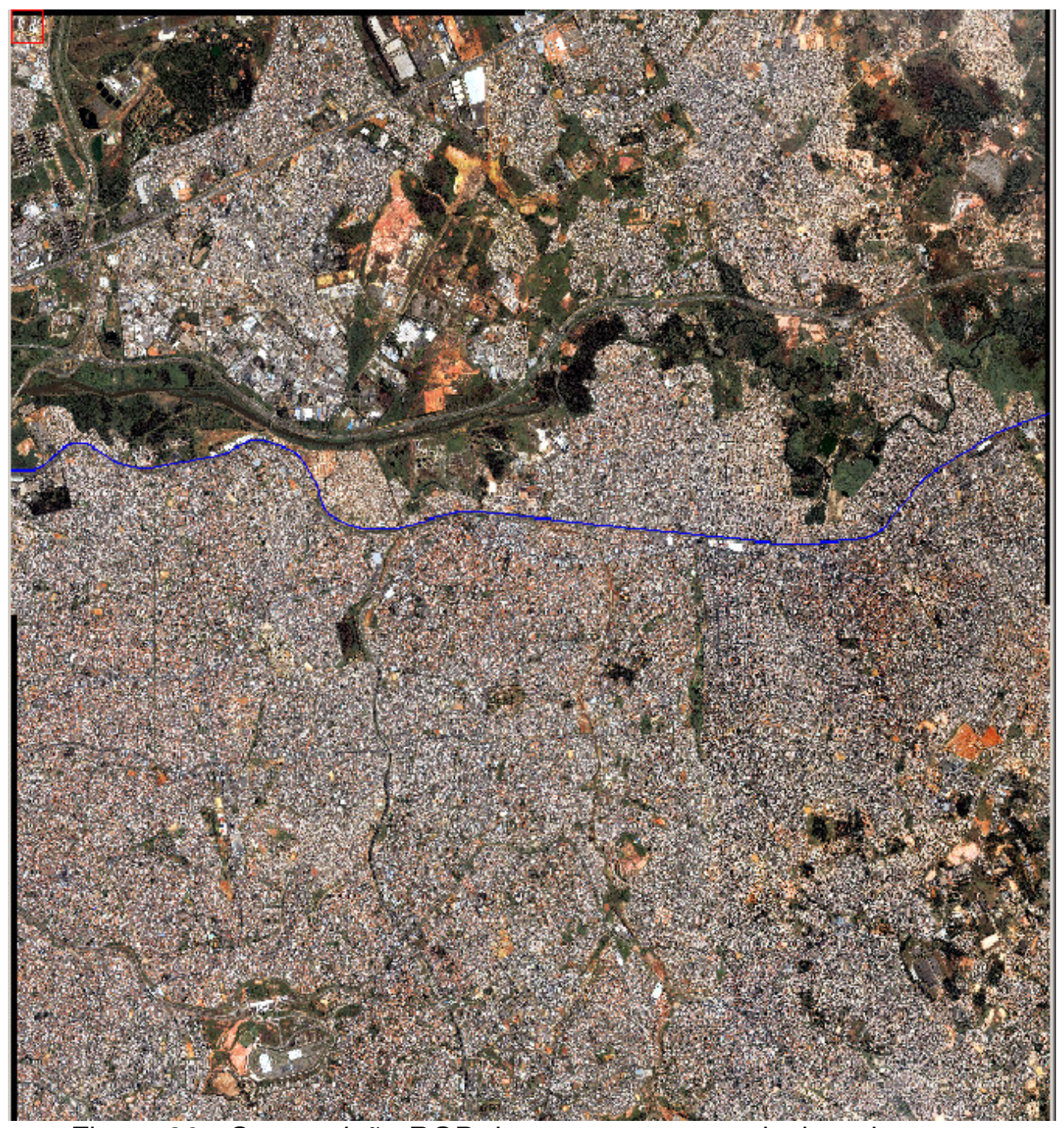

Figura 26 - Composição RGB das quatro cenas selecionadas com a sobreposição de um trecho da Linha F.

Desta forma, delimitou-se uma área de $750 \mathrm{~m}$ ao redor da linha, passando a ser o objeto de estudo. Para se definir a esta distância, considerou-se a melhor combinação possível ente uma área caparz de incluir todos os elementos visualmente identificados na cena e o tamanho final da imagem tratável para fins de processamento digital. A delimitação da 
área final de estudo foi gerada utilizando-se o programa Spring 4.2, podendo ser visualizada na Figura 27.

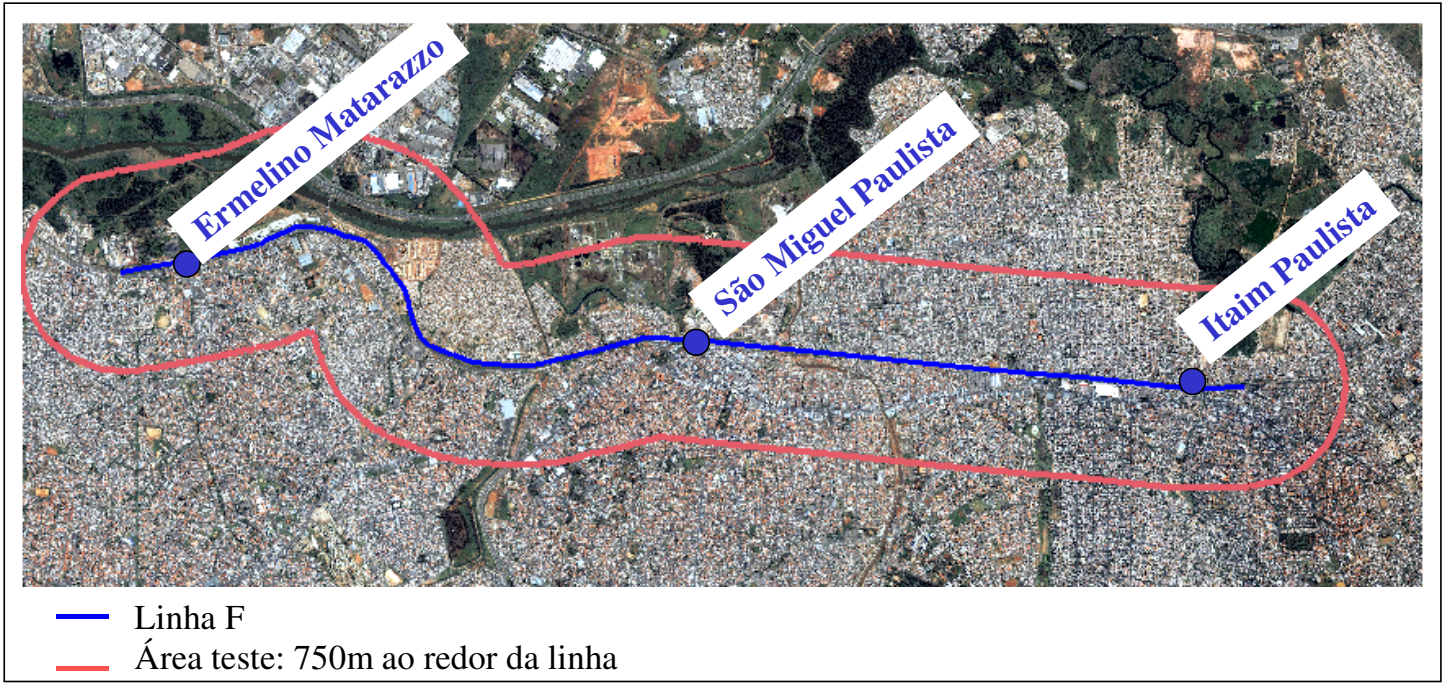

Figura 27 - Delimitação da área de teste, compreendendo 750m ao redor da linha de trem.

\subsection{Processamento digital}

Uma vez definida a área do projeto, deu-se início ao processamento digital da imagem propriamente dito, com intuito de se identificar e classificar os objetos presentes na imagem, de acordo com suas características.

\subsubsection{Definição das classes de objetos}

A definição das classes de objetos foi feita com base no sistema CORINE, a partir do nível III, classe 1.2.2, correspondendo a estradas, ferrovias e faixas de servidão. Como os níveis subseqüentes encontram-se em aberto, o presente trabalho propôs classes para o nível IV, com base no conhecimento do analista.

Desta forma, a análise visual da imagem permitiu identificar objetos e materiais com maior representatividade na cena, além de suas características, como cor, forma e textura, gerando uma chave classificatória 


\section{para o nível IV. O Quadro 7 apresenta as classes de objetos identificados}

com algumas de suas características.

\section{Quadro 7 - Classes identificadas na imagem com algumas de suas características.}

\begin{tabular}{|c|c|c|c|c|c|}
\hline Classe & Visualização & Cor em RGB & Cor em CIR & Localização & Características \\
\hline $\begin{array}{l}\text { Vegetação } \\
\text { densa }\end{array}$ & & $\begin{array}{ll}\text { Variando } & \text { de } \\
\text { verde escuro ao } \\
\text { médio. }\end{array}$ & $\begin{array}{ll}\text { Variando } & \text { do } \\
\text { vermelho } & \\
\text { escuro } & \text { ao } \\
\text { vivo. } & \end{array}$ & \begin{tabular}{|lr} 
Quanto & em \\
tonalidades & \\
mais escuras, é \\
ladeada r por \\
sombras & e \\
outras & de \\
tonalidades & \\
mais vivas. & \\
\end{tabular} & $\begin{array}{l}\text { Textura } \\
\text { variando de forma de } \\
\text { acordo com } \\
\text { agrupamento. }\end{array}$ \\
\hline $\begin{array}{l}\text { Vegetação } \\
\text { rasteira }\end{array}$ & & $\begin{array}{l}\text { Predomínio do } \\
\text { verde médio a } \\
\text { claro. }\end{array}$ & $\begin{array}{l}\text { Predomínio do } \\
\text { vermelho vivo. }\end{array}$ & \begin{tabular}{lr}
\multicolumn{2}{|l}{ Ladeando } \\
vegetação mais \\
densa, também \\
presente & ao \\
longo de & eixos \\
viários & e \\
cercada & de \\
coberturas & de \\
diversos & \\
materiais. & \\
\end{tabular} & $\begin{array}{l}\text { Textura levemente } \\
\text { rugosa. Forma variada, } \\
\text { com predomínio da } \\
\text { retangular. }\end{array}$ \\
\hline Água & & $\begin{array}{l}\text { Variando de } \\
\text { marrom escuro } \\
\text { à cinza escuro. }\end{array}$ & Cinza escuro. & $\begin{array}{lr}\text { Ladeada } & \text { por } \\
\text { vegetação } & \\
\text { (densa } & \text { e } \\
\text { rasteira), rolo } \\
\text { exposto } & \text { escuro } \\
\text { e asfalto. } & \end{array}$ & $\begin{array}{l}\text { Textura lisa. Forma } \\
\text { linear e curvilínea. }\end{array}$ \\
\hline $\begin{array}{l}\text { Solo } \\
\text { exposto } \\
\text { claro }\end{array}$ & & $\begin{array}{l}\text { Variando de } \\
\text { bege a amarelo } \\
\text { bem claro. }\end{array}$ & $\begin{array}{l}\text { Tonalidades } \\
\text { de verde claro }\end{array}$ & $\begin{array}{lr}\text { Ladeada } & \text { por } \\
\text { vegetação } & \\
\text { rasteira, } & \\
\text { amianto, } & \text { asfalto } \\
\text { e } & \text { outras } \\
\text { variações } & \text { de } \\
\text { solo. } & \end{array}$ & $\begin{array}{l}\text { Textura lisa. Forma } \\
\text { apresenta variações, } \\
\text { com predomínio da } \\
\text { retangular. }\end{array}$ \\
\hline $\begin{array}{l}\text { Solo } \\
\text { exposto } \\
\text { médio }\end{array}$ & & $\begin{array}{l}\text { Avermelhada, } \\
\text { semelhante à } \\
\text { ferrugem. }\end{array}$ & $\begin{array}{l}\text { Variações de } \\
\text { verde } \\
\text { amarelado. }\end{array}$ & $\begin{array}{lr}\text { Ladeada } & \text { por } \\
\text { vegetação } & \\
\text { rasteira, } & \\
\text { cobertura } & \\
\text { metálica } & \text { e } \\
\text { amianto. } & \end{array}$ & $\begin{array}{l}\text { Textura variável, com } \\
\text { predomínio da lisa. } \\
\text { Forma apresenta } \\
\text { variações, r com } \\
\text { predomínio da linear. }\end{array}$ \\
\hline $\begin{array}{l}\text { Solo } \\
\text { exposto } \\
\text { escuro }\end{array}$ & & $\begin{array}{l}\text { Variando de } \\
\text { marrom médio a } \\
\text { cinza escuro. }\end{array}$ & $\begin{array}{l}\text { Tons escuros } \\
\text { de vermelho } \\
\text { acinzentado. }\end{array}$ & $\begin{array}{l}\text { Geralmente } \\
\text { acompanhada } \\
\text { de solo exposto } \\
\text { claro } \\
\text { vegetação } \\
\text { rasteira. }\end{array}$ & $\begin{array}{l}\text { Textura rugosa média. } \\
\text { Sem formato definido. }\end{array}$ \\
\hline
\end{tabular}




\begin{tabular}{|c|c|c|c|c|c|}
\hline Classe & Visualização & Cor em RGB & Cor em CIR & Localização & Características \\
\hline $\begin{array}{l}\text { Cobertura } \\
\text { metálica }\end{array}$ & & $\begin{array}{l}\text { Variações } \\
\text { azul claro. }\end{array}$ & $\begin{array}{l}\text { Variações de } \\
\text { azul médio } \\
\text { acinzentado. }\end{array}$ & $\begin{array}{lr}\text { Ladeado } & \text { por } \\
\text { sombra } & \mathrm{e} \\
\text { próximo } & \text { aos } \\
\text { principais } & \text { eixos } \\
\text { viários. } & \end{array}$ & $\begin{array}{lr}\text { Textura } & \text { variando de } \\
\text { lisa a levemente } \\
\text { rugosa. } & \text { Forma } \\
\text { retangular de tamanhos } \\
\text { variados. }\end{array}$ \\
\hline $\begin{array}{l}\text { Concreto ou } \\
\text { amianto } \\
\text { claro }\end{array}$ & & $\begin{array}{l}\text { Branca, } \\
\text { tonalidade } \\
\text { levemente } \\
\text { azulada. }\end{array}$ & Cyan. & $\begin{array}{ll}\text { Ladeada } & \text { por } \\
\text { sombra } & \text { e, em } \\
\text { muitos } & \text { casos, } \\
\text { por } & \text { outras } \\
\text { variações } & \text { de } \\
\text { amianto. } & \end{array}$ & $\begin{array}{l}\text { Textura lisa. Forma } \\
\text { predominantemente } \\
\text { retangular e tamanhos } \\
\text { variados. }\end{array}$ \\
\hline $\begin{array}{l}\text { Concreto ou } \\
\text { amianto } \\
\text { escuro }\end{array}$ & & $\begin{array}{l}\text { Cinza médio a } \\
\text { escuro. }\end{array}$ & Cinza escuro & $\begin{array}{lr}\text { Ladeado } & \text { por } \\
\text { sombra, asfalto } \\
\text { e } & \text { outras } \\
\text { variações } & \text { de } \\
\text { amianto. } & \end{array}$ & $\begin{array}{l}\text { Textura rugosa. Forma } \\
\text { predominantemente } \\
\text { retangular e tamanhos } \\
\text { variados. }\end{array}$ \\
\hline $\begin{array}{l}\text { Telha } \\
\text { cerâmica }\end{array}$ & & $\begin{array}{c}\text { Variando de } \\
\text { laranja médio a } \\
\text { claro. }\end{array}$ & $\begin{array}{l}\text { Variações de } \\
\text { laranja } \\
\text { amarelado. }\end{array}$ & $\begin{array}{l}\text { Ladeado por } \\
\text { sombra, outras } \\
\text { variações de } \\
\text { cobertura e } \\
\text { proximidade } \\
\text { com asfalto. }\end{array}$ & $\begin{array}{c}\text { Textura rugosa. Forma } \\
\text { predominantemente } \\
\text { retangular e tamanhos } \\
\text { variados }\end{array}$ \\
\hline Asfalto & & $\begin{array}{c}\text { Cinza médio a } \\
\text { escuro. }\end{array}$ & $\begin{array}{l}\text { Cinza azulado } \\
\text { de médio a } \\
\text { escuro. }\end{array}$ & $\begin{array}{c}\text { Proximidade } \\
\text { com diversas } \\
\text { variações de } \\
\text { cobertura. }\end{array}$ & $\begin{array}{l}\text { Formas alongada } \\
\text { (eixos viários) e } \\
\text { retangular e quadrada } \\
\text { (estacionamentos). }\end{array}$ \\
\hline Sombra & & Preto. & Preto. & 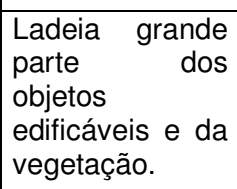 & $\begin{array}{l}\text { Textura lisa. Forma e } \\
\text { tamanho variáveis, de } \\
\text { acordo com o objeto } \\
\text { que a produz. }\end{array}$ \\
\hline
\end{tabular}

\subsubsection{Segmentação}

A segmentação foi realizada com objetivo de delinear objetos, através do agrupamento de pixels com base em suas propriedades radiométricas. Para tanto, usou-se a segmentação por crescimento de regiões, agrupando os pixels em regiões, anexando a cada pixel inicial outros pixels que apresentaram propriedades similares, como nível de cinza, textura e cor. 
Para tal processamento, o software Spring 4.2 necessita que se estabeleçam previamente valores de similaridade e área, onde o primeiro corresponde ao limite de variação da propriedade radiométrica e o segundo ao tamanho mínimo da área em pixels. Desta forma, alguns testes foram realizados em busca de uma combinação de valores capaz de delinear feições urbanas, como telhados e vias, tendo-se chegado à combinação de valores 30 de similaridade e 50 de área, cujo resultado permitiu o delineamento desejado dentro da proposta de trabalho. A Figura 28 ilustra, uma área com sua respectiva segmentação. 


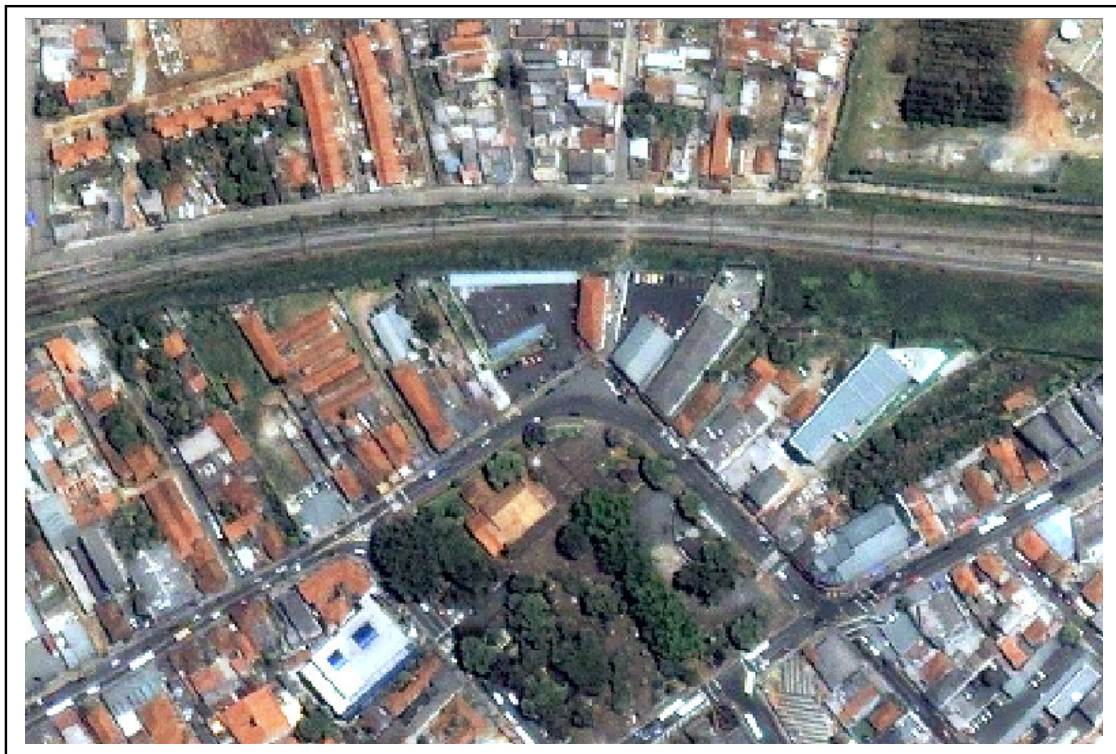

1 (a)

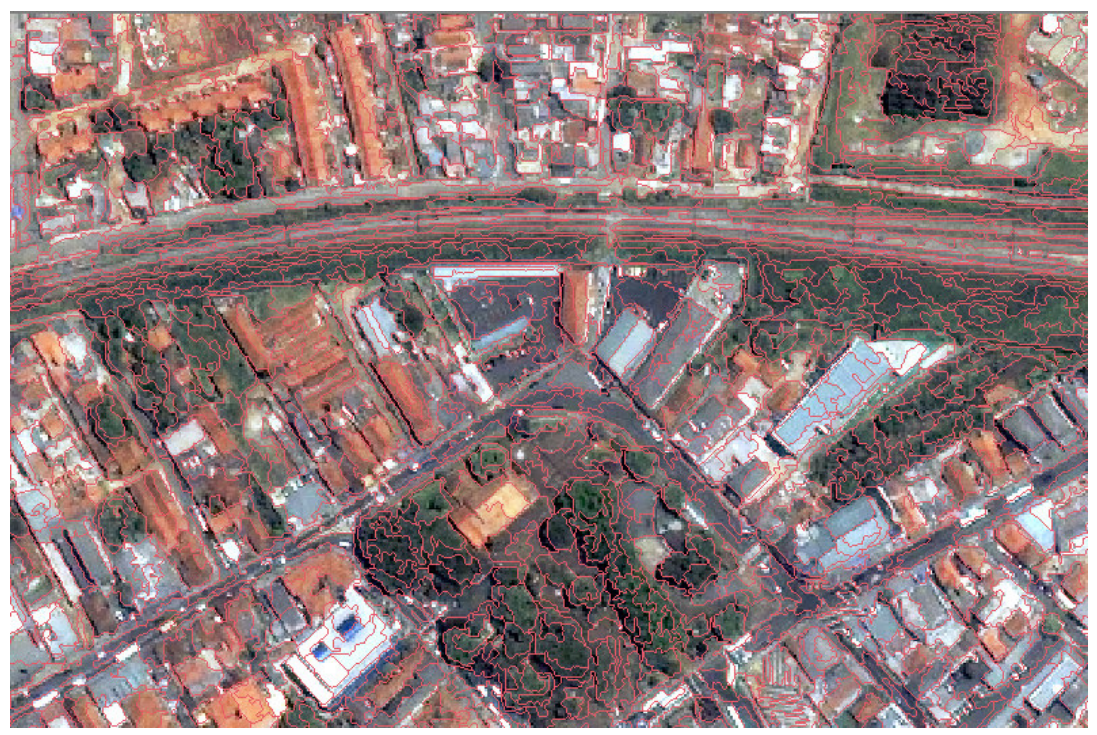

1 (b)

Figura 28 - 1(a) Detalhe da área de trabalho e 1(b) a mesma área com a segmentação das feições.

\subsubsection{Classificação da imagem}


A imagem foi classificada em regiões, que por sua vez, correspondem aos polígonos gerados na etapa da segmentação. A classificação foi realizada usando-se o algoritmo Bhattacharyya, disponível no Spring 4.2, tendo como contexto as quatro bandas da imagem.

Esta classificação é supervisionada, requerendo amostras de segmentos, e não de pixels isolados, como os demais classificadores baseados em pixels. Desta forma, amostras de segmentos representativos das 12 classes foram selecionadas.

\subsubsection{Pós-Classificação}

O objetivo desta fase foi a identificação e aplicação de critérios, ou regras, sobre a imagem já classificada, de forma a corrigir possíveis erros cometidos na etapa anterior.

Numa primeira fase do processo fez-se a avaliação da classificação gerada na etapa anterior, comparando-se os polígonos classificados com os de referência. Os polígonos classificados corretamente serviram de base para caracterização das classes. A opção pelo uso de polígonos classificados ao invés dos segmentos originais para caracterização das classes, deveu-se ao fato de, ao ser convertida de matriz para vetor, a imagem classificada não manteve todos os segmentos originais, mas agregou segmentos vizinhos atribuídos a mesma classe. A manutenção do formato matriz resguardaria a segmentação original, mas perder-se-ia atributos de referência, como área e perímetro.

Os polígonos classificados corretamente foram analisados tanto com base em seus atributos, como área e perímetro, como também em seu contexto na cena. Critérios de reclassificação também foram gerados a partir das relações topológicas dos polígonos da imagem classificada, com os das bases digitais de quadras e logradouros e também com geração de imagem NDVI.

A sobreposição das bases de quadras e logradouros demandou um ajuste das mesmas sobre a imagem. $O$ presente trabalho absteve-se de 
realizar a correção geométrica entre os modelos de dados envolvidos, limitando-se apenas a um ajuste simples. Fez-se essa opção com intuito de preservar os dados originais da imagem, bem como a segmentação e classificação já realizadas, uma vez que os vetores de quadras e logradouros foram utilizados apenas em consultas de relações espaciais, não demandando maior grau de precisão. As Figuras 29 e 30 ilustram a sobreposição antes e depois do ajuste, respectivamente.

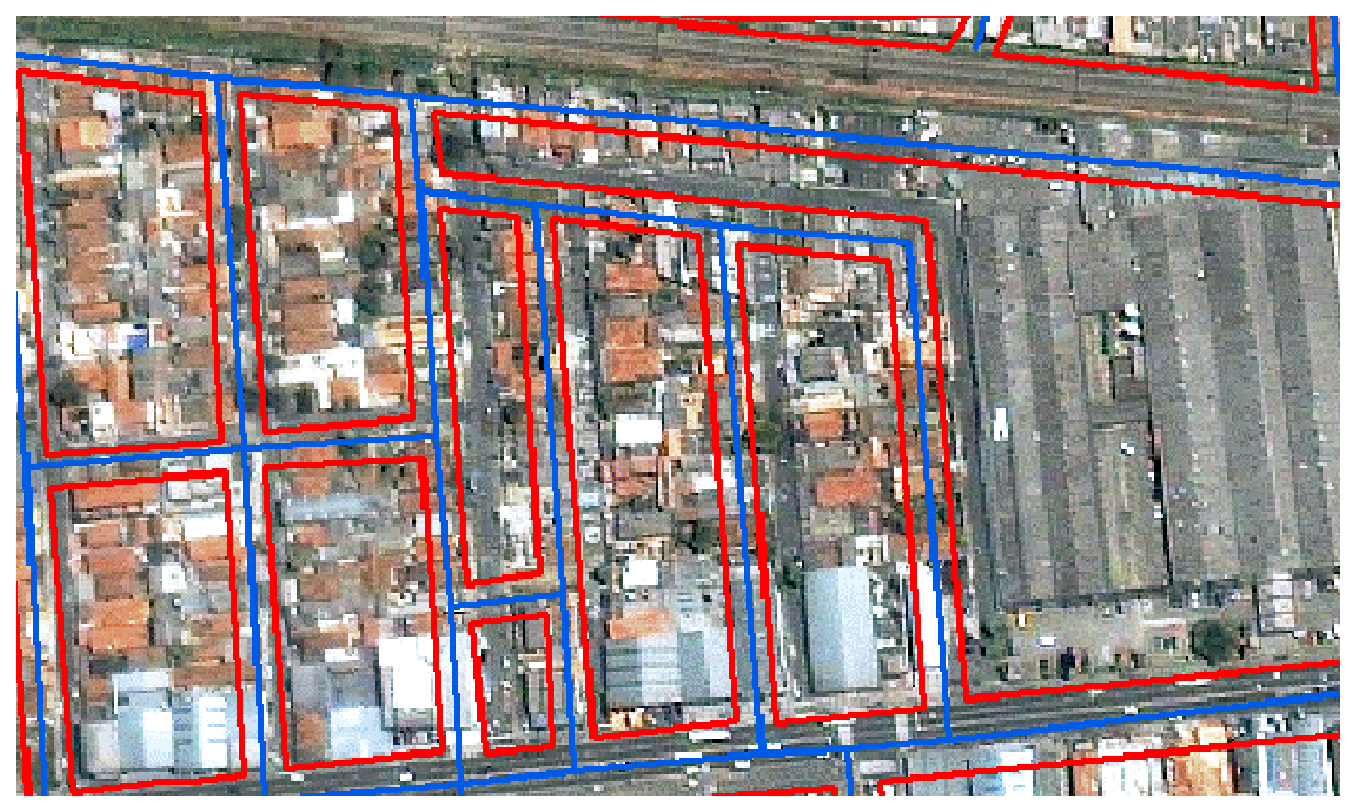

Figura 29. Sobreposição dos vetores de quadras (vermelho) e logradouros (azul) em relação à imagem antes do ajuste. 


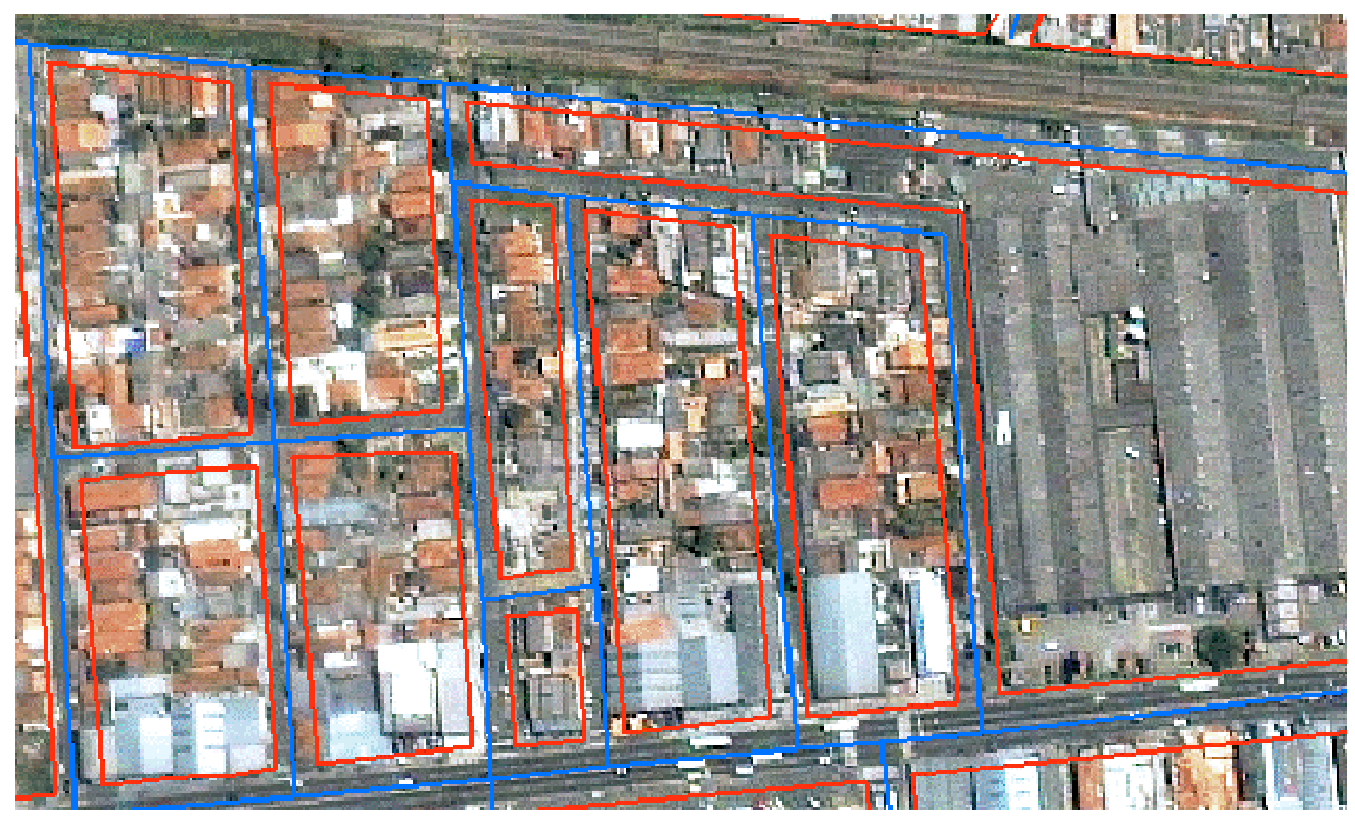

Figura 30. Sobreposição dos vetores de quadras (vermelho) e logradouros (azul) em relação à imagem após o ajuste.

Para auxiliar na reclassificação das classes vegetação rasteira e vegetação densa, gerou-se uma imagem NDVI. A imagem resultante teve seus valores (0 a 99) escalonados em três níveis, procurando relacioná-los às classes já determinadas, conforme segue:

- 0 a 18: ausência de vegetação, ou áreas impermeáveis;

- 18,1 a 53: vegetação rasteira;

- 53,1 a 99: vegetação densa.

Chegou-se a estes cortes de valores comparando-se a imagem NDVI com a imagem classificada. A Figura 31 ilustra a imagem NDVI sobre um recorte da área de estudo. 

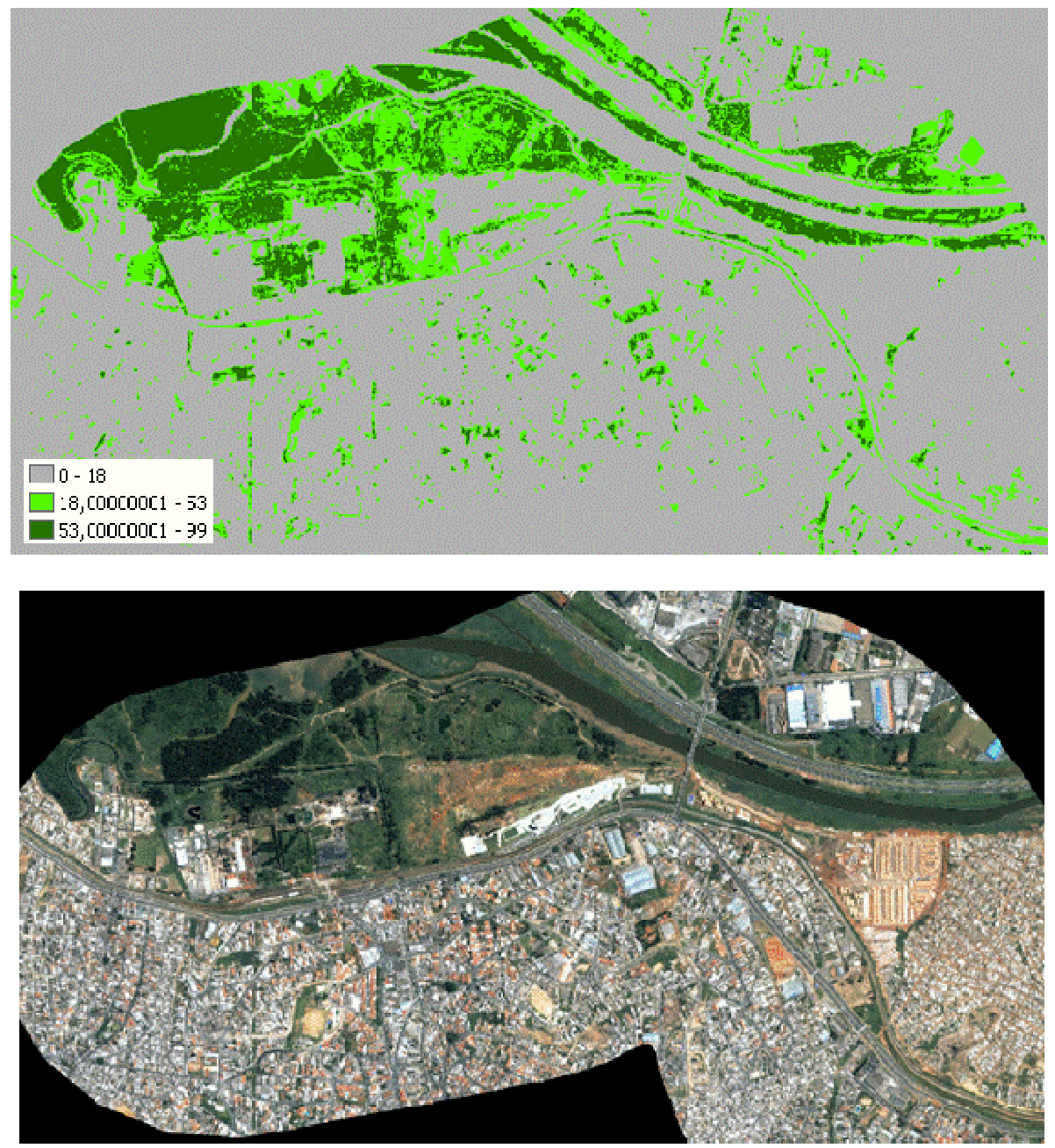

Figura 31. Acima, exemplo do NDVI gerado e abaixo a mesma área com a imagem original correspondente.

Uma vez criados critérios para as doze classes (vegetação densa, vegetação rasteira, água, sombra, amianto claro, amianto escuro, cobertura metálica, asfalto, solo exposto claro, solo exposto médio, solo exposto escuro e telha cerâmica), os polígonos foram avaliados. Os que originalmente já pertenciam à classe tiveram seus registros inalterados, mas os que haviam sido classificados erroneamente foram reclassificados.

\subsection{Avaliação da Classificação}


Os polígonos de referência não tiveram a veracidade de suas respectivas classes verificada diretamente em campo, mas foram obtidas através da interpretação visual da imagem IKONOS II utilizada no projeto. A ausência de uma visita a campo se justifica principalmente pelo considerável intervalo de tempo decorrido entre a geração da imagem IKONOS II (2002) com um possível levantamento de campo atual. Uma das vantagens de amostras reais em campo é a obtenção de dados fidedignos, o que poderia não ocorrer neste caso, considerando-se a dinâmica da paisagem urbana provocada não apenas pela mudança nos padrões de ocupação do solo, como também pela degradação dos materiais, principalmente em regiões periféricas.

Selecionou-se dentro do projeto, uma área teste contínua na qual estivessem representadas todas as classes de interesse. A opção de se trabalhar com polígonos contínuos de referência ao invés das amostragens discretas tradicionais foi feita visando manter as relações topológicas e contextuais para um futuro aproveitamento na criação dos critérios de reclassificação.

A área teste selecionada corresponde a $698.803 \mathrm{~m}^{2}$ divididos em 1.561 polígonos e seu contexto na área total do projeto pode ser visualizada na Figura 32. 


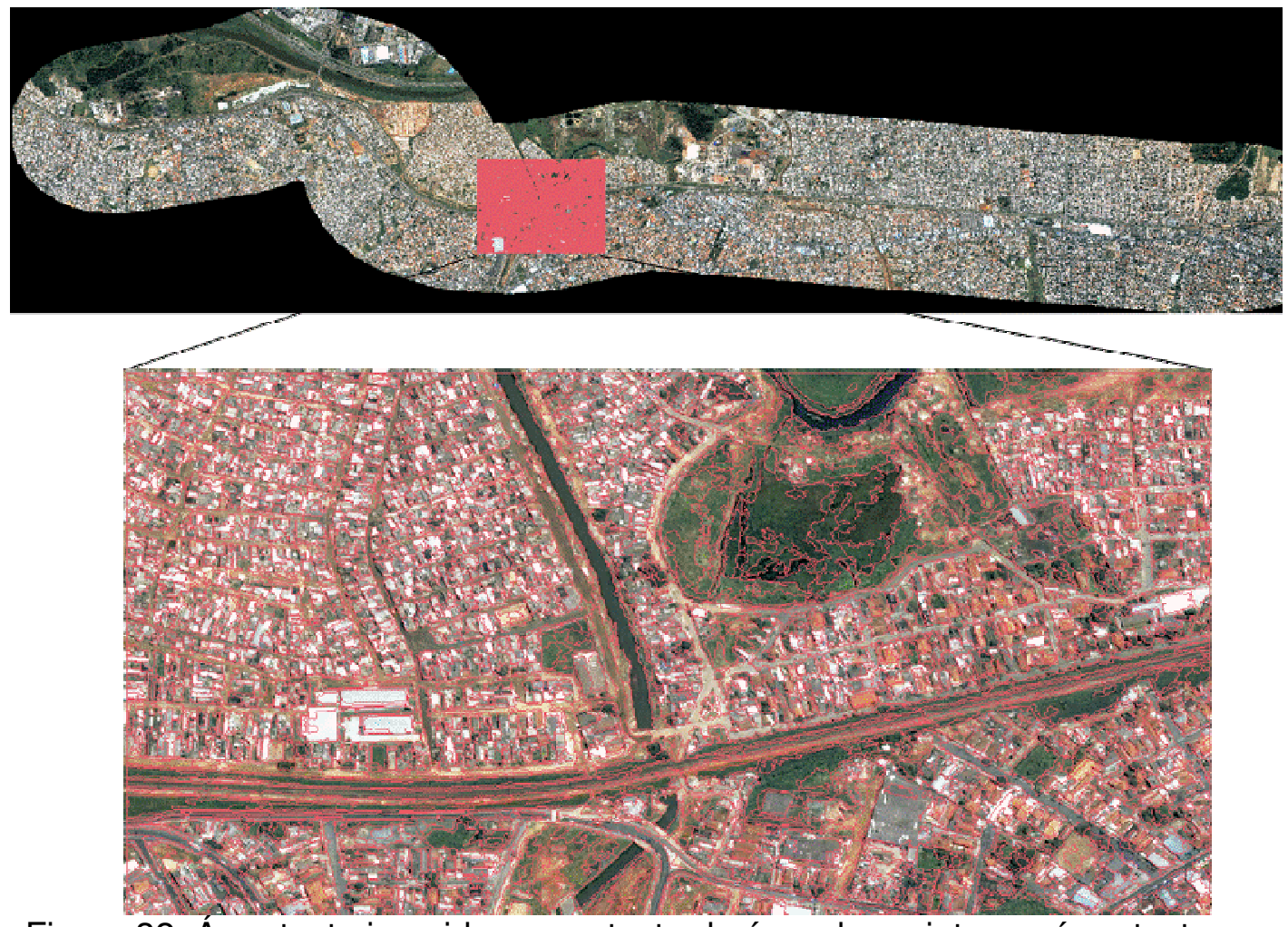

Figura 32. Área teste inserida no contexto da área do projeto e a área teste em detalhe com vetor de segmentação sobreposto abaixo.

Tradicionalmente a área total das classes é obtida pela somatória dos pixels correspondentes na imagem. Neste trabalho, contudo, como as análises foram desenvolvidas sobre dados vetoriais, a contagem de pixels foi substituída pelo somatório das áreas dos polígonos, sendo $0 \mathrm{~m}^{2}$ sua unidade de medida.

\subsection{1 Índices de avaliação}

A avaliação do desempenho de uma classificação de imagem é geralmente obtida a partir da matriz de classificação, também conhecida por matriz de confusão ou matriz de erro, que fornece a distribuição das unidades classificadas correta e erroneamente. A matriz de confusão compara, classe a classe, a relação entre dados de referência - tidos como verdade de campo - e os dados resultantes de uma classificação 
automática. A matriz é quadrada, com igual número de linhas e colunas, correspondendo à cada classe identificada na classificação (LILLESAND et al., 2004).

A matriz de confusão fornece informações gerais sobre o desempenho da classificação, como erros de omissão - quando um elemento é excluído da classe à qual pertence - e erros de comissão quando um elemento é incluído numa classe à qual não pertence.

Outras medidas descritivas podem ser extraídas a partir da matriz de confusão, como exatidão global, exatidão do usuário e exatidão do produtor (LILLESAND et al., 2004), e atuam como parâmetros complementares para atestar a eficiência e a deficiência da classificação (NÓBREGA, 2007). A Figura 33 exemplifica uma matriz de confusão.

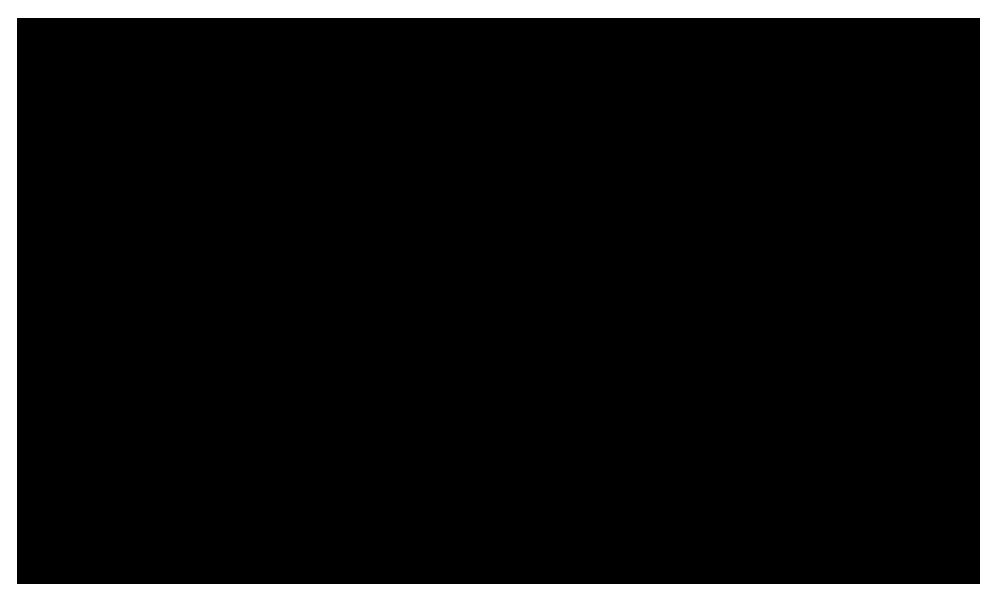

Figura 33. Típica matriz de confusão.

Fonte: Adaptado de Skidmore, 1999.

A exatidão global (eg) é calculada dividindo-se o número total de elementos classificados corretamente, alocados na diagonal maior da matriz, pelo total de elementos de referência, cuja fórmula é apresentada na equação 2, refletindo o desempenho geral da classificação (LILLESAND et al., 2004). 
$e g=\frac{\sum x_{i i}}{N}$

onde:

$X_{i i}=$ elementos da diagonal principal

$N$ = somatório dos elementos de referência

A exatidão do usuário (eu) representa os erros de comissão da classificação, indicando a probabilidade de um elemento classificado numa determinada categoria realmente pertencer a ela, sendo calculada pela equação 3 (LILLESAND et al., 2004).

$e u=\frac{x_{i i}}{x_{i+}}$

Onde:

$x_{i i}=$ elementos classificados corretamente numa determinada classe

$x_{i+}=$ elementos classificados numa determinada classe

A exatidão do produtor (ep) é corresponde aos erros de omissão da classificação, calculada dividindo-se o número de elementos classificados corretamente numa determinada classe pelo número de elementos de referência desta mesma categoria, conforme equação 4 (LILLESAND et al., 2004).

$e p=\frac{x_{i i}}{x_{+i}}$

onde:

$x_{i i}=$ número de elementos classificados corretamente numa dada classe

$x_{+i}=$ número de elementos de referência para uma dada classe

Um dos indicadores mais comumente usados para avaliação da classificação de imagens de sensoriamento remoto é o índice Kappa, consistindo na medida da diferença de concordância dos dados de 
referência e a classificação automática e a probabilidade de concordância entre os dados de referência e a classificação aleatória, sendo estatisticamente expresso da seguinte forma (LILLESAND et al.; 2004; IWAI e QUINTANILHA, 2005):

$$
k=\frac{N \sum_{i=1}^{n} x_{i i}-\sum x_{i+} x_{+i}}{N^{2}-\sum_{i=1}^{n} x_{i+} x_{+i}}
$$

onde:

$x_{i i}=$ concordância observada

$x_{+i}$ e $x_{i+}=$ produtos marginais, correspondendo a concordância esperada

$N=$ número total de células

$\mathrm{n}=$ número de linhas no quadro de classificação

O coeficiente $k$ apresenta como resultado valores numa escala de 0 a 1 , onde zero significa total desacordo, enquanto um valor igual a 1 indica total concordância entre o resultado da classificação e os dados de referência (MATHER, 2005). 


\section{RESULTADOS E DISCUSSÕES}

Este capítulo apresenta os resultados obtidos em cada uma das fases de processamento da imagem e avaliação da classificação descritas na metodologia, acrescidos de considerações relativas à sua execução.

\subsection{Segmentação}

A técnica da segmentação dividiu a imagem em regiões correspondentes aos objetos de interesse. Para tanto, diversas combinações de valores foram testadas para os critérios de similaridade e área, especialmente este último, em virtude de ser o mais importante para classificação por regiões.

Para similaridade, procurou-se um valor mediano que permitisse tanto a identificação dos diversos materiais identificados na cena - o que seria relativamente simples utilizando valores baixos - mas não tão restrito a ponto de separar nuances na refletividade de um mesmo elemento, como, por exemplo, separar os lados direito e esquerdo de um telhado cerâmico. O valor adotado foi 30, permanecendo este inalterado para os testes de área.

Para área, os testes iniciaram-se com valores baixos, procurando identificar a viabilidade de se trabalhar com objetos de baixa dimensão. Porém, a grande limitação ocorreu em termos computacionais, não tendo sido possível finalizar nenhum dos processamentos de segmentação onde adotou-se valores de área inferior a 50 pixels.

A combinação 30-50 resultou numa segmentação consideravelmente detalhada, eficiente na delimitação dos objetos de menores dimensões da cena, mas não tão eficiente em se tratando de elementos de maior dimensão, como parques e rios, por representá-los em número de segmentos muito superior ao que seria necessário. A Figura 34 ilustra essa situação. 

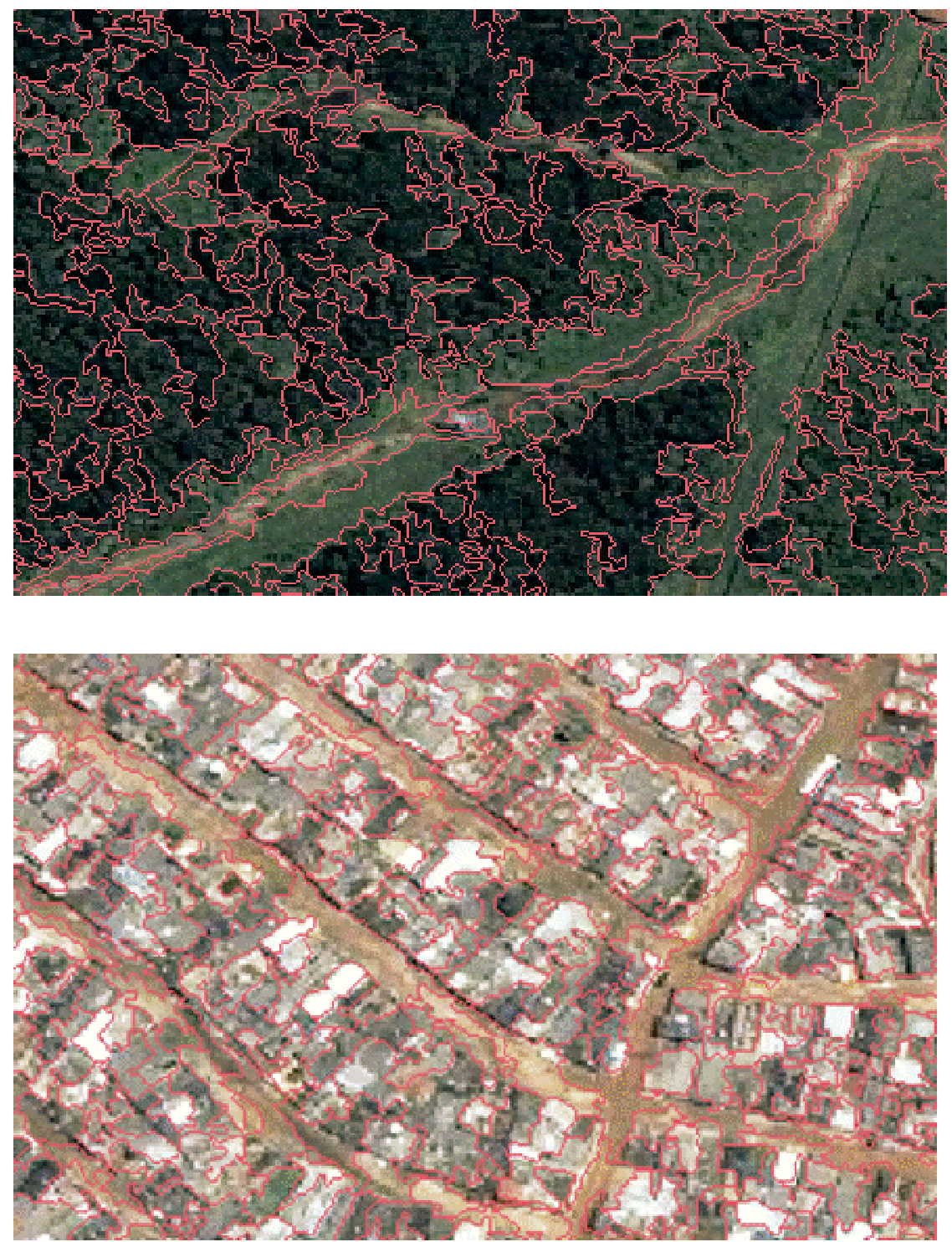

Figura 34. Acima, extensa área de vegetação e elevado número de segmentos; abaixo, área de construção irregular e de baixa dimensão, mas bem delimitada.

A Figura 36 permite observar também que o nível de detalhamento obtido com os parâmetros adotados - 30 e 50 - possibilitou uma reduzida confusão entre as classes, mas foi elevado demais para manter a forma dos elementos. Considerando-se que a forma dos objetos não foi utilizada como critério de classificação, por impossibilidade do software utilizado, optou-se por manter esses valores. 


\subsection{Classificação por regiões}

Uma primeira análise visual da classificação permite afirmar que o resultado foi satisfatório, podendo ser visualizado na Figura 35. 


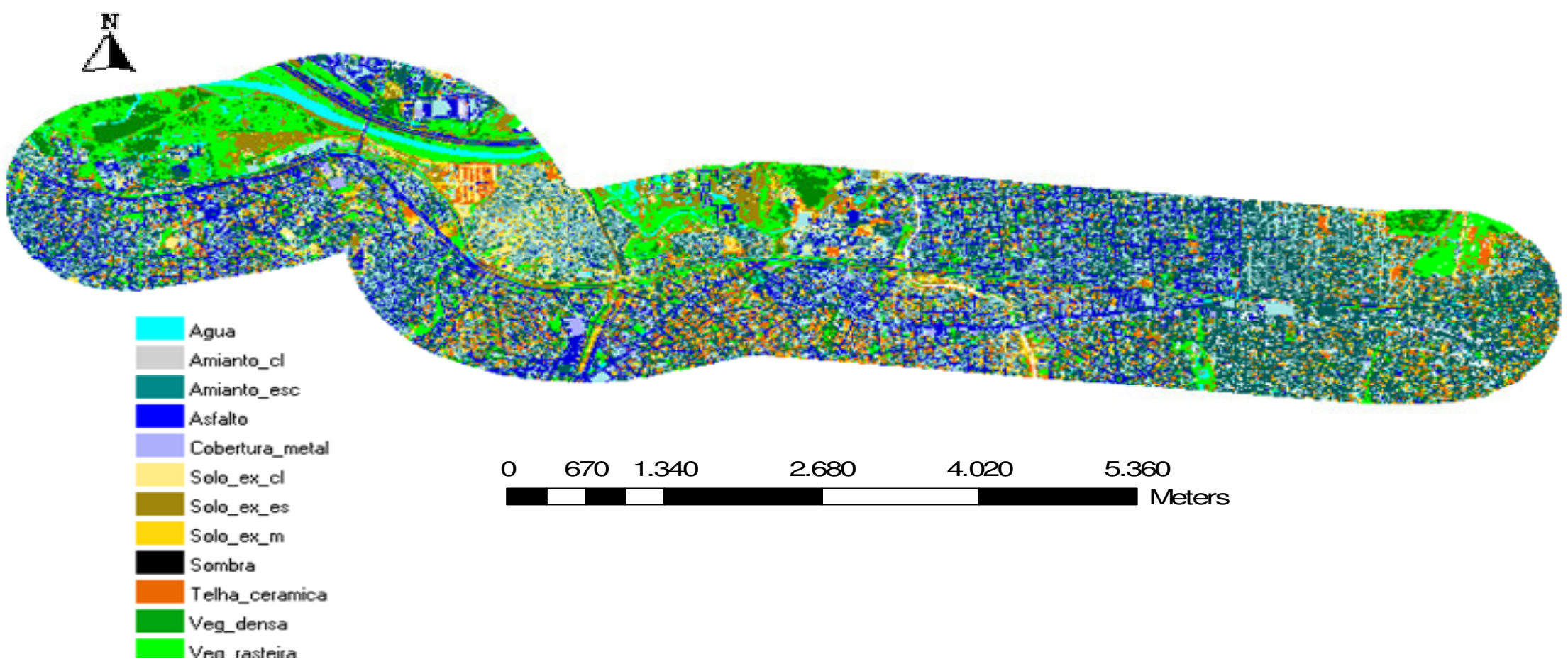

Figura 35. Resultado da classificação por regiões na área de estudo. 
Comparando-se visualmente a imagem com a classificação, percebese uma confusão entre algumas classes, como solo exposto médio e telhado cerâmico, asfalto com concreto médio e escuro e água e sombra. Esta confusão já era esperada devido à semelhança do comportamento espectral verificada entre os elementos constituintes destas classes (SOUZA e KUX, 2005). A Figura 36 representa uma área em que a confusão pode ser verificada.

Asfalto classificado como amianto Telhado cerâmico classificado como solo
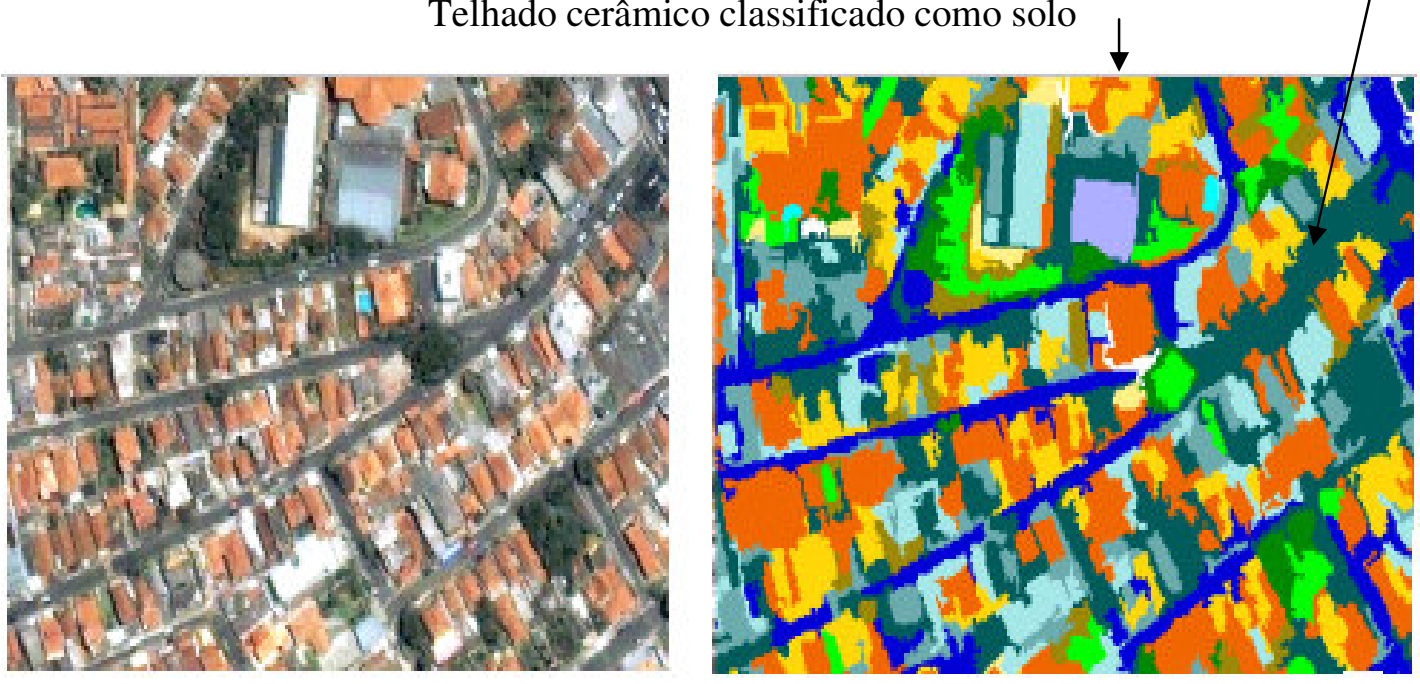

Figura 36. Exemplificação da confusão verificada entre algumas classes.

Visando a redução da confusão entre as classes e, conseqüentemente, a melhoria do resultado geral da classificação, a imagem classificada foi convertida de matriz para vetor e exportada para 0 software ArcGis 9 para ser retrabalhada.

A Figura 37 representa uma área para onde é possível reconhecer, com relativa facilidade, feições características como eixos de ruas, telhados cerâmicos e de amianto e áreas verdes. 


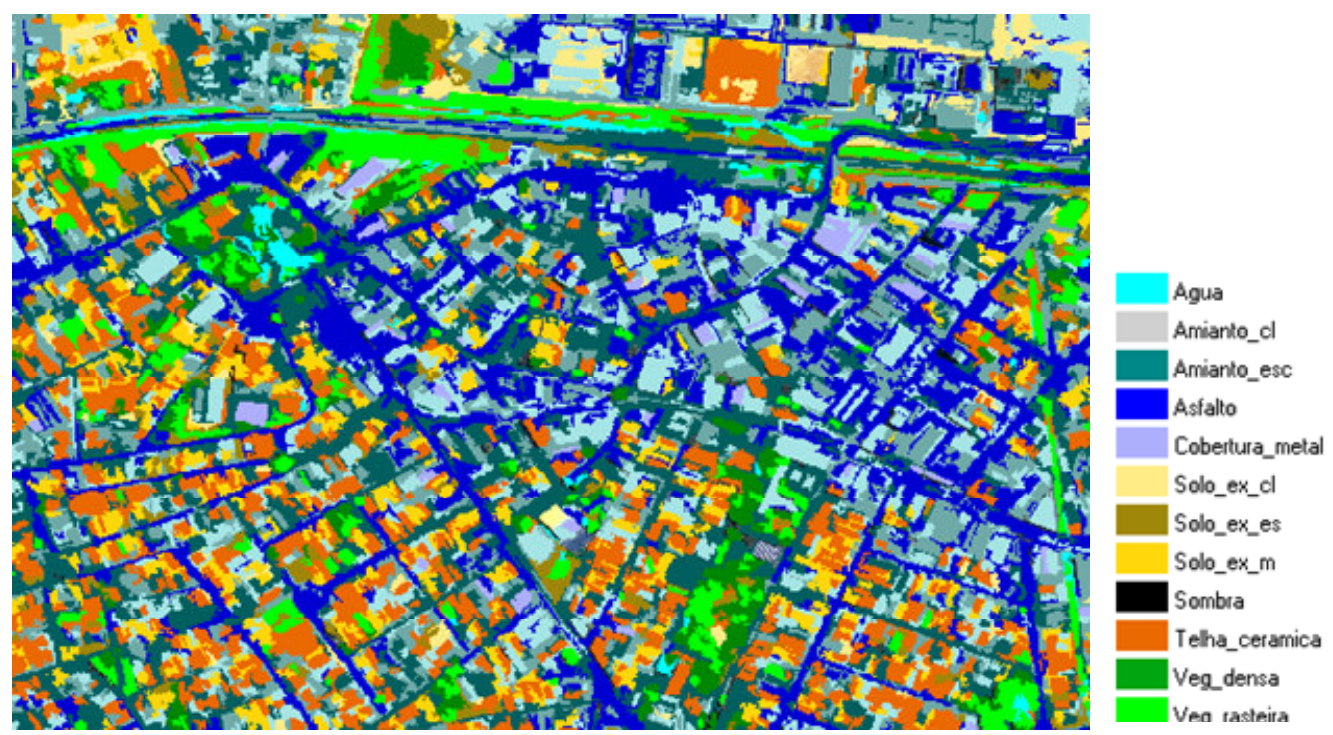

Figura 37. Resultado da classificação por regiões, destacando a presença de determinadas feições, como eixo de ruas, telhados e áreas verdes.

Uma análise mais detalhada, comparando-se a classificação com a imagem original, permite verificar a existência de confusão entre determinadas classes, como solo exposto e telhado cerâmico e asfalto com amianto.

Para melhor estimar o desempenho desta classificação, bem como quantificar o grau de confusão existente e entre quais classes, foi gerada uma matriz de confusão permitindo essas e outras análises, representada pela Tabela 01. 
Tabela 01. Matriz de confusão da classificação por regiões.

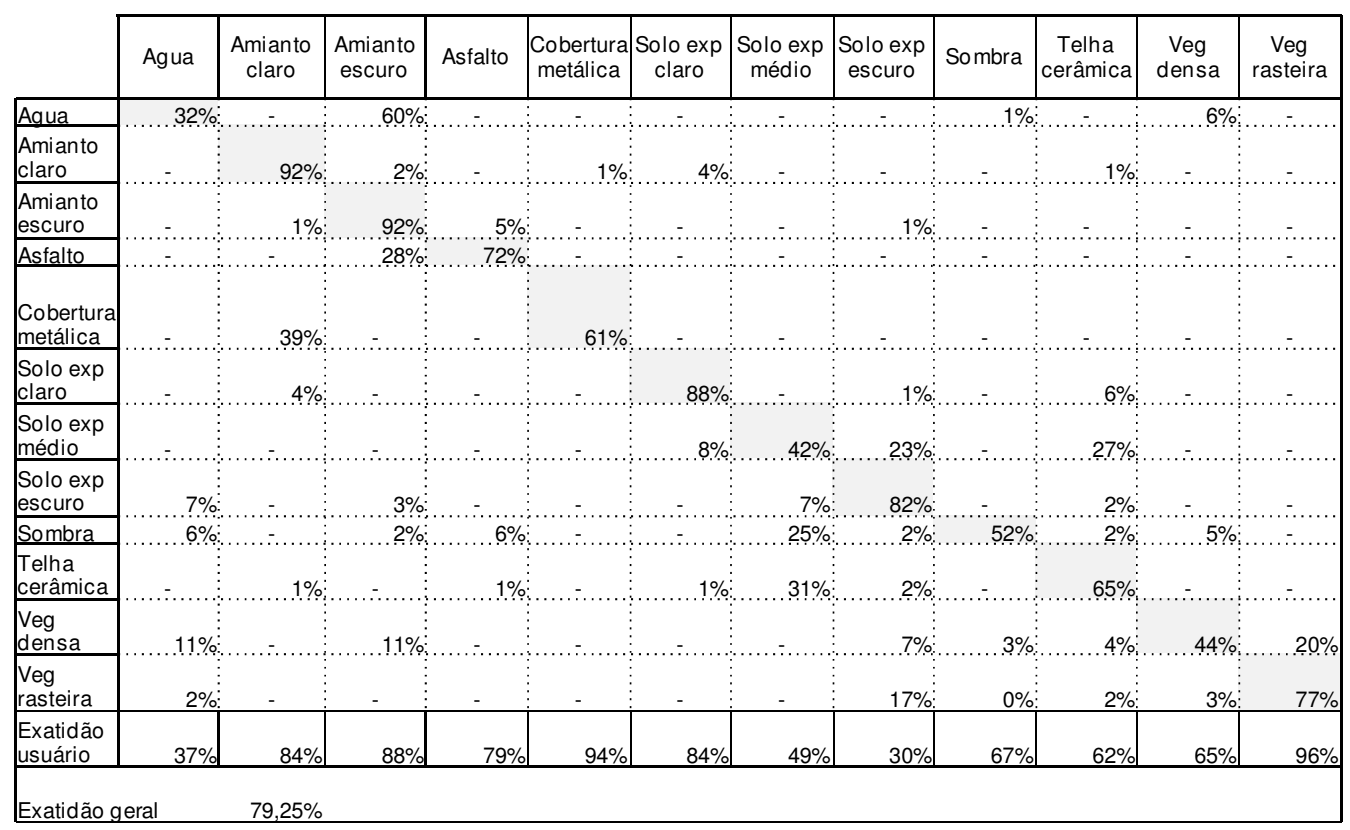

A exatidão geral foi de $79,25 \%$, considerada boa. Todavia, analisando-se classe à classe, percebe-se que algumas tiveram bom desempenho, como as duas categorias de amianto; outras medianas, como telha e asfalto, e outras ruins, como água e vegetação densa. $\mathrm{O}$ índice de exatidão geral não reflete uma situação de bom desempenho em todas as classes, algumas classes muito bem avaliadas compensaram o baixo desempenho de outras.

Como a finalidade do presente trabalho é o mapeamento da cobertura do solo, todas as classes possuem a mesma importância e devem apresentar um resultado final de classificação razoável. Apesar da avaliação geral ser satisfatória, deu-se continuidade no processo visando melhorar a classificação de algumas categorias.

\subsection{Pós-Classificação}

A conversão de raster para vetor enriqueceu a análise gerando novos dados para os polígonos, como área, perímetro e topologia, não disponíveis 
quando os mesmos estão em seu formato original. Contudo, polígonos vizinhos pertencentes a mesma categoria foram agrupados num único segmento, perdendo-se assim os dados da segmentação original. Diante desta situação, optou-se em se trabalhar com o mapa temático em virtude das informações adicionais a ele agregadas, mas cientes da presença de viés na formação dos polígonos.

\subsubsection{Análise dos resultados preliminares}

A análise inicial dos resultados obtidos na classificação permitiu identificar que as categorias solo exposto claro, amianto claro e amianto escuro apresentaram um ótimo resultado, tanto na exatidão do produtor $88 \%$, 92\% e $92 \%$ respectivamente, como na do usuário - $84 \%$, $84 \%$ e $88 \%$ respectivamente. Isso significa dizer que menos de $12 \%$ dos polígonos dessas categorias foram atribuídos a outras classes. Da mesma forma, menos de $16 \%$ dos polígonos a elas atribuídos, na verdade, pertencem a outra classe. Entendeu-se, assim, que não havia necessidade de aprimorar o resultado destas categorias.

A cobertura metálica apresentou um resultado razoável. Todavia, todo o erro de omissão, 39\%, concentrava-se na classe amianto claro. Esta relação sugeriu melhorar $\circ$ resultado, identificando características pertinentes aos polígonos omitidos que pudessem ser aplicadas numa reclassificação.

A situação descrita acima foi verificada também com a classe asfalto, mas o erro de omissão de $28 \%$ concentrou-se na classe amianto escuro. Devido à semelhança no comportamento espectral destes materiais, ilustrado na Figura 4, uma confusão já era esperada, embora o resultado geral do amianto escuro tenha superado as expectativas.

A classe telha cerâmica apresentou um resultado substancial, $65 \%$, mas um erro de comissão considerável, $29 \%$, em relação a classe solo exposto médio. Uma confusão entre essas classes também já era esperado. Como a classe solo exposto médio apresentou resultados mais críticos, com 
exatidão do produtor de $42 \%$ e de usuário de $49 \%$, procurou-se trabalhar essas duas classes em conjunto, de forma que uma melhoria no resultado de uma alavancasse, conseqüentemente, o resultado da outra.

As classes água e vegetação densa foram as que apresentaram os piores resultados, com $32 \%$ e $44 \%$ de exatidão do produtor, respectivamente, demandando também uma análise mais minuciosa para melhoria de seus índices.

Com relação às classes vegetação rasteira e sombra, após análise de seus respectivos resultados, optou-se por não alterá-las. A vegetação rasteira teve um bom resultado na exatidão do produtor e do usuário, $77 \%$ e $96 \%$, sendo que seu maior índice de confusão foi com a classe solo exposto escuro, que também apresentou bons resultados, e assim, decidiu-se mantêla inalterada. A classe sombra, apesar de seu desempenho de exatidão do produtor de $52 \%$ e de usuário de $67 \%$ serem considerados moderados, a opção de não mexê-la baseou-se também em sua pouca representatividade na cena, correspondendo a $1 \%$ da área usada como referência.

\subsubsection{Critérios de reclassificação}

\subsubsection{Asfalto}

A depreciação causada pelo agrupamento dos segmentos vizinhos de mesma classe, ocorrida com a conversão da classificação para o formato vetor, pôde ser bem sentida quando procurou-se identificar as características dos polígonos da classe asfalto que foram enquadrados como amianto escuro.

O amianto escuro é um material encontrado com muita freqüência na paisagem urbana, principalmente como telhado, além de seu comportamento espectral assemelhar-se muito com o asfalto. Juntando-se os seguintes fatores: a) amianto usado como cobertura, geralmente, possui uma relação de vizinhança com o eixo de ruas; b) o eixo de ruas é formado, na maioria da sua extensão, por asfalto; c) $28 \%$ dos polígonos da classe 
asfalto foram classificados como amianto escuro e, d) segmentos vizinhos de mesma classe foram agrupados num único polígono, resultou numa classificação em que a classe amianto escuro aparece em grandes proporções.

Procurou-se então levantar o perfil dos polígonos corretamente classificados como asfalto, de acordo com os atributos disponíveis de área e perímetro. Nova consulta foi feita, mas dessa vez incluindo uma condição de que apenas fossem selecionados polígonos com área igual ou menor a $2.200 \mathrm{~m}^{2}$, medida correspondente à media da área dos polígonos de referência da classe asfalto, acrescido do desvio padrão. O resultado pode ser verificado na Tabela 02.

Tabela 02. Matriz de erro após aplicação de ajuste para classe asfalto.

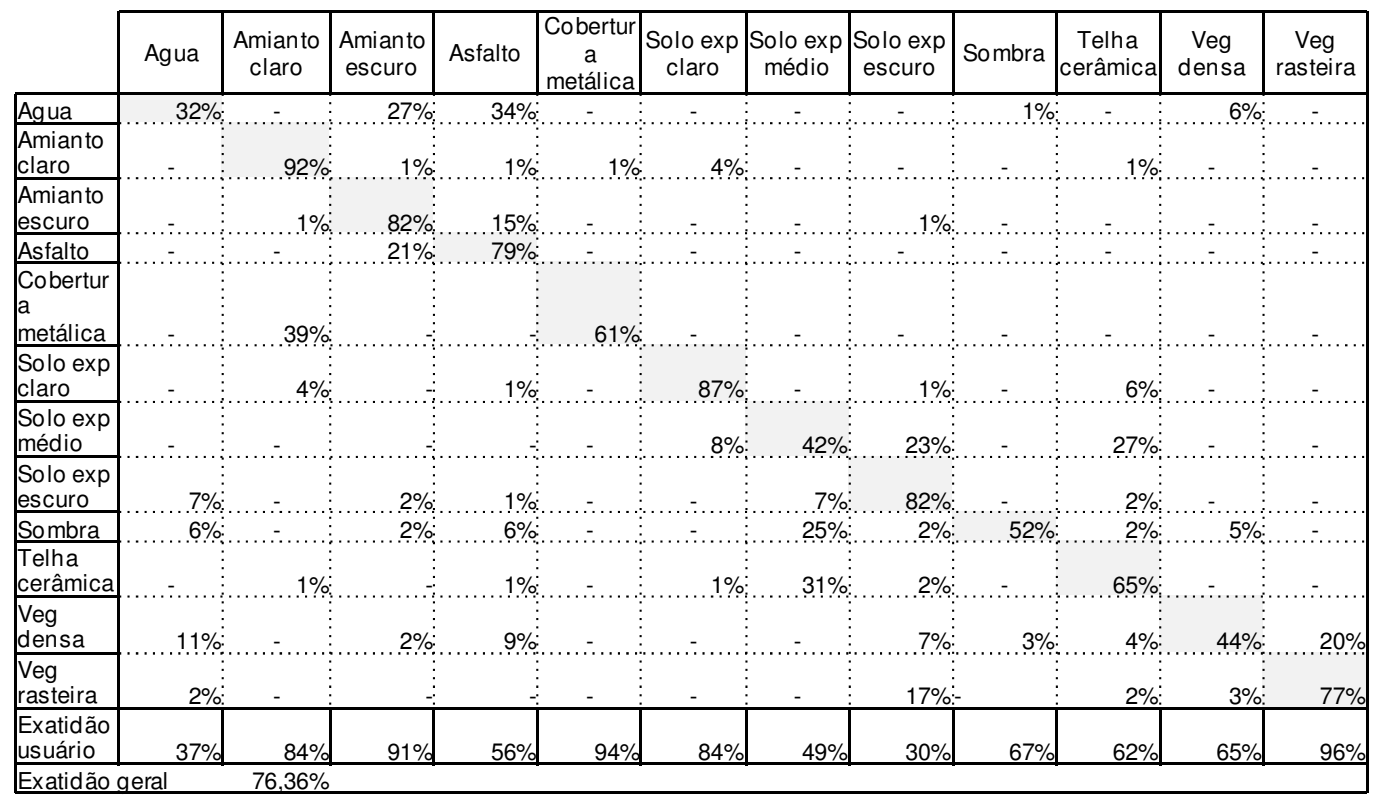

A classe asfalto melhorou $7 \%$, mas amianto escuro caiu $10 \%$, mas mesmo com exatidão de $82 \%$ permanece bem avaliado. A exatidão do usuário teve uma queda considerável em virtude de asfalto assumir para si parte do erro de comissão anteriormente da atribuída a classe amianto escuro. A exatidão geral apresentou ligeira queda, ocasionada pela queda na avaliação do amianto escuro. Todavia, como espera-se melhorar o índice 
de exatidão geral com a correção de outras classes, e conseguiu-se melhorar o desempenho da classe asfalto, o critério foi considerado válido.

\subsubsection{Solo exposto médio e telha cerâmica}

A confusão apresentada entre essas duas classes é decorrente da presença da argila na composição de ambas. Desta forma, a utilização apenas de dados espectrais para separá-las adequadamente não tem se mostrado eficaz.

A primeira premissa empregada foi que telha cerâmica e solo exposto podem ocorrer dentro das quadras, mas só solo exposto pode existir fora delas também. Logo, todo polígono classificado como telha cerâmica não contido nos polígonos representativos de quadra deveriam ser classificados como solo exposto médio. Esta simples verificação contextual provocou uma considerável melhora no desempenho de solo exposto médio, tanto na exatidão do produtor como na do usuário, além de uma sensível melhora na exatidão geral, conforme pode ser visto na Tabela 03 .

Tabela 03. Matriz de erro após aplicação de ajuste para classe asfalto e solo exposto médio.

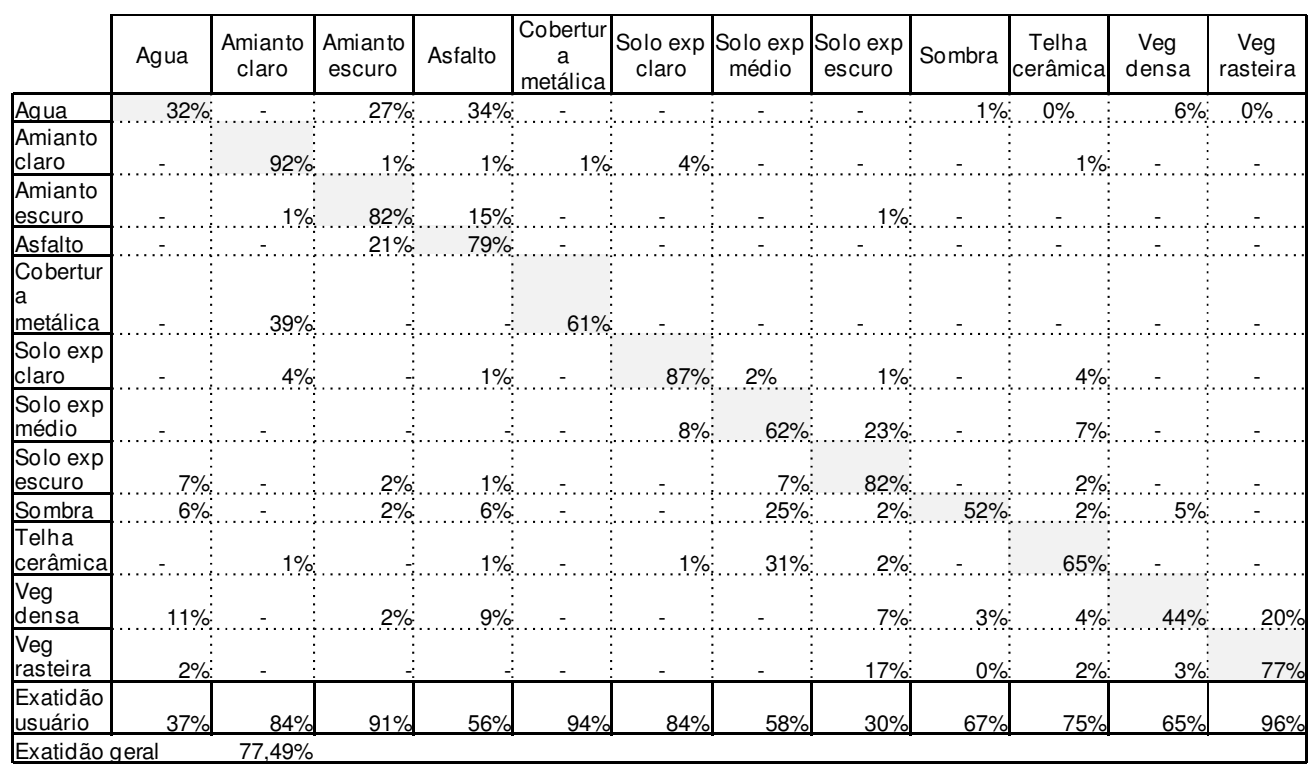


Apesar dessa considerável melhora na classe solo exposto médio, pretendia-se ainda melhorar o resultado da classificação de telha cerâmica, principalmente por grande parte do erro de omissão, 31\%, estar concentrado na classe solo exposto médio. Nova análise de contexto foi feita, mas nenhuma outra relação topológica foi capaz de identificar uma distinção entre as classes.

Partiu-se então para análise dos atributos de área e perímetro. Medidas estatísticas básicas, como média e desvio padrão, não indicaram nenhuma distinção considerável entre as classes. Todavia, percebeu-se que a relação área/perímetro era mais constante na classe telha e mais variável na classe solo exposto médio, conforme Gráficos 1 e 2.

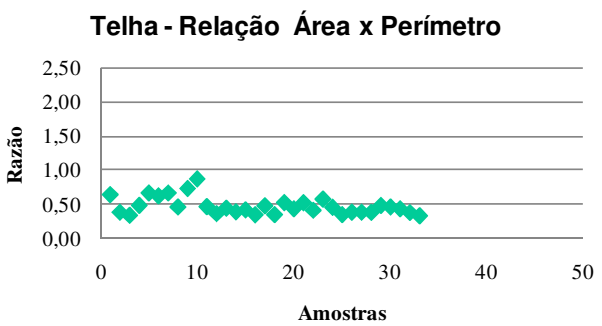

Gráfico 1

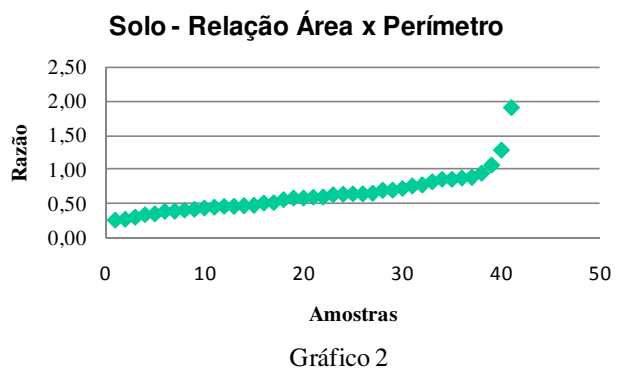

Gráfico 1. Relação entre os valores de área e perímetro nos polígonos de referência para classe telha cerâmica; Gráfico 2. Relação entre os valores de área e perímetro nos polígonos de referência para classe solo exposto médio.

Diversas simulações foram feitas para selecionar o intervalo de razão que melhor caracterizasse a classe telha cerâmica, tendo se chegado ao intervalo de 0,35 a 0,49. Desta forma, novo critério foi aplicado, definindo que polígonos classificados como solo exposto médio, cuja razão entre área e perímetro estivesse no intervalo de 0,35 a 0,49 deveria ser classificado como telha cerâmica. $O$ resultado pode ser verificado na Tabela 04 . 
Tabela 04. Matriz de erro após aplicação de ajuste para classe asfalto,solo exposto médio e telha cerâmica.

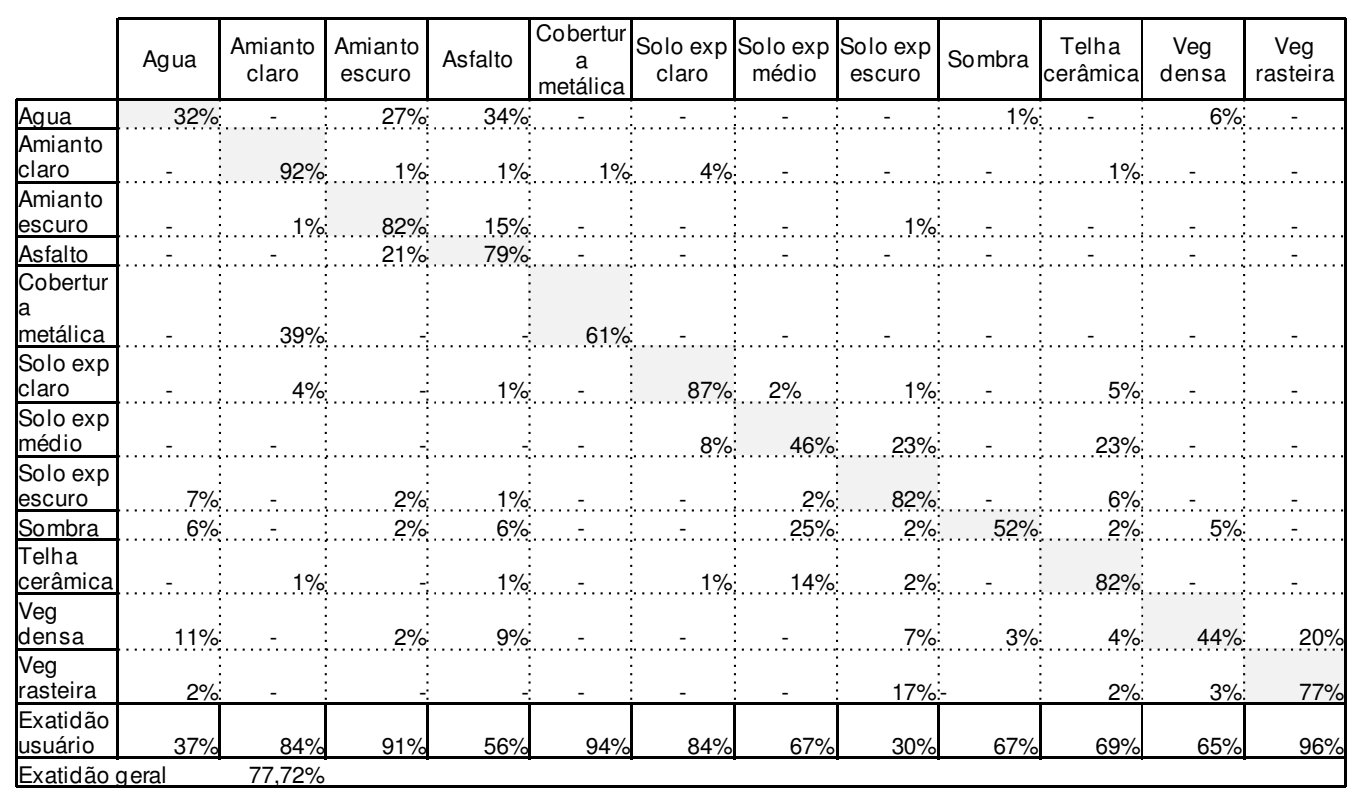

A avaliação da classe telha cerâmica melhora consideravelmente, passando de $65 \%$ para $82 \%$, mas a classe solo exposto médio volta ao patamar anterior de $46 \%$. A exatidão geral permaneceu quase inalterada. Devido aos novos resultados obtidos para telha cerâmica, optou-se por manter esse critério, mesmo com a desvalorização do solo exposto médio. Considerou-se também que, embora o presente trabalho não pretenda priorizar nenhuma classe, solo exposto é uma categoria de cobertura do solo mais suscetível à mudanças do que telha cerâmica. Desta forma, acredita-se que um mapeamento com maior precisão para classe telha seria de maior valia do que se mantivesse os índices da Tabela 03.

\subsubsection{3 Água}

A água em ambientes urbanos é uma categoria de difícil caracterização espectral, pois sofre grande influência do material nela submergido. Para categoria água já era esperado baixo índice de exatidão, pois boa parte de sua representatividade na área do projeto refere-se ao 
Tietê, conhecido por seu alto grau de poluição. Por outro lado, a classe teve seu erro de omissão concentrado em apenas duas categorias semelhantes entre si, amianto escuro (27\%) e asfalto (34\%).

Uma das características do rio, ao longo de quase toda sua extensão, é a sua relação de adjacência com as classes vegetação rasteira e solo exposto claro, médio e escuro.

Desta forma, o primeiro critério utilizado foi a seleção de polígonos das classes asfalto e amianto escuro que tivesse adjacência com vegetação rasteira. Todavia, o resultado da seleção apresentou polígonos de grande extensão, abrangendo tanto trechos do rio como também eixos viários numa proporção maior que a de água.

Aplicou-se então, sobre essa seleção, um limite de perímetro entre 500 e $600 \mathrm{~m}$. O resultado pode ser visto na Tabela 05.

Tabela 05. Matriz de erro após aplicação de ajuste para classe asfalto,solo exposto médio, telha cerâmica e água.

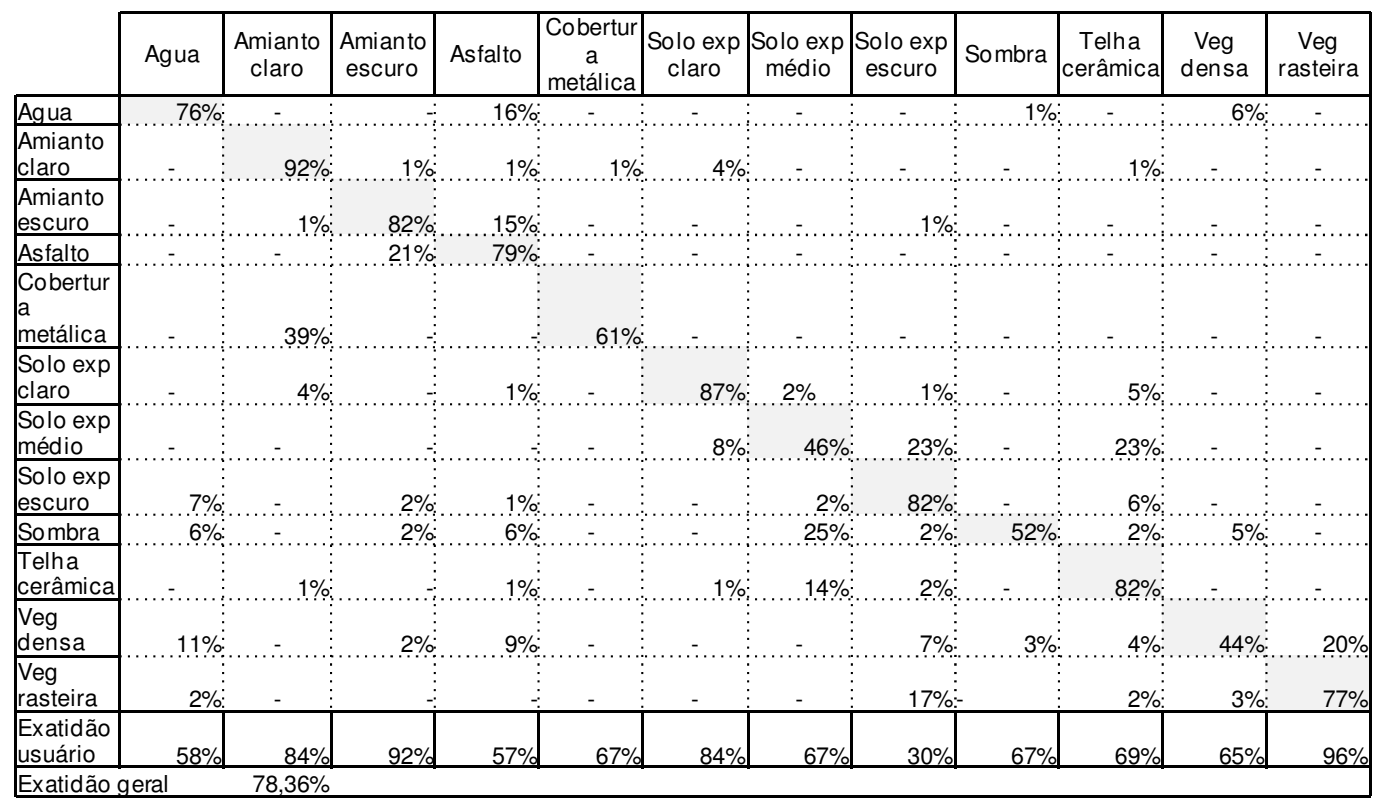

Como resultado, obteve-se uma melhora significativa no desempenho da classe água, tanto na exatidão do produtor, de $32 \%$ para $76 \%$, como na exatidão do usuário, de $37 \%$ para $58 \%$. Uma sensível melhora pôde ser 
observada na exatidão do usuário das classes amianto escuro e asfalto. A exatidão geral teve um aumento de quase $1 \%$.

\subsubsection{Vegetação densa}

A maior parte da confusão verificada para classe vegetação densa está na sua variante, vegetação rasteira (20\%). Para melhorar a definição da classe foi gerada uma imagem NDVI. Todavia, quando utilizada entre as duas categorias, encontrou-se dificuldade em definir um escalonamento satisfatório de valores para os dois diferentes estágios da vegetação. Procurou-se então, utilizar o NDVI na identificação de áreas vegetadas, mas classificadas em outras categorias que não vegetação rasteira.

Das classes que se confundiram com vegetação densa, água e solo exposto escuro podem vir a apresentar resquícios de vegetação na sua composição, apesar de distintas entre si. Sendo assim, a sobreposição de polígonos destas classes com o do NDVI poderia ocorrer, mas sem caracterizar, necessariamente, um erro na classificação. Todavia, asfalto e amianto escuro, outras duas classes que se confundiram com vegetação densa, não deveriam responder positivamente na geração de imagem NDVI. Desta forma, decidiu-se concentrar esforços no erro de comissão destas duas classes, definindo como vegetação densa os polígonos atribuídos asfalto e amianto escuro contidos em áreas com valor de NDVI acima de 18. O resultado é apresentado na Tabela 06. 
Tabela 06. Matriz de erro após aplicação de ajuste para classe asfalto, solo exposto médio, telha cerâmica, água e vegetação densa.

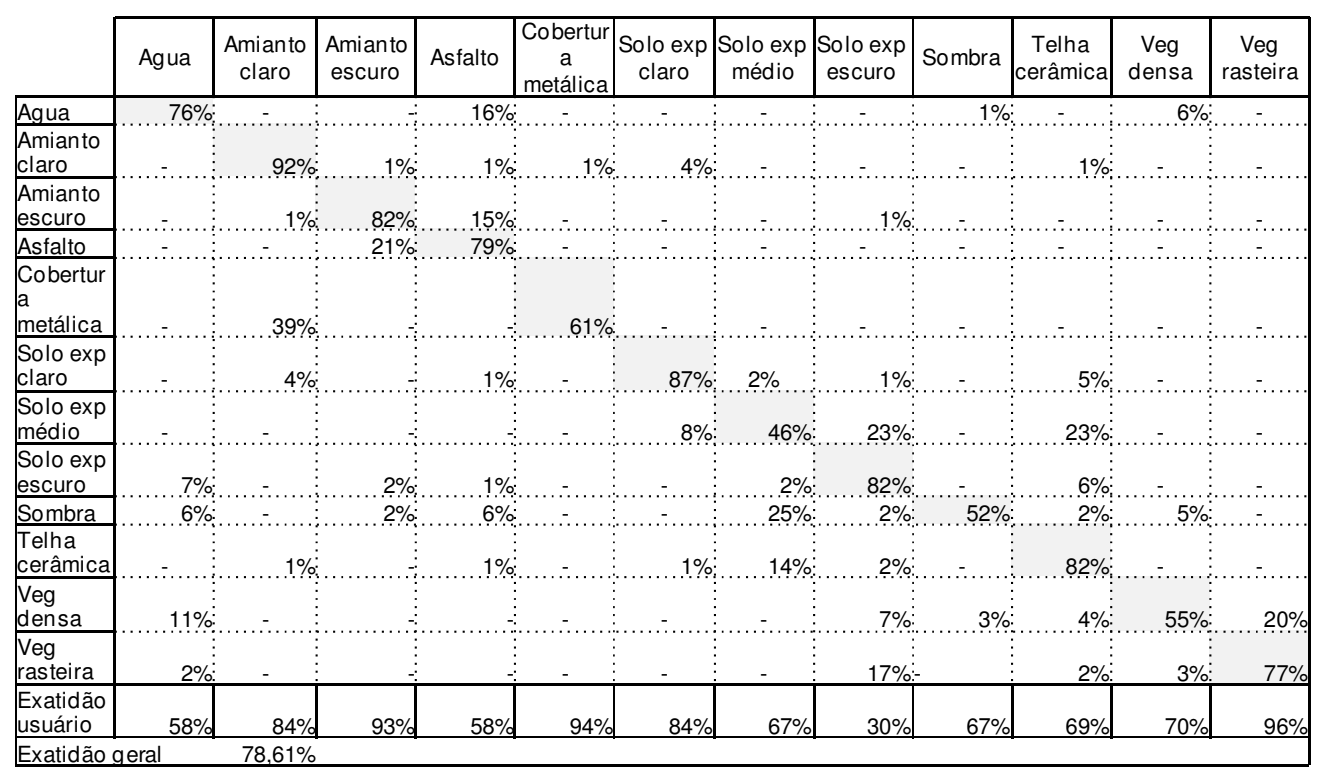

Analisando-se a tabela, a aplicação deste critério eliminou o erro de comissão das classes asfalto e amianto escuro em relação a vegetação densa, resultando no ganho da exatidão do usuário destas classes para $58 \%$ e 93\%, respectivamente. Já a classe vegetação densa teve uma significativa melhora, passando de $44 \%$ para $55 \%$. A exatidão geral, à exemplo do que ocorreu com os critérios anteriores, apresentou sensível melhora, mas ainda sem atingir o mesmo índice da classificação original.

\subsubsection{Resultados finais}

A classificação final é ilustrada pela Figura 38. Visualmente, não destaca alterações significativas em relação a classificação inicial. Analisando mais detalhadamente, pode-se perceber algumas diferenças em áreas antes classificadas como amianto escuro e agora como asfalto. $\mathrm{O}$ mesmo pode ser observado para solo exposto médio e telha cerâmica, conforme ilustra Figura 39. 


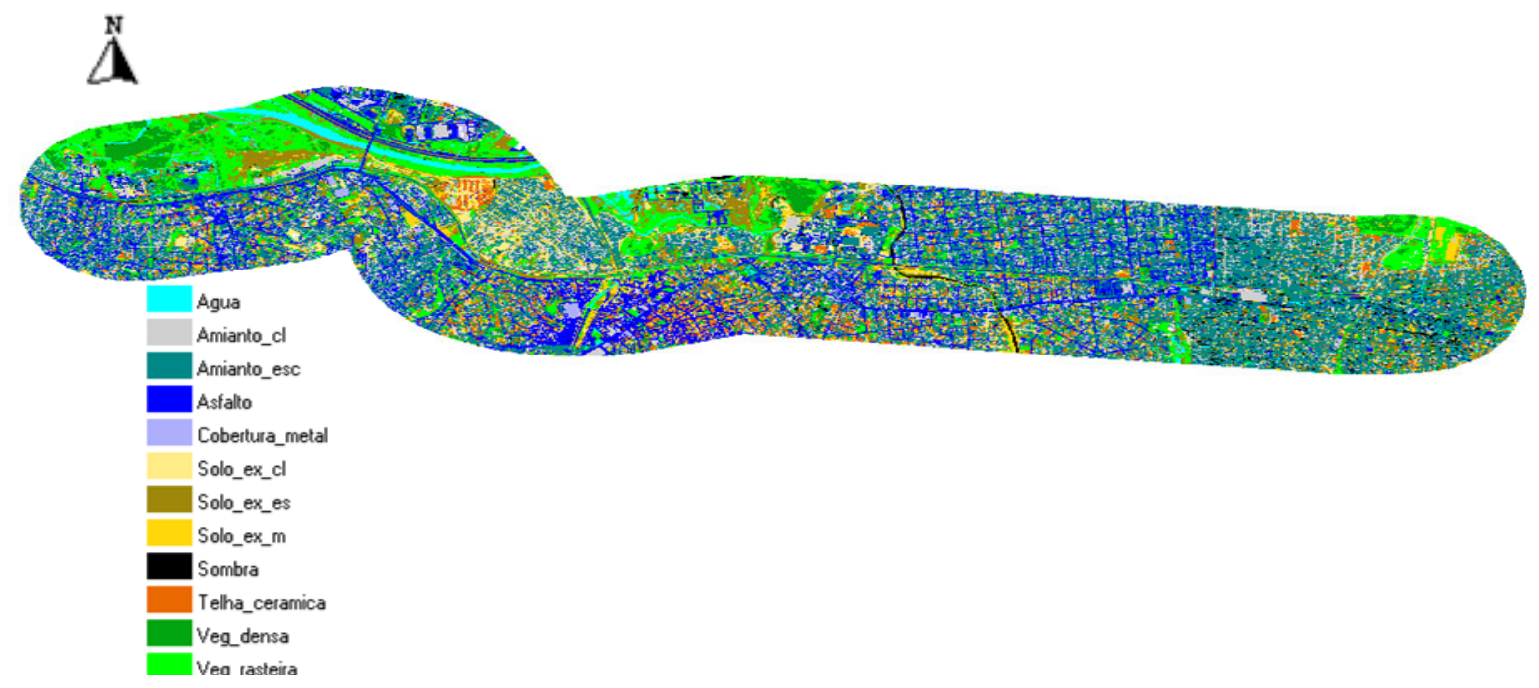

Figura 38. Classificação final.
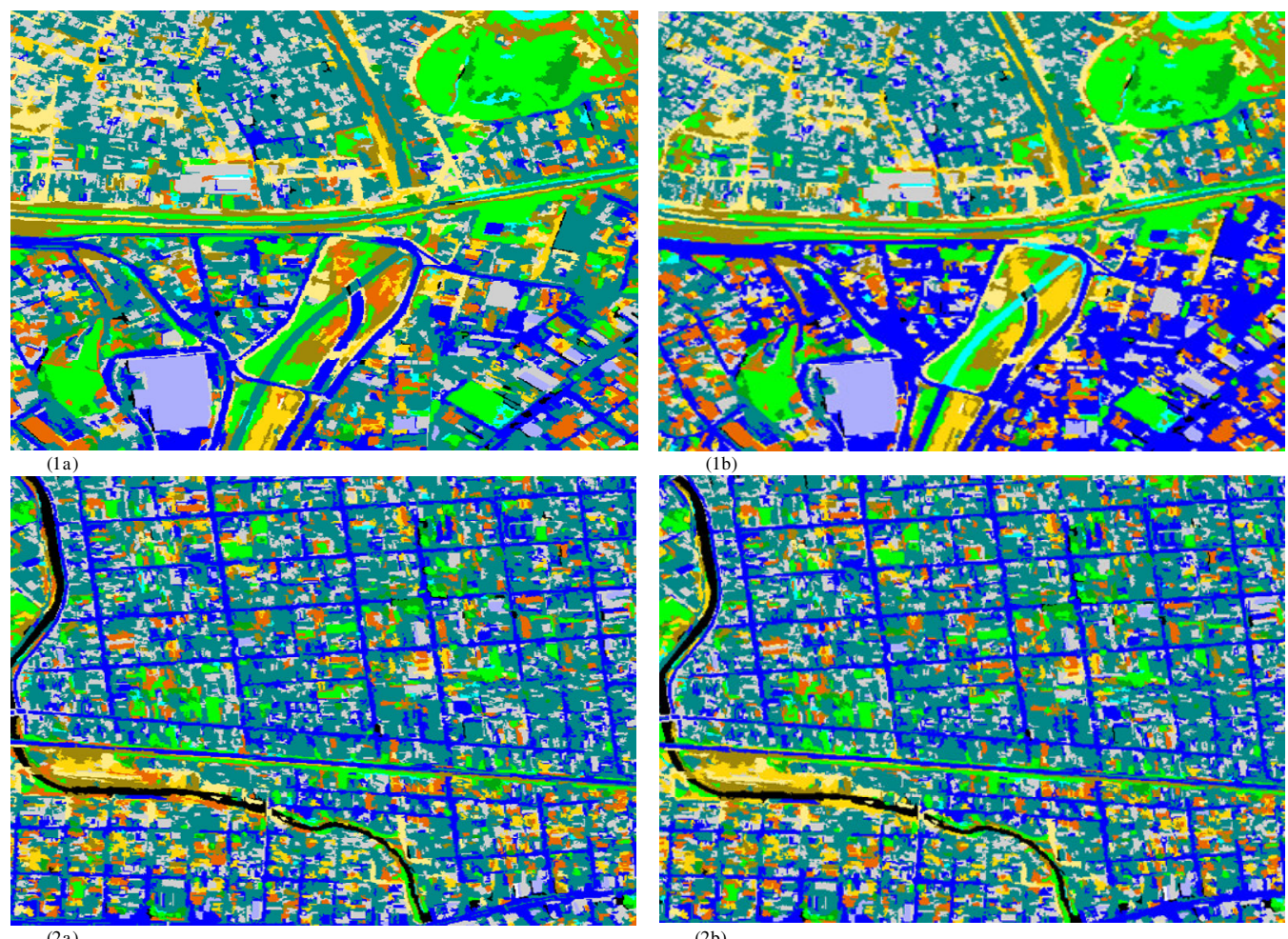

(2a)

(2b)

Figura 39. Duas cenas em detalhe, onde 1a e 2a correspondem à primeira classificação e 1b e 2b correspondem à classificação final.

\subsection{Avaliação dos resultados finais}


As classificações e critérios desenvolvidos até aqui foram avaliados apenas pelos índices mais simples extraídos pela matriz de confusão, como exatidão geral, do usuário e do produtor.

Uma vez tendo-se chegado à melhor combinação de critérios e resultados, de acordo com os índices acima mencionados, aplicou-se então os cálculos para índices de desempenho chegando-se a avaliação final da classificação.

A Tabela 07 apresenta os valores finais de classificação, para os quais chegou-se ao valor de 0,74 para coeficiente Kappa. 
Tabela 07. Matriz de erro sobre a qual foi calculado o coeficiente Kappa.

\begin{tabular}{|c|c|c|c|c|c|c|c|c|c|c|c|c|c|c|c|c|c|c|c|c|c|c|c|c|c|c|}
\hline & $\begin{aligned} A \\
\text { Área }(\mathrm{m} 2)\end{aligned}$ & $\%$ & \begin{tabular}{|l|l|} 
Amian \\
Area $(\mathrm{m} 2)$
\end{tabular} & $\begin{array}{c}\text { claro } \\
\% \\
\end{array}$ & \begin{tabular}{|l|} 
Amianto \\
Area (m2)
\end{tabular} & $\begin{array}{r}\text { escuro } \\
\%\end{array}$ & \begin{tabular}{|l|} 
Área \\
As 21
\end{tabular} & $\%$ & Cobertur & $\begin{array}{c}\text { metálica } \\
\%\end{array}$ & \begin{tabular}{|l|l|} 
Solo ex \\
Area $(\mathrm{m} 2)$
\end{tabular} & $\begin{array}{c}\text { claro } \\
\%\end{array}$ & \begin{tabular}{|l|l|} 
Solo ex \\
Area $(\mathrm{m} 2)$
\end{tabular} & $\frac{m e ́ d i o ~}{\%}$ & 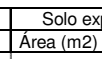 & $\begin{array}{c}\text { escuro } \\
\%\end{array}$ & Área (mor) & $\%$ & \begin{tabular}{|l|l|l|} 
Tella \\
Area $(m 2)$ \\
\end{tabular} & $\begin{array}{l}\frac{a}{3} \text { mica } \\
\%\end{array}$ & $\begin{array}{l}\text { Vegetac } \\
\text { Area }(\mathrm{m})\end{array}$ & $\begin{array}{c}\text { o densa } \\
\%\end{array}$ & $\begin{array}{l}\text { Vegetara } \\
\text { Area ( } 2\end{array}$ & $\begin{array}{l}\text { rasteira } \\
\%\end{array}$ & $\begin{aligned} \text { Tot } \\
\text { Arraa } \\
\end{aligned}$ & $\%$ \\
\hline Agua & & & & & & & & & & & & & & & & & & & & & & & & & & \\
\hline Amianto clarc & & & 67.585 & 0,92 & 721 & 0,01 & 925 & 0,01 & 922 & 0,01 & 2.813 & 0,04 & & & & & & & 800 & 0,01 & & & & & 73.766 & 0,11 \\
\hline $\begin{array}{l}\text { elscuro } \\
\text { Asfation }\end{array}$ & 636 & & $\begin{array}{r}1.462 \\
54\end{array}$ & $\begin{array}{l}0,01 \\
0,00\end{array}$ & \begin{tabular}{|l}
202.331 \\
14.979 \\
\end{tabular} & $\begin{array}{r}0,82 \\
0,21 \\
\end{array}$ & $\begin{array}{l}\quad 37.265 \\
156.728 \\
\end{array}$ & $\begin{array}{l}0,15 \\
0,79\end{array}$ & & & & - & 566 & & 2.699 & 0,01 & 342 & & 936 & & 163 & & & & $\begin{array}{r}246.399 \\
71.761\end{array}$ & $\begin{array}{l}0,35 \\
0,10\end{array}$ \\
\hline $\begin{array}{l}\begin{array}{l}\text { oobertura } \\
\text { metalica }\end{array} \\
\end{array}$ & & & 9.387 & 0,39 & & $\dot{\tau}$ & - & - & 14.396 & 0,61 & & & & & & & & & & & & & & & 23.783 & 0,03 \\
\hline $\begin{array}{l}\text { Solo } \\
\text { claro }\end{array}$ & & - & 1.712 & 0,04 & & & 383 & 0,01 & & - & 33.276 & 0,87 & 752 & 0,02 & 335 & 0,01 & & & 1.738 & 0,05 & & & & & 38.197 & 0,05 \\
\hline $\begin{array}{l}\begin{array}{l}\text { Solo oxp } \\
\text { medio }\end{array} \\
\text { madio }\end{array}$ & - & - & & - & - & . & 5 & - & & & 2.934 & 0,08 & 17.968 & 0,46 & 8.916 & 0,23 & & & 8.881 & 0,23 & & & & & 38.704 & 0,06 \\
\hline $\begin{array}{l}\text { Soloe exp } \\
\text { escuro }\end{array}$ & 1.291 & 0,07 & & & 314 & 0,02 & 121 & 0,01 & & & & & 408 & 0,02 & 14.108 & 0,82 & & & 1.037 & 0,06 & & & & & 17.279 & 0,02 \\
\hline & 231 & 0,06 & & & 86 & 0,02 & 223 & 0,06 & & & & & 889 & 0,25 & & 0,02 & 1.883 & 0,52 & 62 & 0,02 & 190 & 0,05 & & & 3.621 & 0,01 \\
\hline mica & - & - & 238 & 0,01 & - & - & 393 & 0,01 & & & 455 & 0,01 & 6.235 & 0,14 & 798 & 0.02 & & - & 37.442 & 0,82 & & & & & 45.561 & 0,07 \\
\hline sa & 1.696 & 0,11 & & - & & - & & - & & & & . & & & 1.157 & 0,07 & 491 & 0,03 & 632 & 0,04 & 8.860 & 0,55 & 3.248 & 0,20 & 16.084 & 0,02 \\
\hline etaçao & .792 & 0,02 & 2 & & & & 98 & & 1531 & & $\frac{85}{3502}$ & & 0689 & & $\frac{18.764}{4.825}$ & 0,17 & 1 & & $\begin{array}{r}2.734 \\
5\end{array}$ & 0,02 & 851 & 0,03 & 87.057 & 0,77 & 130.507 & 18 \\
\hline
\end{tabular}




\section{CONCLUSÕES}

O principal objetivo deste trabalho foi o mapeamento da cobertura do solo ao longo da faixa de domínio de trem metropolitano e suas adjacências, usando imagem de satélite de alta resolução espacial e técnica de classificação baseada em objetos. Analisando o resultado final, conclui-se que o objetivo foi cumprido, comprovando-se a aplicabilidade de imagem de satélite de alta resolução, aliada às técnicas de processamento de imagem, como suportes ao planejamento e gerenciamento do entorno da ferrovia.

A segmentação possibilitou o delineamento de feições num nível de detalhamento até superior ao que se precisava, pois mesmos objetos de menores dimensões foram divididos em mais de um segmento. Todavia, ainda demanda considerável esforço computacional, o que pode vir a ser um impeditivo para se trabalhar áreas de maiores dimensões.

A classificação final apresentou um índice de desempenho satisfatório, permitindo identificar e mensurar a presença dos diversos materiais encontrados às margens da linha ferroviária. A classificação inicial, produto do algoritmo Bhattacharyya, apresentou um resultado acima das expectativas, podendo ser melhorado com aplicação de regras e critérios para identificação das classes.

Quanto à caracterização das classes, estas podem ser agrupadas em três categorias distintas, de acordo com seu grau de identificação: a) as facilmente caracterizadas apenas pela sua resposta espectral, como amianto claro, vegetação rasteira e solo exposto escuro; b) as que demandaram análise mais apurada de seus atributos e sua contextualização na cena para refinamento de sua identificação, como asfalto, amianto escuro, telha cerâmica e solo exposto médio e, c) as que não se conseguiu delimitar com base apenas nos atributos disponíveis, como cobertura metálica e sombra. 
Observou-se que informações contextuais são altamente úteis no processo de caracterização e classificação dos materiais. Muito embora este trabalho tenha utilizado apenas dados de quadras e logradouros, as prefeituras, de modo geral, possuem uma variedade interessante de dados passíveis de serem integrados numa análise de mapeamento urbano. Todavia, há dificuldades de obtenção, adaptação e conversão dessas bases de dados.

A diversidade de arranjos urbanos encontrados na área do projeto parque ecológico, indústrias, residências e ocupações irregulares - foi um dos pontos atrativos para o desenvolvimento do trabalho. Entretanto, num trabalho de classificação da cobertura do solo, essa variedade dificultou a criação de regras ou critérios aplicáveis satisfatoriamente à toda região.

O mapeamento da cobertura do solo numa área limite em torno da linha férrea pode ser de grande valia para as concessionárias de ferrovias. Embora o presente trabalho não tenha se prestado a essa finalidade, às diversas classes de cobertura podem ser atribuídos pesos de forma a classificar as regiões também com relação ao seu grau de risco para a ferrovia. Exemplificando, vegetação rasteira e solo exposto podem não ser preocupantes para uma ferrovia, mas a existência de telha cerâmica ou de amianto numa determinada proximidade do eixo férreo sinalizar um perigo de invasão, ou necessidade de se tomar medidas preventivas de segurança.

\subsection{Recomendações para trabalhos futuros}

O presente trabalho não utilizou softwares específicos para classificação orientada a objeto, os quais poderiam gerar produtos finais mais fidedignos aos objetos imageados. Desta forma, outros recursos poderiam ser empregados na melhoria de resultados, como combinação de diferentes níveis de segmentação. Da mesma forma, outros atributos que poderiam auxiliar na caracterização das classes, como forma e textura, poderiam ser explorados. 
A redução dos segmentos originais quando da conversão de imagem classificada para mapa temático poderia ser remediada criando-se mais classes intermediárias com características próximas ao do amianto escuro, que foi a classe que mais teve seus polígonos agrupados.

Transformações matemáticas, como análise de componente principal, poderiam ser usadas em conjunto com as bandas espectrais nas fases de segmentação e classificação, como dados adicionais pra caracterização de classes específicas, mas o software utilizado (SPRING 4.2) não permitiu essa integração. Outros aplicativos podem oferecer essa integração e prover uma melhora no resultado da classificação inicial ou final.

A utilização dos dados de altura dos objetos, gerada a partir de um modelo digital de elevação, poderia auxiliar na distinção de elementos constituídos de material semelhante, mas empregados em estruturas diferentes, como telha cerâmica (objeto edificado) e solo exposto (nível do solo). 


\section{REFERÊNCIAS BIBLIOGRÁFICAS}

ALBERTI, M.; COE, S.; WEEKS, R. Land Cover Change in Puget Sound Urbanizing Watersheds. In: II GRSS/ISPRS, Berlim, Alemanha. Anais. 2003

ALMEIDA, G. E. S. Análise do índice de instalação de empresas no município de Osasco utilizando sistemas de informação geográfica e análise envoltória de dados - DEA. 2006. 121 p. Dissertação (Mestrado) EPUSP - Escola Politécnica da Universidade de São Paulo, São Paulo, 2006.

ANGEL, A. et. al. (2001) Needs Assessment and Allocation of Imaging Resources for Transportation Planning and Management. NCRST-F YEAR 1, Atlas Research Center, University of Arizona, Tucson, Arizona.

ARONOFF, S. Remote sensing for GIS managers. 1.ed. Redlands, California: ESRI Press, 2005. 487 p.

BELTRAME, A. M. K.; JARDINI, M. G. M.; JACOBSEN, R.; QUINTANILHA, J. A. Análise da vegetação em faixas de servidão de linhas de transmissão de energia elétrica. In: XIII Simpósio Brasileiro de Sensoriamento Remoto, 2007, Florianópolis. Anais... São José dos Campos: INPE, 2007. p. 5579 5586 .

BINS, L.S.; FONSECA, L. M. G.; ERTHAL, G. J.; MITSUO, F. Satellite imagery segmentation: a region gowning approach. In: VIII Simpósio Brasileiro de Sensoriamento Remoto, 1996, Salvador. Anais... São José dos Campos: INPE, 1996. p. 677 - 680.

BLASCHKE, T.; GLÄSSER, C.; LANG, S. Processamento de imagens num ambiente integrado SIG/sensoriamento remoto: Tendências e conseqüências. In: Sensoriamento Remoto e SIG avançados. Ed. BLASCHKE, T.; KUX, H. 2 ed. São Paulo: Oficina de Textos, 2007. p. 11-18.

BOCK, M.; XOFIS, P.; MICHTLEY, J; ROSSNER, G.; WISSEN, M. Objectoriented methods for habitat mapping at multiple scales - Case studies from Northern Germany and Wye Downs, UK. In: Journal of Natural Conservation, v. 12, n. 2-3, p. 78-89, Jul., 2005.

BOSSARD, M.; FERANEC, J.; OTAHEL, J. CORINE land cover technical guide - Addendum 2000. Technical Report, № 40, European Environment Agency, 2000.

BRANDÃO, W.; PARADELLA, W. Uso de imagens RADARSAT-1 para fins de mapeamento de uso da terra e cobertura do solo em ambiente tropical úmido urbano: o caso de Manaus, estado do Amazonas. In: XI Simpósio Brasileiro de Sensoriamento Remoto, 2003, Belo Horizonte. Anais... São José dos Campos: INPE, 2003. p. 2177 - 2184. 
BROWN, D. G. Classification and boundary vagueness in mapping presettlement forest types. In: International Journal of Geographical Information Science, London., v. 12, n. 2, p, 105-129, Mar., 1998.

BURROUGH, P. A.; MCDONNELL, R. A. Principles of geographical information systems: Spatial information systems and geostatistics. 2. ed. New York: Oxford University Press, 1998. 333 p.

CAMPBELL, J. B. Visual interpretation of aerial imagery. In: Remote sensing for GIS managers. Ed. ARONOFF, S. 1.ed. Redlands, California: ESRI Press, 2005. p. 259-285.

CARNEIRO Filho, Afonso (2006). Visão de governo: projetos em análise no Ministério dos Transportes. Seminário Transporte Interurbano de Passageiros: Desafogando as grandes cidades brasileiras. São Paulo, SP. Disponível em http://www.revistaferroviaria.com.br. Acessado em 10/06/2006.

CARREIRAS, J. B. M.; PEREIRA, J. M. C.; PEREIRA, J. S. Estimation of tree canopy cover in evergreen oak woodlands using remote sensing. Forest Ecology and Management, v. 223, p. $45-53,2006$.

CARVALHO, A. Os trens de passageiros estão entrando no desvio. In: A Tribuna, edição de 20 de junho de 1980, Santos. Disponível em: http://www.novomilenio.inf.br/santos/h0102n3.htm. Acessado em 29/01/2007.

CASTRO, N. Estrutura, desempenho e perspectivas do transporte ferroviário de carga. Pesquisa e Planejamento Econômico, vol 32, ㄲo 2, 2002.

CBTU - COMPANHIA BRASILEIRA DE TRENS URBANOS. Operadoras Brasileiras. Disponível em http://www.cbtu.gov.br/. Acessado em 12/02/2007.

CICCHETTI, D. V.; FLEISS, J. L. Inference about weighted Kappa in the nonnull case. Applied Psychologial Measurement, v. 2 p. 113-117, 1978.

CORRÊA, M. S. O achador-geral da República. In: Piauí, no 4, ano 1, p. 1619, 2007.

CPTM - COMPANHIA PAULISTA DE TRENS METROPOLITANOS. Disponível em http://www.cptm.sp.gov.br/. Acessado em 31/01/2007.

CRACKNELL, A. P. HAYES, L. W. B. Introduction to remote sensing. 1ed. London: Taylor \& Francis. 1993. 293p.

CROSTA, A.P. Processamento digital de imagens de sensoriamento remoto. Campinas: UNICAMP. 1999. 169p. 
DALMOLIN, Q.; SANTOS, D. R. dos. Sistema Laserscanner: Conceitos e Princípios de Funcionamento. $3^{\circ}$ ed. Curitiba, UFPR, 97p. 2004.

DAVID, R. K. (2005) Desenvolvimento tecnológico na modernização do transporte de passageiros. In: CBTU. (2005) Concurso de Monografia CBTU 2005 - A Cidade nos Trilhos ( $1^{\circ}$ ed). Companhia Brasileira de Trens Urbanos, Rio de Janeiro, RJ.

DNIT - DEPARTAMENTO NACIONAL DE INRA-ESTRUTURA DE TRANSPORTE. Disponível em http://www1.dnit.gov.br/ferrovias/historico.asp Acessado em 07/01/2008.

\begin{tabular}{lccc} 
DNITa - DEPARTAMENTO & NACIONAL DE & INRA-ESTRUTURA & DE \\
\hline TRANSPORTE. & Disponível & & em \\
\hline http://www.dnit.gov.br/noticias/investimentoferroviario. & Acessado & em \\
\hline $07 / 01 / 2008$. & &
\end{tabular}

EHLERS, M. Sensoriamento Remoto para Usuários de SIG-Sistemas sensores e métodos: entre as exigências do usuário e a realidade. Em: Sensoriamento remoto e SIG avançados. Thomas Blaschke e Herman Kux, 2 ed, Oficina de Textos, São Paulo, Br, 2007. 303pgs.

FEITOSA, R. Q.; MATTOS, C.; SANTOS, R. V.; REGO, L. F. G.; PEREIRA, A. A. C. Impacto de técnicas baseadas em conhecimento na análise de imagens de média resolução para mapeamento de desflorestamento na Amazônia. In: XII Simpósio Brasileiro de Sensoriamento Remoto. Goiânia. Anais... São José dos Campos: INPE, 2005. p. 4065 - 4072.

FERNANDEZ, J. F. R. (2006) Projetos em Análise no Estado de São Paulo. Seminário Transporte Interurbano de Passageiros: Desafogando as grandes cidades brasileiras. São Paulo, SP. Disponível em http://www.revistaferroviaria.com.br. Acessado em 10/06/2006.

FERREIRA, E.; DANTAS, A. A. A.; MORAIS, A. R. Exatidão na classificação de fragmentos de matas em imagem do satélite Cbers-CCD, no município de Lavras-MG. In: XIII Simpósio Brasileiro de Sensoriamento Remoto. Florianópolis. Anais... São José dos Campos: INPE, 2007. p. 887-894.

FERREIRA. L.; MURRAY, M. (1997) Modelling rail track deterioration and maintenance: current practices and future needs. Transport Review ,London, 17 (3), 207-221.

FULLER, D. O., WILLIAMSON, R. A., JEFFE, M. IKONOS imagery for mapping transportation infrastructure. International Journal of Remote Sensing, v. 24, № 23, p.4625-4626. 2003.

FUNCATE - FUNDAÇAO DE CIÊNCIA, APLICACCÕES E TECNOLOGIAS ESPACIAIS. Instituto Geológico da Secretaria do Meio Ambiente do Estado 
de São Paulo. Relatório descritivo dos produtos de sensoriamento remoto. São José dos Campos: FUNCATE, 2004. 80 p.

GAMBA, C. T. C; LUCHIARI, A. Avaliação da exatidão de mapeamentos de uso e cobertura da terra obtidos a partir de classificadores baseados na concepção Fuzzy In: XII Simpósio Brasileiro de Sensoriamento Remoto, 2005, Goiânia. Anais... São José dos Campos: INPE, 2005. p. 4073 - 4080.

GOLDCHILD, M. F., HALLMARK, S., NORONHA, V. Infrastructure and Engineering: Overview of Remote Sensing Products and Results. In: Remote Sensing for Transportation, Washington, D.C. Proceedings 29. 2001.

GOMES, A. R.; FREITAS, C. C.; SANT'ANNA, S. J. S.; DUTRA, L. V. Avaliação da aplicação de classificadores pontuais e por regiões para imagem JERS-1 em ambiente SPRING. In: XII Simpósio Brasileiro de Sensoriamento Remoto, 2005, Goiânia. Anais... São José dos Campos: INPE, 2005. p. 4421-4427.

GONZALES, R. C., WOODS, R. E. Processamento de imagens digitais. São Paulo: Editora Edgar Blüncher Ltda. 2000. 509p.

GONZÁLEZ-DUGO, M. P.; MATEOS, L. Spectral vegetation indices for estimating cotton and suggarbeet evapotranspiration. In: American Institute of Physics-AIP Conference. Proceedings, v. 852, p. 115 - 123, 2006.

GUINDON, B.; ZHANG,Y.; DILLABAUGH, C. Landsat urban mapping based on a combined spectral-spatial methodology. IEEE Transactions on Geocience and Remote Sensing, v. 44, o 7, p. 1931 - 1933, 2006.

HANDY, S. Smart growth and the transportation-land use connection: what does the research tell us. In: International Regional Science Review, v.28, no 2, p. 146-167, 2005.

HE, C.; LI, J.; ZHANG, J.; PAN, Y.; CHEN, Y. Dynamic monitor on urban expansion based on a object-oriented approach. In: Geoscience and Remote Sensing Symposium. Proceedings, v 4, p. 2850-2853, 2005.

HEROLD, M.; ROBERTS, D. Spectral characteristics of asphalt road aging and deterioration: implications for remote sensing applications. In: Applied Optics, v. 44, o 20, p. 4327 - 4334, 2005.

INPE - INSTITUTO NACIONAL DE PESQUISAS ESPECIAIS. SPRING 4.2: sistema de ajuda on-line do Spring - manual do usário. Disponível em http://www.dpi.inpe.br/spring/portugues/tutorial. Acesso em 17/01/2007.

INPE - INSTITUTO NACIONAL DE PESQUISAS ESPECIAIS. SPRING 4.2: Manual de Geoprocessamento, disponível em: 
http//www.dpi.inpe.br/spring/portugues/tutorial/introducao_sen.html. Acesso em 20/05/2008.

IWAI, O.; QUINTANILHA, J. A. Utilização de imagens de satélite como ferramenta de auxílio ao planejamento urbano. Revista de Geografía Norte Grande, v. 34, p. 65-82, 2005.

JENSEN, J. R. Remote Sensing of the Environment: An Earth Resource Perspective. $1^{\circ}$ Ed, New Jersey: Prentice-Hall, Inc. 2000. 544p.

JHA, M. K.; KIM, E. Highway route optimization based on accessibility, proximity and land-use changes. Journal of Transportation Enginnering, p.435-439, 2006.

KAYA, S; CURRAN, P. J. Monitoring urban growth on the European side of Istanbul metropolitan area: A case study. International Journal of Apllied Earth Observation and Geoinformation, v. 8, p. 18-25, 2006.

KING, R. L.; O'HARA, C. G. Environmental Streamlining: Overview of Remote Sensing Products and Results. In: Remote Sensing for Transportation, Washington, D.C. Proceedings 29. 2001.

KNIPLING, E. Physical and Physiological Basis for the Reflectance of Visible and Near-Infrared Radition from Vegetation. Remote Sensing of Environment, New York, v. 1, p. 155-159, 1970.

KUX, H. J. H.; ARAÚJO, E. H. G.; DUPONT, H. S. J. B. Remote sensing and GIS techniques for geological and geotechnical problems of urban areas: a case study from Belo Horizonte (Minas Gerais, Brazil). Zeitschrift der Deutschen Gesellschaft für Geowissenschaften, Stuttgart, v.158, no 1, p. 57-65, 2007.

LALIBERTE, A. S.; RANGO, A.; HAVSTAD, K. M.; PARIS, J. F.; BECK, R. F.; McNELLY, R.; GONZALEZ, A. L. Object-oriented image analysis for mapping shrub encroachment from 1937 to 2003 in southtern New Mexico. In: Remote Sensing of Environment, New York, p. 198-210, 2004.

LANDGREBE, D. Multiespectral thematic mapping of land areas, some fundamentals. IEEE Geocience and Remote Sensing Society Newsletter, p. 11 - 15, dezembro, 2007.

LAMBIN, E. F.; LINDERMAN, M. Time series of remote sensing data for land change science. IEEE Transactions on Geocience and Remote Sensing, v. 44, ํo 7, p. $1926-1928,2006$.

LEEUWEN, W. J. D. van; ORR, B. J. Spectral Vegetation Indices and Uncertainty:Insights From a User's Perspective. IEEE Transactions on Geocience and Remote Sensing, v. 44, no 7, p. 1931 - 1933, 2006. 
LILLESAND, T. M.; KIEFER, R. W., CHIPMAN, J. W. Remote sensing and image interpretation. 5ed. New York: John Wiley \& Sons. 2004. 763p.

LONG, H.; ZHAO, Z. Urban road extraction from high-resolution optical sattelite images. International Journal of Remote Sensing, v. 26, no 22, p.4907 - 4921.2005.

LUZ, L. F. da. Os trilhos nas áreas urbanas: conflitos, desafios e oportunidades em dez cidades paulistas. 2006. 255p. Dissertação (Mestrado). Faculdade de Filosofia, Letras e Ciências Humandas da Universidade de São Paulo, São Paulo.

MACHADO, C. A. S. Determinação do índice de acessibilidade do município de Osasco/SP pelo uso de imagens de alta resolução espacial e sig - uma proposta metodológica. 191 p. Dissertação (Mestrado) - EPUSP - Escola Politécnica da Universidade de São Paulo, São Paulo, 2008.

MADEIRA NETTO, J. S.; MENESES, P. R. Sensoriamento Remoto Reflectância dos Alvos Naturais. 1ํㅡ, Brasília: Editora Universidade de Brasília, 2001. 262p.

MADHAVAN, B. B., KUBO S. KURISAKI N., SIVAKUMAR, T. V.L. N. Aappraising the anatomy and spatial growth of the Bangkok Metropolitan area using a vegetation-impervious-soil model through remote sensing. Internationl Journal of Remote Sensig, v. 22, no. 5, p. $789-806$.

MATHER, P. M. Computer Processing of Remotely-Sensed Images. $3^{\circ}$ Ed, Chichester: John Wiley \& Sons Ltd, 2005. 324p.

MEINEL, G.; NEUBERT, M. A comparison of segmentation programs for high-resolution remote sensing data. In: $\mathbf{X X}^{\text {th }}$ ISPRS - International Society for Photogrammetry and Remote Sensing Congress, Istanbul, 2004.

McCORMICK, N.; LAVALLE, C.; KASANKO, M.; DEMICHELI, L.; BARREDO, J. Mapping and modelling the impact of land use planning and management practices on urban and peri-urban landscapes in Europe: the Moland project. In: II GRSS/ISPRS, Joint Workshop on "Data fusion and remote sensing over urban areas". Berlim, Alemanha. Anais. 2003

MELO, D. H. C. T. B. Uso de dados IKONOS II na análise urbana: testes operacionais na zona leste de São Paulo. 2002. 146p. Dissertação (Mestrado) - Instituto Nacional de Pesquisas Espaciais - INPE, São José dos Campos, 2005.

MONTEBELO, L. A.; CASAGRANDE, C. A.; BALLESTER, M. V. R.; VICTORIA, R. L.; CUTOLO, A. P. A. Relação entre uso e cobertura do solo 
e risco de erosão nas áreas de preservação permanente na bacia do ribeirão dos Marins, Piracicaba-SP. In: XII Simpósio Brasileiro de Sensoriamento Remoto, 2005, Goiânia. Anais... São José dos Campos: INPE, 2005. p. $3829-3836$.

MOREIRA, M.A. Fundamentos do Sensoriamento Remoto e Metodologias de Aplicação. 3ํe. ed. Viçosa, Ed. UFV, 2005. 320 p.

MOUTA, L. Reprodutibilidade do exame histológico como critério de validação para métodos de diagnóstico de cárie. 2006. 133p. Dissertação (Mestrado) - Universidade Veiga de Almeida, Rio de Janeiro.

MUCHER, C. A.; STEINNOCHER, K. T.; KRESSLER, F. P.; HEUNKS, C. Land cover characterization and change detection for environment monitoring of pan-Europe. In: International Journal of Remote Sensing, v. $21, n^{\circ} 6$ e 7, p. $1159-1181,2000$.

NÓBREGA, R. A. A.; O`HARA, C. G.; VIJAYARAJ, V.; OLSON, G.; KIM, S. QUINTANILHA, J. A.; BARROS, M. T. L. Extracting and classifying bare soil erosion risk areas in a urban basin using object-oriented technologies, high resolution imagery and elevation data. In: Geographic Information Systems and Water Resources IV AWRA Spring Specialty Conference. Texas, 2006. Proceedings, disponível em http://www.definiens.com/pdf/publications/AWRA 2006.pdf. Acessado em 04/04/2007.

NÓBREGA, R. A. A. Detecção da malha viária na periferia da cidade de São Paulo utilizando imagens de alta resolução espacial e classificação orientada a objetos. 2007. 157p. Tese (Doutorado) - Escola Politécnica da Universidade de São Paulo, São Paulo.

NOVO, E. L. M. Sensoriamento remoto: princípios e aplicações. 2. ed. São Paulo: Edgard Blücher, 1992. 328 p.

OHATA, A. T. Aplicação de Técnicas de Classificação Para Detecção e Mensuração da Expansão Urbana da Região Metropolitana de São Paulo Entre 1991 e 2002. 2004. 100p. Dissertação (Mestrado). Escola Politécnica da Universidade de São Paulo, São Paulo.

QUINTANILHA, J. A.; SILVA, O. F. Identification of urban objects through IKONOS images. In: XII Simpósio Brasileiro de Sensoriamento Remoto, 2005, Goiânia. Anais... São José dos Campos: INPE, 2005. p. 4265-4268.

PEREIRA, W. A. A. (2005) Transporte urbano e qualidade de vida. Seminário Transporte Interurbano de Passageiro. 2005. Disponível em http://www.revistaferroviaria.com.br. Acessado em 10/06/2006. 
PINHO, C. M. D. Análise orientada a objetos de imagens de satélite de alta resolução espacial aplicada à classificação de cobertura do solo no espaço intra-urbano: o caso de São José dos Campos - SP. 2005. 179p. Dissertação (Mestrado) - Instituto Nacional de Pesquisas Espaciais - INPE, São José dos Campos, 2005.

PINHO, C. M. D.; FEITOSA, F. F.; KUX, H. Classificação automática de cobertura de solo urbano em imagem IKONOS: Comparação entre a abordagem pixel-a-pixel e orientada a objetos. In: XII Simpósio Brasileiro de Sensoriamento Remoto, 2005, Goiânia. Anais... São José dos Campos: INPE, 2005. p. 4217-4224.

POCEWICZ, A.; VIERLING, L. A.; LENTILE, L. B.; SMITH, R. View angle effects on relationships between MISR vegetation indices and leaf area index in a recently burned ponderosa pine forest. Remote Sensing of Environment, v. 107, p. 322 - 333, 2007.

PONZONI, F. J. Comportamento Espectral da Vegetação. In: MADEIRA NETTO, J. S.; MENESES, P. R. Sensoriamento Remoto - Reflectância dos Alvos Naturais. 1ํㅡㄹ Brasília: Editora Universidade de Brasília, 2001. $262 p$.

PREFEITURA DE SÃO PAULO. Disponível em http://www9.prefeitura.sp.gov.br/sempla/mm/mapas/indice4 1.pdf. Acessado em 10/05/2007.

PRO, B. H.; HAMMERSCHLAG, R.; MAZZA, P. Energy and land use impacts of sustainable transportation scenarios. In: Journal Cleaner Production, v. 13, p. 1309-1319, 2005.

REDE GLOBO de Televisão. SPTV 1 Ed. 13 de setembro de 2007. Circa $12 \mathrm{~h}$ 15m. Disponível em http://sptv.globo.com/Sptv/0,19125,LPO0-614620070913-301194,00.html. Acessado em 20/09/2007.

REDE GLOBO de Televisão. SPTV 1 Ed. 26 de março 2008. Circa 12h 15m. Disponível em http://sptv.globo.com/Sptv/0,19125,LPO0-6146-20080326318754,00.html . Acessado em 03/04/2008.

REES, G. The Remote Sensing Data Book. 1ํㅡ, Cambridge: Cambridge University Press, 1999. 262p.

SANTER, R.; RAMON, D.; VIDOT, J.; DILLIGEARD, E. A surface reflectance model for aerosol remote sensing over land. International Journal of Remote Sensing, v. 28, no 3-4, p. 736 - 760, 2007.

SANTOS, J. C.; OLIVEIRA, J. R. F.; DUTRA, L. V.; SANT'ANNA, S. J. S.; RENNÓ, C. D. Seleção de atributos usando algoritmos genéticos para classificação de regiões. In: XIII Simpósio Brasileiro de Sensoriamento 
Remoto, 2007, Florianópolis. Anais... São José dos Campos: INPE, 2007. p. 6143-6150.

SCHIEWE, J.; TUFTE, L. O potencial de procedimentos baseados em regiões para a avaliação integrada de dados de SIG e sensoriamento remoto. In: Sensoriamento Remoto e SIG avançados. Ed. BLASCHKE, T.; KUX, H. 2 ed. São Paulo: Oficina de Textos, 2007. p. 56-65.

SCHNEIDER, A.; SETO, K. C.; WEBSTER, D.R. Urban growth in Chengdu, western China: applications of remote sensing to assess planning and policy outcomes. In: Environment and Planning B: Planning and designer, v. 32, p. 323-345, 2005.

SEMINÁRIO Ferrovias - Integração e Crescimento Econômico. 03 dez, 2004. Anais do Seminário Ferrovias - Integração e Crescimento Econômico. Rio de Janeiro. O Globo, 2004.

SHACKELFORD, A. K., DAVIS, C. H. Urban road network extraction from high-resolution multispectral data. In: $2^{\circ}$ GRSS/ISPRS, Berlim, Alemanha. Anais. 2003.

SHORE, W. B. Land-use, transportation and sustainability. Technology in Society, n. 28, p. 27-43, 2006

SIEDENTOP, S.; MEINEL, G. CORINE land cover 2000 in nation-wide and regional of urban land use and land consumption. In: Workshop CORINE land cover 2000, Berlim. Proceedings, p. 162 - 169, 2004.

SILVA, A. M. C. (2005) Conflitos e Rupturas em Torno do Transporte Urbano: A Geohistória dos Trilhos Como Indutor da Urbanização do Brasil no Século XX. In: CBTU. (2005) Concurso de Monografia CBTU 2005 - A Cidade nos Trilhos $\left(1^{\circ}\right.$ ed). Companhia Brasileira de Trens Urbanos, Rio de Janeiro, RJ.

SKIDMORE, A. Accuracy assessment of spatial information. In: Spatial statistics for remote sensing. Ed. STEIN, A.; MEER, F.; GORTE, B. 1.ed. Dordrecht, The Netherlands: Kluwer Academic Publishers, 1999. p. 197-209.

SMITH, H.; RAEMAEKERS, J. Land use pattern and transport in Curitiba. In: Land Use Policy, v. 15, № 33, p. 233-251, 1998.

SOUDANI, K. FRANÇOIS, C.; MAIRE, G. Ie; DANTEC, V. le; DUFRÊNE, E. Comparative analysis of IKONOS, SPOT and ETM+ data for leaf area index estimation in temperature coniferous and deciduous forest stands. Remote Sensing of Environment, v. 102, p. $161-175,2006$.

SOUSA, R. C. A.; KUX, H. J. H. Comportamento espectral e alvos urbanos: simulação com as bandas espectrais do satélite CBERS. In: XII Simpósio 
Brasileiro de Sensoriamento Remoto, 2005, Goiânia. Anais... São José dos Campos: INPE, 2005. p. 1099-1106.

STEINMEIER, C., MUELLER, K. A monitoring concept for detection of land cover change along main traffic routes in Switzerland. IEEE, 2004.

TEOTIA, H.S.; SILVA, I. F.; SANTOS, J. R.; VELOSO JR., J. F.; GONÇALVES, J. L. G. Classificação da cobertura vegetal e capacidade de uso da terra na região do Cariri Velho (Paraíba), através de sensoriamento remoto e geoprocessamento.. In: XI Simpósio Brasileiro de Sensoriamento Remoto, 2003, Belo Horizonte. Anais... São José dos Campos: INPE, 2003. p. $1969-1976$

TÖRMÄ, M. HARMÄ, P. Accuracy of CORINE land cover classification in Northen Finland. In: Geoscience and Remote Sensing Symposium, IGARSS'04. Proceedings, v. 1, p. $227-230,2004$.

TSO, B.; MATHER, P. M. Classification Methods for Remotely Sensed Data. $1^{\circ}$ Ed. London: Taylor \& Francis, 2001. 331p.

ZHU, C.; SHI, W.; PESARESI, M.; LIU, I.; CHEN, X.; KING, B. The recognition of road network fom high-resolution sattelite remotely sensed data using image morphological characteristics. International Journal of Remote Sensing, v. 26, № 24, p.5493 - 5508. 2005.

ZHU, L; TATEISHI, R. Fusion of multisensor multitemporal satellite data for land cover mapping. International Journal of Remote Sensing, v. 27, n.5, p.903-918, 2006. 